\title{
The labour market by education and occupation to 2000
}

Citation for published version (APA):

Researchcentrum voor Onderwijs en Arbeidsmarkt, ROA. (1995). The labour market by education and occupation to 2000: Statistical appendix. Researchcentrum voor Onderwijs en Arbeidsmarkt, Faculteit der Economische Wetenschappen. ROA Reports No. 003BE https://doi.org/10.26481/umarep.1995003BE

Document status and date:

Published: 01/01/1995

DOI:

10.26481/umarep.1995003BE

Document Version:

Publisher's PDF, also known as Version of record

\section{Please check the document version of this publication:}

- A submitted manuscript is the version of the article upon submission and before peer-review. There can be important differences between the submitted version and the official published version of record.

People interested in the research are advised to contact the author for the final version of the publication, or visit the DOI to the publisher's website.

- The final author version and the galley proof are versions of the publication after peer review.

- The final published version features the final layout of the paper including the volume, issue and page numbers.

Link to publication

\footnotetext{
General rights rights.

- You may freely distribute the URL identifying the publication in the public portal. please follow below link for the End User Agreement:

www.umlib.nl/taverne-license

Take down policy

If you believe that this document breaches copyright please contact us at:

repository@maastrichtuniversity.nl

providing details and we will investigate your claim.
}

Copyright and moral rights for the publications made accessible in the public portal are retained by the authors and/or other copyright owners and it is a condition of accessing publications that users recognise and abide by the legal requirements associated with these

- Users may download and print one copy of any publication from the public portal for the purpose of private study or research.

- You may not further distribute the material or use it for any profit-making activity or commercial gain

If the publication is distributed under the terms of Article $25 \mathrm{fa}$ of the Dutch Copyright Act, indicated by the "Taverne" license above, 
Statistical Appendix

The Labour Market by Education and Occupation to 2000

ROA-R-1995/3BE

Research Centre for Education and the Labour Market

Faculty of Economics and Business Administration

University of Limburg

Maastricht, October 1995 
No part of this publication may be reproduced and/or made public by means of printing, photocopying, microfilm, or in any other manner, without the prior written permission of the Director of the Research Centre for Education and the Labour Market. Where any of the data is used the source must be given in every case as: "Research Centre for Education and the Labour Market" or "ROA".

Although the greatest possible care has been taken as regards the contents of this report, no legal rights are implied.

ISBN 90-5321-174-8 


\section{Contents}

Foreword

\section{INFORMATION ON INDUSTRIES}

\section{Figures}

1.1 Expected expansion demand per economic sector, 1995-2000

Tables

$1.1 \quad$ Number of workers per economic sector, average 1993-1994 2

1.2 Percentage of women per economic sector, average 1993-1994 2

1.3 Percentage of young people (15-29 years) and older people (50-64) per economic sector, average 1993-1994

1.4 Percentage of members of ethnic minorities per economic sector, average 1993-1994

1.5 Percentage of workers by educational level and economic sector, average 1993-1994

1.6 Part-time work per economic sector, average 1993-1994

1.7 Self-employment per economic sector, average 1993-1994

1.8 Flexible work per economic sector, average 1993-1994

1.9 Percentage of employees with permanent employment per economic sector, average 1993-1994

1.10 Most important occupational classes per economic sector, average 1993-1994

1.11 Most important types of education per economic sector, average 1993-1994

1.12 Sensitivity to the state of the business cycle per economic sector 11

2 INFORMATION ON OCCUPATIONS

\section{Figures}

2.1 Expected job openings broken down into expansion and replacement demand per occupational sector, 1995-2000

2.1 Number of workers per occupational class, average 1993-1994

2.3 Percentage of young people (15-29 years) and older people (50-64) per occupational class, average 1993-1994

2.4 Percentage of members of ethnic minorities per occupational class, average 1993-1994

2.5 Percentage of workers by educational level per occupational class, average 1993-1994

2.8 Most important economic sectors per occupational class, average 1993-1994

2.9 Opportunities to switch to various economic sub-sectors, per occupational class, average 1993-1994 
2.10 Most important types of education per occupational class, average 1993-1994

2.11 Possibilities of substituting workers with other educational backgrounds per occupational class, average 1993-1994

2.12 Sensitivity to the state of the business cycle per occupational class

2.14 Expected replacement demand per occupational class, 1995-2000

2.15 Expected job openings per occupational class, 1995-2000

\section{INFORMATION ON TYPES OF EDUCATION}

\section{Figures}

3.1 Expected job openings broken down into expansion and replacement demand per educational category, 1995-2000

3.3 Labour market prospects for school-leavers per educational category, in 2000

Tables

3.1 Participation of school-leavers in further education per field of study, 1994

3.5 Percentage of young people (15-29 years) and older people (50-64) per type of education, average 1993-1994

3.6 Percentage of members of ethnic minorities per type of education, average 1993-1994

3.7 Percentage of working school-leavers who are from ethnic minorities per field of study, 1994

Part-time work per type of education, average 1993-1994

Self-employment per type of education, average 1993-1994

Percentage of employees with permanent employment per type

of education, average 1993-1994

3.13 Percentage of working school-leavers in permanent employment per field of study, 1994

3.14 Average gross monthly wage of working school-leavers per field of study, 1994

3.15 Most important occupational classes per type of education, average 1993-1994

3.16 Opportunities to switch to other occupational groups at a matching or higher function level per type of education, average 1993-1994

3.17 Most important economic sectors per type of education, average 1993-1994

3.18 Opportunities to switch to other economic sub-sectors per type of education, average 1993-1994

3.19 Overview of types of education facing (strong) competition on the labour market 
on entering the labour market per field of study, 1994

Percentage of school-leavers registered as unemployed

per field of study, 1994

3.23 Percentage of under-utilization per type of education, 1994

3.24 Under-utilization of working school-leavers per field of study, 1994

3.25 Percentage of working school-leavers with a job in the field in which they trained per field of study, 1994

3.26 Expected flow of school-leavers entering the labour market per type of education, 1995-2000

3.27 Expected expansion demand per type of education, 1995-2000

3.28 Expected replacement demand per type of education, 1995-2000

Appendix A

$\begin{array}{ll}\text { A.1 } & \text { Economic sectors } \\ \text { A.2 } & \text { Occupational classes } \\ \text { A.3 } & \text { Types of education }\end{array}$

180

A.3 Types of education 183

de a qualitative characterizatior ormation also includes an indic o the period 1990-1994, but th e analyses by types of educatic ily been possible to use the tr changes in the share of the es for changes in the number

t data as regards the labour fol sbevolking, or EBB) of Statistics information, the data presente 994. To ensure that individual d a restriction on the publicat ; for categories containing less

in school-leavers, presented in irveys, the 'RUBS' survey (I

itermediate updates of the Statistici hich these characterizations and $t$ hodiek van het informatiesysteem stem on education and the labour $n$ 
Schoolverlaters), which records the flows of school-leavers and their des labour market, and the 'Higher Vocational Education Monitor' (HBO Monitor) survey school-leavers approximately 10 months and 18 months, respectively, left the education system. The information presented in this Statistical Appenc labour market situation, in 1994, of those graduating in the 1992-1993 school restriction on this school-leaver data which prevents us publishing information with less than 25 respondents.

The following abbreviations have been used in tables referring to levels of edı

LGSE Lower General Secondary Education

PVE Preparatory Vocational Education

MAVO, onderbc

SIVE Shorter Intermediate Vocational Education

IVE Intermediate Vocational Education

HGSE Higher General Secondary Education (SGSE + PUE)

SGSE Senior General Secondary Education

PUE Pre-University Education

HVE Higher Vocational Education

UE University Education

VBO

$\mathrm{KMBO}$

MBO/LLW

HAVONWO bo

HAVO

WWO

$\mathrm{HBO}$

WO

Many of the courses in Intermediate Vocational Education (IVE) include training in the same subject. However Technical laboratory, Tourism and recre fiscal and Social and cultural, have no parallel apprenticeship courses.

Other abbreviations and symbols used include:

apprent.

apprenticeship training.

qualitative charact.

qualitative characterization.

the data could not be published because of the restrictions.

the characterization or trend is not known.

The central concepts which have been used are defined at the end of the $n$ references to the publications in which further information can be found. At Statistical Appendix there is an overview of the economic sectors, occupatio types of education as these have been defined in these reports, with the asso codes. 
1 INFORMATION ON INDUSTRIES 
Figure 1.1

Expected expansion demand per economic sector, 1995-2000 (average annual percentage)

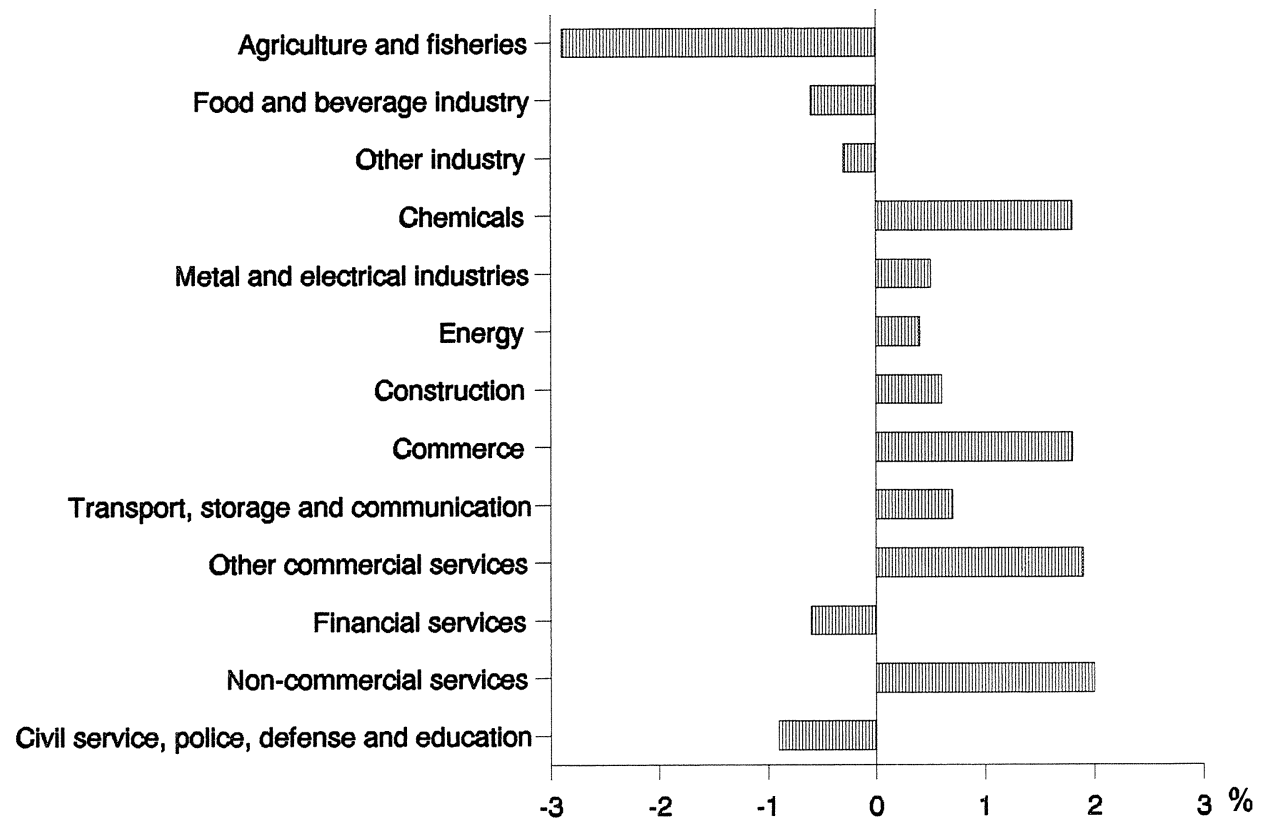

Source: ROA 
Table 1.1

Number of workers per economic sector, average 1993-1994

\begin{tabular}{lcc}
\hline Economic sector & number of workers & $\begin{array}{c}\text { trend } \\
1990-' 94\end{array}$ \\
\hline Agriculture and fisheries & 231,500 & falling \\
Food and beverage industry & 157,500 & constant \\
Other industry & 242,500 & constant \\
Chemicals & 125,000 & constant \\
Metal and electrical industries & 491,000 & constant \\
Energy & 65,000 & constant \\
Construction & 428,500 & constant \\
Commerce & 822,000 & constant \\
Transport, storage and communication & 373,500 & constant \\
Other commercial services & 756,500 & constant \\
Financial services & 207,500 & constant \\
Non-commercial services & 937,000 & constant \\
Civil service, police, defense and education & 609,500 & constant \\
\hline
\end{tabular}

Source: CBS/ROA

Table 1.2

Percentage of women per economic sector, average 1993-1994

\begin{tabular}{|c|c|c|c|}
\hline Economic sector & $\%$ & $\begin{array}{l}\text { qualitative } \\
\text { charact. }\end{array}$ & $\begin{array}{l}\text { trend } \\
1990-' 94\end{array}$ \\
\hline Agriculture and fisheries & 23 & low & constant \\
\hline Food and beverage industry & 27 & average & - \\
\hline Other industry & 25 & low & constant \\
\hline Chemicals & 17 & low & constant \\
\hline Metal and electrical industries & 14 & low & - \\
\hline Energy & 14 & low & - \\
\hline Construction & 10 & very low & rising \\
\hline Commerce & 42 & average & constant \\
\hline Transport, storage and communication & 21 & low & rising \\
\hline Other commercial services & 39 & average & - \\
\hline Financial services & 44 & average & constant \\
\hline Non-commercial services & 69 & high & constant \\
\hline Civil service, police, defense and education & 43 & average & - \\
\hline
\end{tabular}

Source: CBS/ROA 
Table 1.3

Percentage of young people (15-29 years) and older people (50-64) per economic sector, average 1993-1994

\begin{tabular}{|c|c|c|c|c|c|c|}
\hline \multirow[t]{2}{*}{ Economic sector } & \multicolumn{3}{|c|}{ young people } & \multicolumn{3}{|c|}{ older people } \\
\hline & $\%$ & $\begin{array}{l}\text { qualitative } \\
\text { charact. }\end{array}$ & $\begin{array}{l}\text { trend } \\
\text { 1990-'94 }\end{array}$ & $\%$ & $\begin{array}{l}\text { qualitative } \\
\text { charact. }\end{array}$ & $\begin{array}{l}\text { trend } \\
\text { 1990-'94 }\end{array}$ \\
\hline Agriculture and fisheries & 30 & average & constant & 25 & very high & falling \\
\hline Food and beverage industry & 35 & average & constant & 14 & average & constant \\
\hline Other industry & 32 & average & falling & 15 & average & - \\
\hline Chemicals & 25 & average & falling & 17 & average & - \\
\hline Metal and electrical industries & 28 & average & falling & 15 & average & - \\
\hline Energy & 15 & low & falling strongly & 21 & high & rising \\
\hline Construction & 32 & average & constant & 15 & average & constant \\
\hline Commerce & 41 & high & constant & 13 & average & - \\
\hline Transport, storage and communication & 28 & average & falling & 13 & average & constant \\
\hline Other commercial services & 38 & high & constant & 11 & low & - \\
\hline Financial services & 32 & average & falling & 12 & average & rising \\
\hline Non-commercial services & 27 & average & falling & 12 & average & rising \\
\hline Civil serv., police, defense and education & 19 & low & falling & 17 & average & rising \\
\hline
\end{tabular}

Source: CBS/ROA

Table 1.4

Percentage of members of ethnic minorities per economic sector, average 1993-1994

\begin{tabular}{llll}
\hline Economic sector & $\%$ & qualitative & $\begin{array}{c}\text { trend } \\
\text { charact. }\end{array}$ \\
& & log2-'94 \\
Agriculture and fisheries & 2 & low & rising strongly \\
Food and beverage industry & 7 & very high & - \\
Other industry & 4 & average & rising \\
Chemicals & 5 & average & - \\
Metal and electrical industries & 5 & average & rising \\
Energy & $\%$ & average & - \\
Construction & 2 & low & rising strongly \\
Commerce & 3 & average & rising \\
Transport, storage and communication & 3 & average & - \\
Other commercial services & 4 & average & rising \\
Financial services & 3 & average & - \\
Non-commercial services & 3 & average & - \\
Civil service, police, defense and education & 3 & average & rising
\end{tabular}

Source: CBS/ROA

- The percentage relates to the members of those ethnic minorities which fall under the 'Promotion of Balanced Employment Participation by Members of Ethnic Minorities Act' (Wet Bevordering Evenredige Arbeidsdeelname Allochtonen, WBEAA): i.e., those from Aruba, the Dutch Antilles, Ethiopia, Iraq, Iran, the former Yugoslavia, Morocco, Somalia, Surinam, Turkey and Vietnam. 


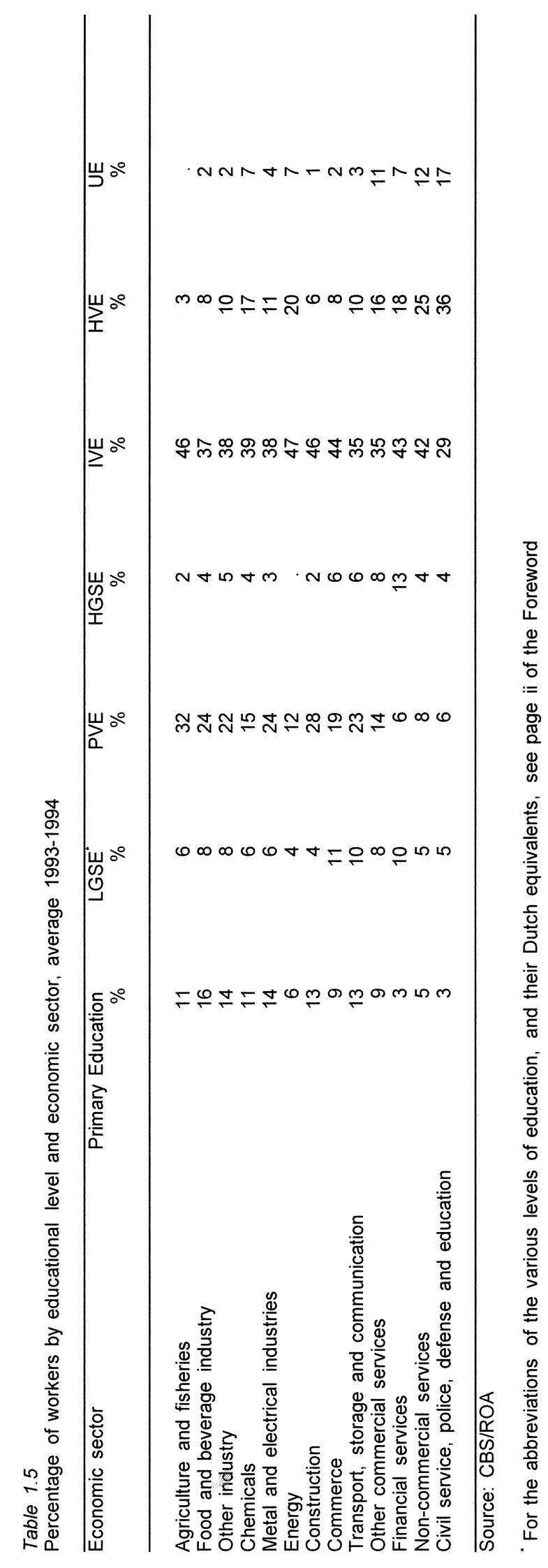


Table 1.6

Part-time work per economic sector, average 1993-1994

\begin{tabular}{|c|c|c|c|}
\hline Economic sector & $\%$ & $\begin{array}{l}\text { qualitative } \\
\text { charact. }\end{array}$ & $\begin{array}{l}\text { trend } \\
1992-94\end{array}$ \\
\hline $\begin{array}{l}\text { Agriculture and fisheries } \\
\text { Food and beverage industry } \\
\text { Other industry } \\
\text { Chemicals } \\
\text { Metal and electrical industries } \\
\text { Energy } \\
\text { Construction } \\
\text { Commerce } \\
\text { Transport, storage and communication } \\
\text { Other commercial services } \\
\text { Financial services } \\
\text { Non-commercial services } \\
\text { Civil service, police, defense and education }\end{array}$ & $\begin{array}{r}20 \\
14 \\
16 \\
8 \\
9 \\
6 \\
9 \\
26 \\
15 \\
27 \\
18 \\
50 \\
25\end{array}$ & $\begin{array}{l}\text { average } \\
\text { low } \\
\text { average } \\
\text { low } \\
\text { low } \\
\text { low } \\
\text { low } \\
\text { average } \\
\text { low } \\
\text { average } \\
\text { average } \\
\text { high } \\
\text { average }\end{array}$ & $\begin{array}{l}\text { constant } \\
\text { rising } \\
\text { rising } \\
\text { falling } \\
- \\
\text { - } \\
\text { rising } \\
\text { rising } \\
\text { rising } \\
\text { rising } \\
\text { rising } \\
\text { constant } \\
\text { rising }\end{array}$ \\
\hline
\end{tabular}

Source: CBS/ROA

Table 1.7

Self-employment per economic sector, average 1993-1994

\begin{tabular}{|c|c|c|c|}
\hline Economic sector & $\%$ & $\begin{array}{l}\text { qualitative } \\
\text { charact. }\end{array}$ & $\begin{array}{l}\text { trend } \\
1992-' 94\end{array}$ \\
\hline Agriculture and fisheries & 63 & very high & constant \\
\hline Food and beverage industry & 4 & very low & - \\
\hline Other industry & 7 & low & falling \\
\hline Chemicals & & - & - \\
\hline Metal and electrical industries & 3 & very low & rising strongly \\
\hline Energy & & - & - \\
\hline Construction & 12 & average & rising strongly \\
\hline Commerce & 15 & average & rising strongly \\
\hline Transport, storage and communication & 5 & very low & rising \\
\hline Other commercial services & 20 & high & rising \\
\hline Financial services & 3 & very low & falling strongly \\
\hline Non-commercial services & 9 & average & rising \\
\hline Civil service, police, defense and education & 1 & very low & falling strongly \\
\hline
\end{tabular}

Source: CBS/ROA

- Including people working in the business or practice of their spouse or parents, and freelancers etc. 
Table 1.8

Flexible work per economic sector, average 1993-1994

\begin{tabular}{llll}
\hline Economic sector & $\%$ & $\begin{array}{l}\text { qualitative } \\
\text { charact. }\end{array}$ & $\begin{array}{l}\text { trend } \\
1992-' 94\end{array}$ \\
\hline Agriculture and fisheries & & average & - \\
Food and beverage industry & 8 & average & - \\
Other industry & 9 & average & rising \\
Chemicals & 4 & low & rising strongly \\
Metal and electrical industries & 4 & low & - \\
Energy & 3 & - & - \\
Construction & 7 & low & rising strongly \\
Commerce & 6 & average & - \\
Transport, storage and communication & 9 & average & constant \\
Other commercial services & 4 & low & rising strongly \\
Financial services & 8 & average & - \\
Non-commercial services & 5 & low & rising strongly \\
Civil service, police, defense and education & & & \\
\end{tabular}

Source: CBS/ROA

Table 1.9

Percentage of employees with permanent employment per economic sector, average 1993-1994

\begin{tabular}{llll}
\hline Economic sector & $\%$ & qualitative & $\begin{array}{c}\text { trend } \\
\text { charact. }\end{array}$ \\
& & & $1992-94$ \\
Agriculture and fisheries & & & - \\
Food and beverage industry & 80 & very low & - \\
Other industry & 91 & low & - \\
Chemicals & 93 & average & average \\
Metal and electrical industries & 94 & high & constant \\
Energy & 96 & high & constant \\
Construction & 96 & low & constant \\
Commerce & 96 & average & constant \\
Transport, storage and communication & 92 & very low & constant \\
Other commercial services & 94 & high & constant \\
Financial services & 89 & low & constant \\
Non-commercial services & 96 & 92 & constant \\
Civil service, police, defense and education & 95 & & \\
\hline
\end{tabular}

Source: CBS/ROA 
Table 1.10

Most important occupational classes per economic sector, average 1993-1994

\begin{tabular}{lll}
\hline Economic sector & $\%$ & trend \\
& $1990-94$ \\
\hline
\end{tabular}

Agriculture and fisheries

Farmers

Agricultural workers

50

35 falling

Food and beverage industry

Food and beverage processors

Bakers and bakery personnel

Freight handlers and packers

Sales assistants

Managers and supervisors in manufacturing

Purchasing and sales clerks

falling

Other industry

Printing industry production workers

Managers and supervisors in manufacturing

Carpenters and woodworkers

Purchasing and sales clerks

constant

falling

rising

rising strongly

Chemicals

Chemical process workers

Managers and supervisors in manufacturing

Ceramic and glass industry production workers

Purchasing and sales clerks

Technical analysts and laboratory assistants

Freight handlers and packers

falling

rising strongly

rising

rising

Metal and electrical industries

Managers and supervisors in manufacturing

Welders and engineering workers

Lathe operators and metal workers

Purchasing and sales clerks

Metal-processing machine operators

constant

rising strongly

falling

falling

Energy

Managers and supervisors in manufacturing

Purchasing and sales clerks

Electricians and telecommunication servicemen

Book-keepers and bank employees

\section{Construction}

Carpenters and woodworkers

Managers and supervisors in manufacturing

Bricklayers and plasterers

Plumbers

Road construction workers and pipelayers

Electricians and telecommunication servicemen

Painters

-

falling

rising strongly
falling
-
falling

rising strongly

rising strongly

constant

falling 
Table 1.10 (continued)

Most important occupational classes per economic sector, average 1993-1994

Economic sector $\%$ trend

1990-'94

\section{Commerce}

Sales assistants

Shopkeepers, retail and wholesale staff

Book-keepers and bank employees

Commercial representatives, buyers and branch managers

Purchasing and sales clerks

rising

falling

rising

falling

falling

$-$

Porters, cleaners and domestics

Managers and supervisors in manufacturing

Book-keepers and bank employees

Hotel and catering owners and supervisors

Programmers and system analysts

falling
rising
rising
-
-

rising

rising strongly

rising

falling

constant

rising strongly

constant

Purchasing and sales clerks

Primary and special education teachers

Police, fire and security officers

$\begin{aligned} 12 & \text { rising strongly } \\ 11 & \text { constant } \\ 5 & -\end{aligned}$

Source: CBS/ROA 
Table 1.11

Most important types of education per economic sector, average 1993-1994

Economic sector $\%$ trend

1992-'94

Agriculture and fisheries

IVE Agriculture and the natural environment

PVE Agriculture

Primary Education

PVE Community care, hotel and catering

Lower General Secondary Education

rising

falling strongly

falling

rising strongly

Food and beverage industry

Primary Education

IVE Food technology

Lower General Secondary Education

IVE Retail

PVE Community care, hotel and catering

$\begin{aligned} 17 & \text { falling strongly } \\ 12 & \text { falling } \\ 7 & - \\ 6 & \text { rising strongly }\end{aligned}$

Other industry

Primary Education

IVE Printing technology

Lower General Secondary Education

PVE Construction trades

IVE Retail

falling strongly

rising strongly

falling strongly

hemicals

Primary Education

Lower General Secondary Education

IVE Process technologies

falling

Metal and electrical industries

Primary Education

PVE Mechanical trades

IVE Metalworking

IVE Electrical technology

Lower General Secondary Education

IVE Mechanical engineering

falling

falling

rising

Energy

IVE Electrical technology

IVE Mechanical engineering

Primary Education

IVE Retail

falling

falling

Construction

IVE Construction technology

PVE Construction trades

Primary Education

IVE Electrical technology

falling

falling 
Table 1.11 (continued)

Most important types of education per economic sector, average 1993-1994

Economic sector $\quad \% \quad$ trend

1992-'94

\section{Commerce}

IVE Retail

Lower General Secondary Education

Primary Education

Higher General Secondary Education

PVE Community care, hotel and catering

Transport, storage and communication

Primary Education

Lower General Secondary Education

IVE Transport and harbour

Higher General Secondary Education

PVE Transport and harbour

Other commercial services

Primary Education

Higher General Secondary Education

Lower General Secondary Education

IVE Community care

\section{Financial services}

Higher General Secondary Education Lower General Secondary Education IVE Retail

\section{Non-commercial services}

IVE Nursing and paramedical services IVE Community care

HVE Nursing and paramedical services

HVE Social and cultural

11
8

6

constant

falling

Civil service, police, defense and education

HVE Teacher training

IVE Police, fire and defense

Lower General Secondary Education

constant

constant

falling

constant

falling

falling

rising

rising

rising

constant

Source: CBS/ROA 
Table 1.12

Sensitivity to the state of the business cycle per economic sector

\begin{tabular}{lcl}
\hline Economic sector & $\begin{array}{c}\text { sensitivity } \\
\text { to business cycle }\end{array}$ & $\begin{array}{l}\text { qualitative } \\
\text { charact. }\end{array}$ \\
\hline Agriculture and fisheries & 0.33 & very low \\
Food and beverage industry & 0.68 & average \\
Other industry & 0.95 & average \\
Chemicals & 1.03 & high \\
Metal and electrical industries & 1.39 & high \\
Energy & 1.13 & very high \\
Construction & 1.74 & average \\
Commerce & 0.48 & average \\
Transport, storage and communication & 0.72 & low \\
Other commercial services & 0.46 & average \\
Financial services & 0.59 & low \\
Non-commercial services & 0.41 & low \\
Civil service, police, defense and education & 0.47 & \\
\hline
\end{tabular}

\section{Source: ROA}

Table 1.13

Expected expansion demand per economic sector, 1995-2000

\begin{tabular}{lrrll}
\hline Economic sector & number & $\begin{array}{c}\text { total } \\
\%\end{array}$ & $\begin{array}{l}\text { average } \\
\text { annual \% }\end{array}$ & $\begin{array}{l}\text { qualitative } \\
\text { charact. }\end{array}$ \\
\hline Agriculture and fisheries & $-38,300$ & -14 & -2.9 & very low \\
Food and beverage industry & $-4,900$ & -3 & -0.6 & low \\
Other industry & $-3,000$ & -1 & -0.3 & average \\
Chemicals & 11,400 & 10 & 1.8 & high \\
Metal and electrical industries & 9,000 & 2 & 0.5 & average \\
Energy & 1,300 & 2 & 0.4 & average \\
Construction & 13,000 & 3 & 0.6 & average \\
Commerce & 92,200 & 10 & 1.8 & high \\
Transport, storage and communication & 12,800 & 4 & 0.7 & average \\
Other commercial services & 102,400 & 10 & 1.9 & high \\
Financial services & $-5,600$ & -3 & -0.6 & low \\
Non-commercial services & 87,700 & 10 & 2.0 & high \\
Civil service, police, defense and education & $-35,100$ & -5 & -0.9 & low \\
& & & &
\end{tabular}

Source: ROA 
2 INFORMATION ON OCCUPATIONS 
...... 
Figure 2.1

Expected job openings, broken down into expansion and replacement demand per occupational sector, 1995-2000 (average annual percentage)

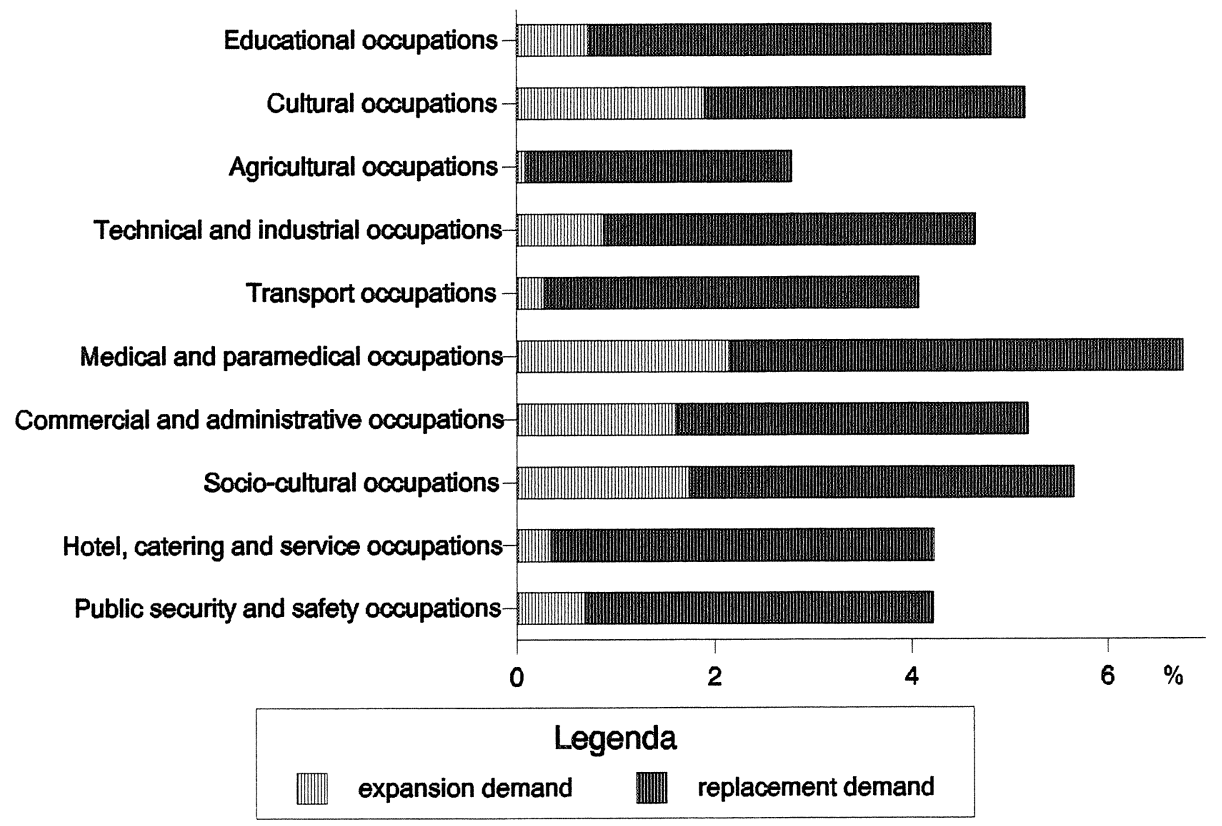

Source: ROA 
Table 2.1

Number of workers per occupational class, average 1993-1994

Occupational class number of workers trend

1990-'94

\section{Educational occupations}

Primary and special education teachers

Secondary and tertiary education teachers

School principals and other higher educational professions

11,500

constant

Trainers, sports officials and sports professionals

rising

rising

\section{Cultural occupations}

Translators and other literary professions

Pastoral vocations

6,500

7,000

34,500

Photographers and designers

32,500

rising

Visual and performing artists

constant

rising

Agricultural occupations

Agricultural workers

Farmers

117,500

124,500

constant

Agricultural and environmental engineers

falling

falling

Technical and industrial occupations

Forklift drivers

Construction machine operators

31,500

Managers and supervisors in manufacturing

Technical and medical representatives

325,000

20,000

Technical draughtsmen

30,000

Technical analysts and laboratory assistants

27,000

55,000

Scientific researchers, technicians and statisticians

40,000

Food and beverage processor

Bakers and bakery personne

Textile production workers

Upholsterers, shoemakers and leatherworkers

Clothing production workers and sailmakers

Wood, paper and cardboard product workers

Carpenters and woodworkers

Printing industry production workers

Chemical process workers

Smelter workers and drilling hands

Metal-processing machine operators

Welders and engineering workers

Lathe operators and metal workers

Machinery mechanics and instrument makers

Automobile mechanics

Intermediate mechanical engineers

Higher mechanical engineers

Electrical product assembly workers and quality controllers

20,500

8,000

19,000

16,500

10,500

123,000

46,000

25,500

12,000

33,500

58,000

66,500

65,500

42,500

12,000

12,500

25,500

Electricity and gas supply workers

3,000

98,000

Intermediate electrical engineers

Higher electrical engineers

4,500

19,000

Ceramic and glass industry production workers

Bricklayers and plasterers

Glaziers and concreting hands

44,500

23,500

30,500

40,500

63,000

27,000

Construction supervisors

27,000
36,500

rising

constant

constant

rising strongly

falling

falling

falling

falling

falling

constant

falling

falling

constant

falling

constant

falling

falling

constant

falling

constant

constant

constant

falling

constant

falling

constant

constant

constant

falling

constant

constant

constant

falling

falling

rising

rising 
Table 2.1 (continued)

Number of workers per occupational class, average 1993-1994

Occupational class number of workers trend

Transport occupations

Freight handlers and packers

Fishermen and gamekeepers

Sailors, deckhands and engine-room workers

Ship's officers and marine inspectors

Drivers and conductors

Pilots and transport and freight supervisors

120,500

3,000

5,500

9,000

176,000

21,000

107,000

123,000

21,500

17,500

27,000

31,000

27,000

40,500

3,000

5,000

etinary surgeons

Dentists and dental specialists

Commercial and administrative occupations

Senior finance and sales managers

Mail clerks and postal workers

93,500

37,500

12,000

Datatypists and computer operators

Administrative supervisors

27,000

138,000

19,500

Library and archive assistants

Book-keepers and bank employees

351,500

358,000

77,000

Telephonists, receptionists and pollsters

Programmers and system analysts

124,500

62,500

Accountants and economists

268,500

162,500

$\begin{array}{lr}\text { Commercial representatives, buyers and branch managers } & 134,500 \\ \text { Civil servants (public administration) } & 26,500\end{array}$

Civil servants (public administration)

30,500

Legal professionals

\section{Socio-cultural occupations}

Journalists and announcers

Librarians and archivists

Personnel officers and vocational advisors

Community workers and probation officers

Social scientists

Public relations specialists

34,000

17,000

32,500

68,000

22,500

12,000

falling

rising

constant

rising

rising

falling

constant

rising

constant

constant

constant

falling

falling

falling strongly

constant

constant

constant

rising

constant

constant

rising

rising

constant

constant

constant

constant

rising

rising

rising

constant

falling

Hotel, catering and service occupations

Cooks, waiters and kitchen workers

Hotel and catering owners and supervisors

29,500

60,500

constant

149,000

120,500

34,500 constant
Heriatric help and kindergarten
Hairdressers and beauticians 
Table 2.1 (continued)

Number of workers per occupational class, average 1993-1994

Occupational class

number of workers

trend

1990-'94

Public security and safety occupations

Police, fire and security officers

Military professionals

35,000

constant

constant

Source: CBS/ROA 
Table 2.2

Percentage of women per occupational class, average 1993-1994

\begin{tabular}{llll}
\hline Occupational class & $\%$ & $\begin{array}{l}\text { qualitative } \\
\text { charact. }\end{array}$ & $\begin{array}{c}\text { trend } \\
1990-' 94\end{array}$ \\
\hline
\end{tabular}

\section{Educational occupations}

$\begin{array}{ll}\text { high } & \text { rising } \\ \text { average } & - \\ \text { average } & \text { rising } \\ \text { average } & -\end{array}$

Primary and special education teachers

Secondary and tertiary education teachers

School principals and other higher educational professions 33

Trainers, sports officials and sports professionals

\section{Cultural occupations}

Translators and other literary professions

Pastoral vocations

Photographers and designers

Visual and performing artists

\section{Agricultural occupations}

Agricultural workers

Farmers

Agricultural and environmental engineers

\section{Technical and industrial occupations}

Forklift drivers

Construction machine operators

Managers and supervisors in manufacturing

Technical and medical representatives

Technical draughtsmen

Technical analysts and laboratory assistants

Scientific researchers, technicians and statisticians

Food and beverage processors

Bakers and bakery personnel

Textile production workers

Upholsterers, shoemakers and leatherworkers

Clothing production workers and sailmakers

Wood, paper and cardboard product workers

Carpenters and woodworkers

Printing industry production workers

Chemical process workers

Smelter workers and drilling hands

Metal-processing machine operators

Welders and engineering workers

Lathe operators and metal workers

Machinery mechanics and instrument makers

Automobile mechanics

Intermediate mechanical engineers

Higher mechanical engineers

Electrical product assembly workers and quality controllers

Electricity and gas supply workers

Electricians and telecommunication servicemen

Intermediate electrical engineers

Higher electrical engineers

Ceramic and glass industry production workers

Bricklayers and plasterers

Glaziers and concreting hands

Painters

Plumbers

Road construction workers and pipelayers

Construction supervisors

Architects and construction engineers

$\begin{array}{ll}\text { high } & - \\ \text { very low } & - \\ \text { average } & \text { falling } \\ \text { average } & \text { falling }\end{array}$

$\begin{array}{ll}\text { average } & \text { falling } \\ \text { low } & \text { rising strongly } \\ \text { low } & -\end{array}$

very low -

$\begin{array}{ll}\text { very low } & \text { row } \\ \text { low } & \text { rising strongly }\end{array}$

low -

very low -

average rising

low falling

low -

low -

average -

very high constant

very low -

very low -

very low -

very low

very low

very low

very low

very low

very low

-

average

very low

very low

very low

very low

very low

very low

very low

very low

very low

very low

very low

very low 
Table 2.2 (continued)

Percentage of women per occupational class, average 1993-1994

\begin{tabular}{llll}
\hline Occupational class & $\%$ & $\begin{array}{l}\text { qualitative } \\
\text { charact. }\end{array}$ & $\begin{array}{c}\text { trend } \\
1990-' 94\end{array}$ \\
\hline
\end{tabular}

Transport occupations

Freight handlers and packers

Fishermen and gamekeepers

Sailors, deckhands and engine-room workers

Ship's officers and marine inspectors

Drivers and conductors

Pilots and transport and freight supervisors

27

very low

very low

very low

6 very low

very low

\section{Medical and paramedical occupations}

Nursing staff

Student nurses and home nursing personnel

Doctors', dentists' and vetinary assistants

Pharmacy assistants and opticians

Paramedics and related functions

Physiotherapists and occupational therapists

Medical and biological laboratory analysts

Physicians, medical specialists and pharmacists

Vetinary surgeons

Dentists and dental specialists

Commercial and administrative occupations

Senior finance and sales managers

Mail clerks and postal workers

Datatypists and computer operators

Administrative supervisors

Secretaries and typists

Library and archive assistants

Book-keepers and bank employees

Purchasing and sales clerks

Telephonists, receptionists and pollsters

Programmers and system analysts

Accountants and economists

Sales assistants

Shopkeepers, retail and wholesale staff

Commercial representatives, buyers and branch managers

Civil servants (public administration)

Legal professionals

$\begin{array}{rll}79 & \text { very high } & \text { constant } \\ 87 & \text { very high } & \text { constant } \\ 99 & \text { very high } & - \\ 84 & \text { very high } & - \\ 72 & \text { high } & - \\ 62 & \text { high } & \text { constant } \\ 70 & \text { high } & - \\ 37 & \text { average } & \text { rising } \\ . & \text { low } & - \\ . & \text { low } & -\end{array}$

\section{Socio-cultural occupations}

Journalists and announcers

Librarians and archivists

Personnel officers and vocational advisors

Community workers and probation officers

Social scientists

Public relations specialists
17

23

57

40

98

63

56

52

76

12

19

63

26

21

38

$\begin{array}{ll}\text { low } & - \\ \text { low } & - \\ \text { high } & - \\ \text { average } & \text { rising strongly } \\ \text { very high } & \text { constant } \\ \text { high } & - \\ \text { high } & \text { constant } \\ \text { high } & - \\ \text { very high } & \text { constant } \\ \text { low } & - \\ \text { low } & - \\ \text { high } & - \\ \text { average } & \text { rising } \\ \text { low } & \text { rising } \\ \text { low } & \text { rising } \\ \text { average } & \text { rising }\end{array}$

Hotel, catering and service occupations

Cooks, waiters and kitchen workers

Hotel and catering owners and supervisors

Porters, cleaners and domestics

Geriatric help and kindergarten staff

Hairdressers and beauticians
43

63

54

67

52

25

$\begin{array}{ll}\text { average } & - \\ \text { high } & \text { rising } \\ \text { high } & \text { rising } \\ \text { high } & \text { rising } \\ \text { high } & - \\ \text { low } & \text { falling }\end{array}$

high

average

high

very high

very high constant
-
-
- rising
-

constant

onstant

ising falling

constant 
Table 2.2 (continued)

Percentage of women per occupational class, average 1993-1994

Occupational class

$\%$

qualitative

trend

charact.

1990-'94

Public security and safety occupations

Police, fire and security officers

Military professionals

rising

Source: CBS/ROA 


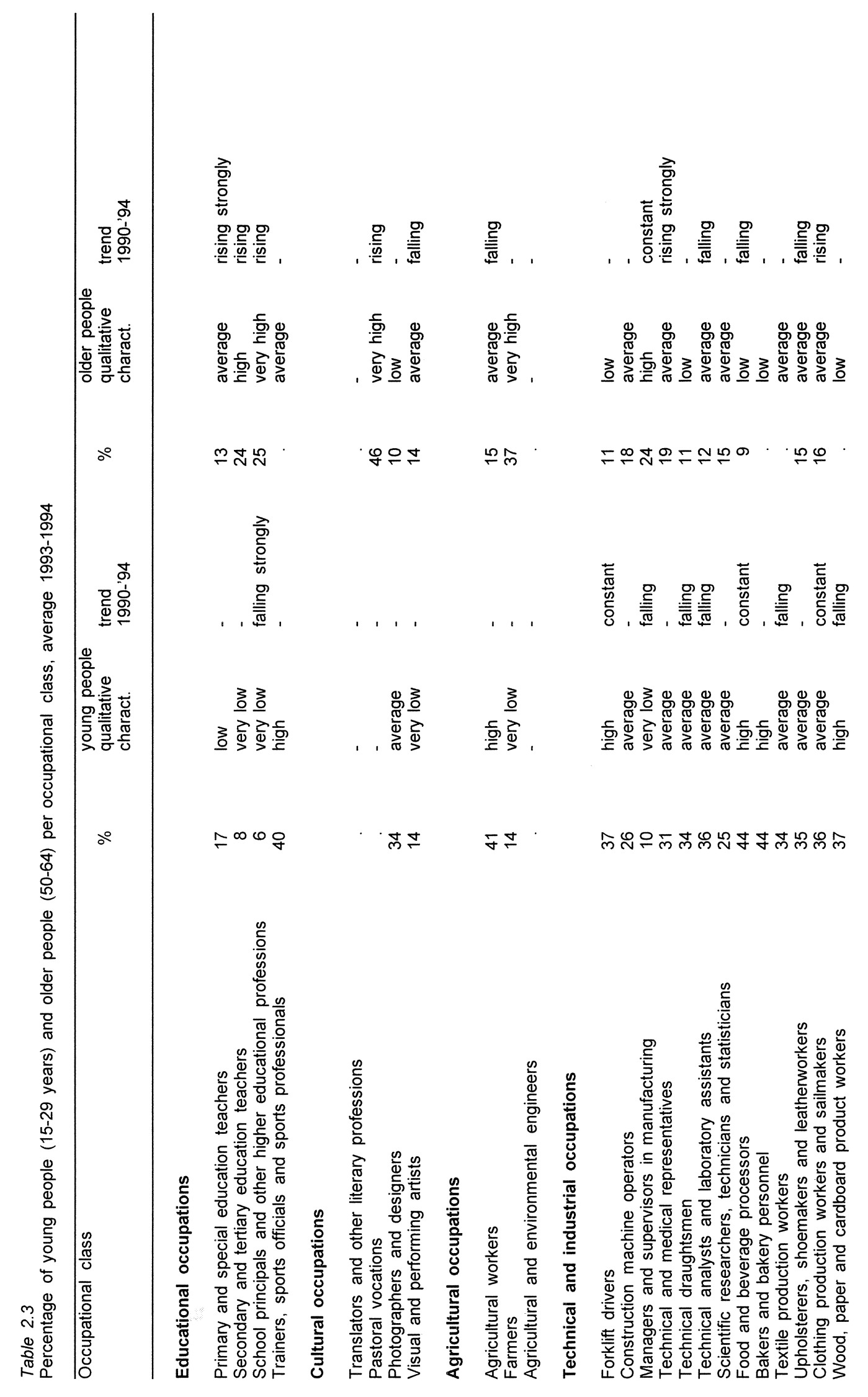




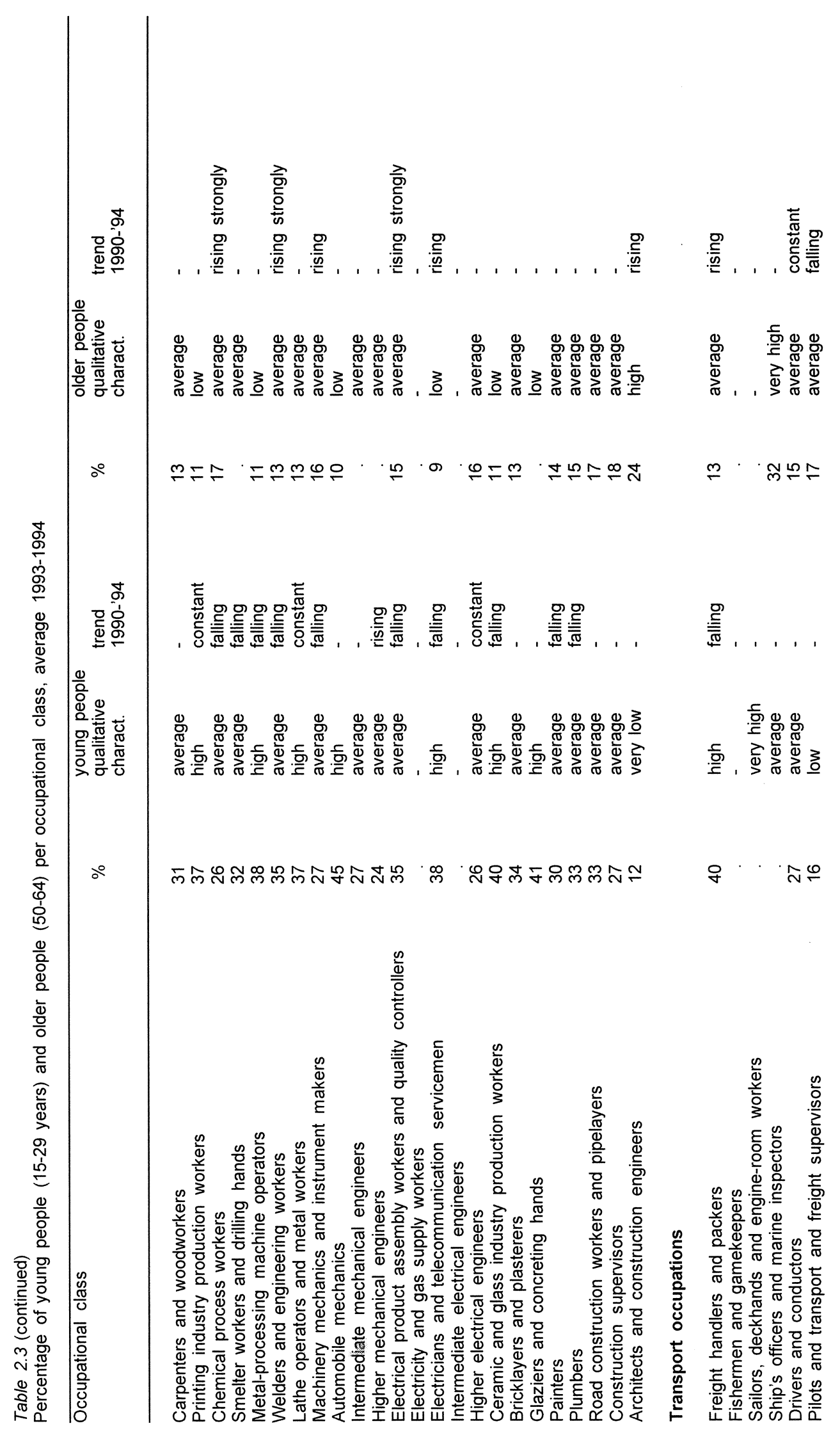




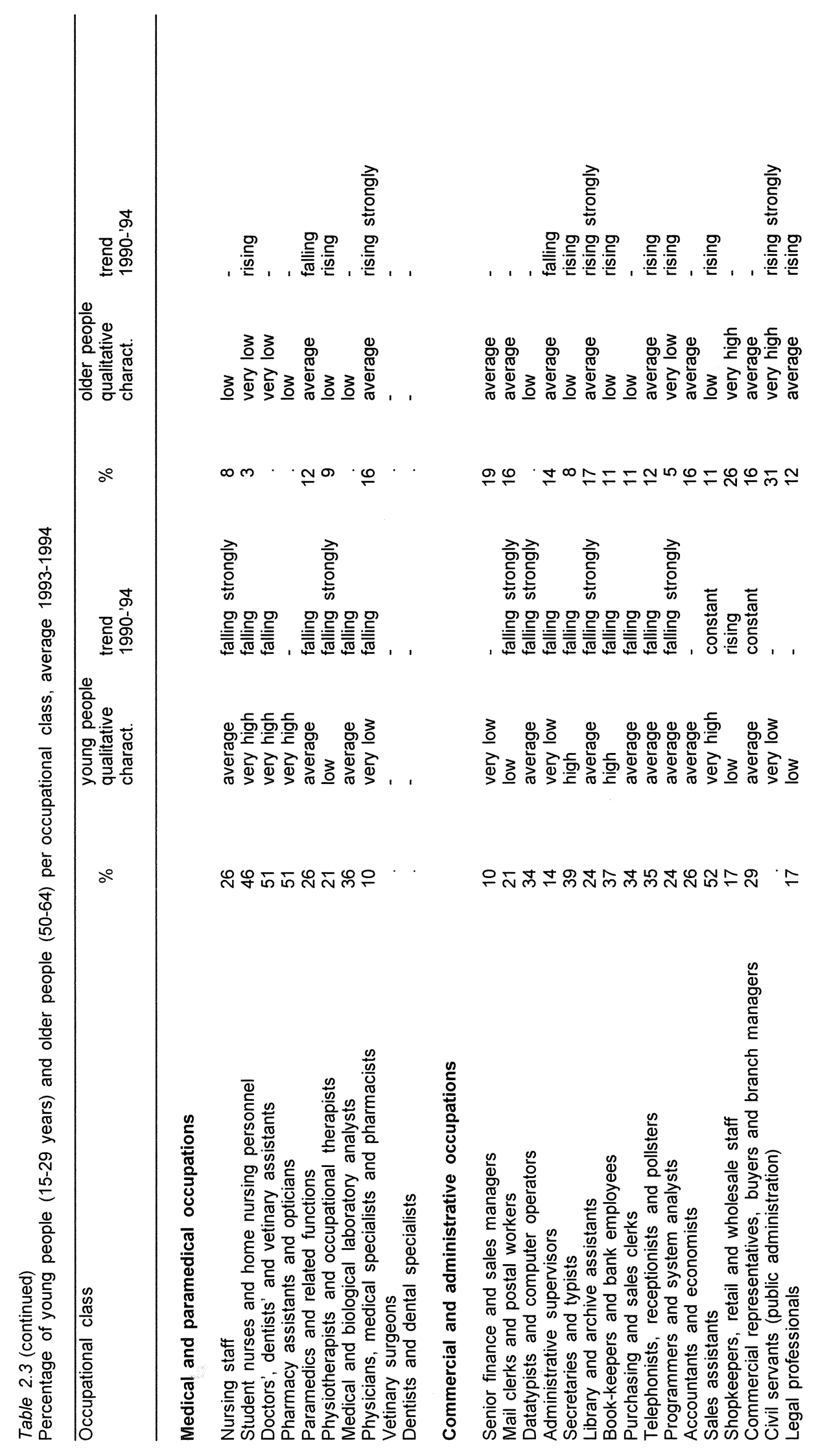




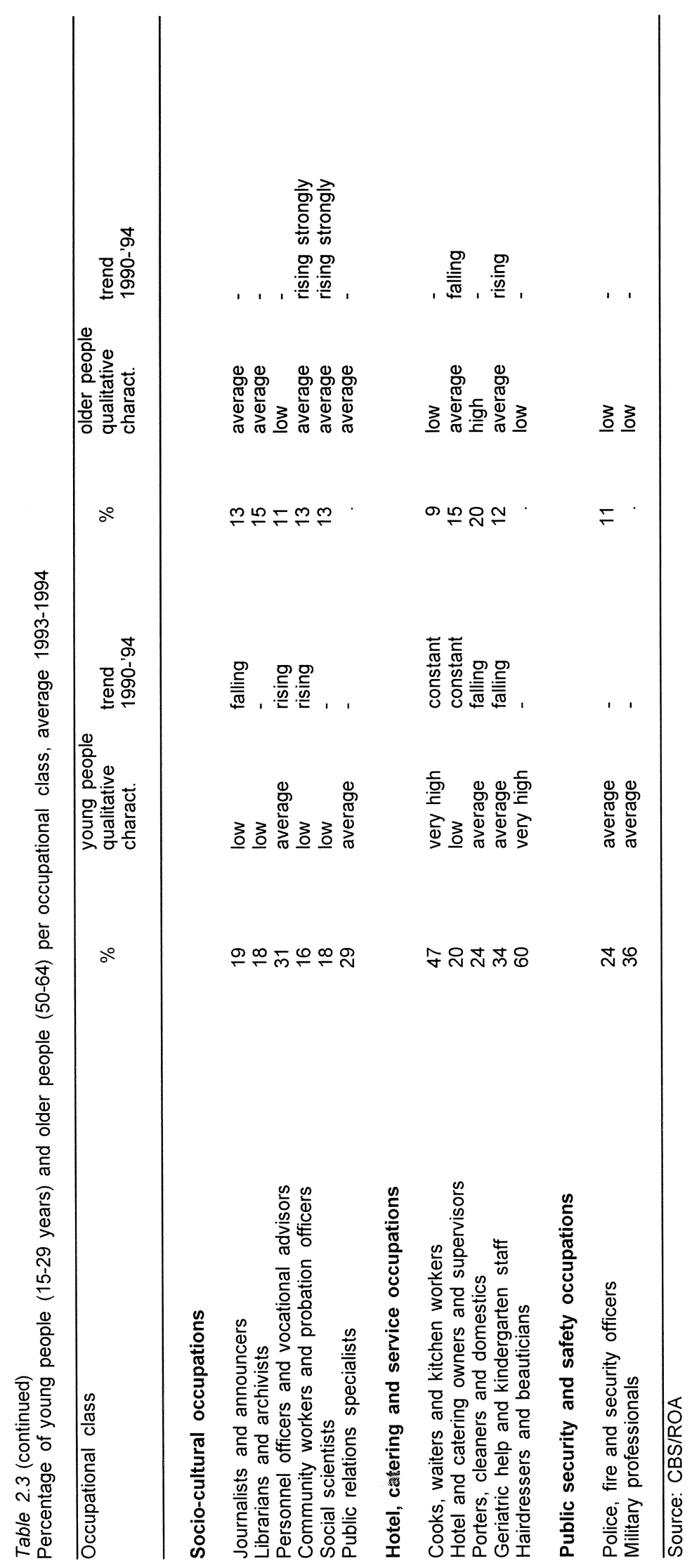


Table 2.4

Percentage of members of ethnic minorities per occupational class, average 1993-1994

Occupational class $\%$ qualitative trend

charact. 1992-'94

\section{Educational occupations}

Primary and special education teachers

Secondary and tertiary education teachers

School principals and other higher educational professions

Trainers, sports officials and sports professionals

\section{Cultural occupations}

Translators and other literary professions

Pastoral vocations

Photographers and designers

Visual and performing artists

\section{Agricultural occupations}

Agricultural workers

Farmers

Agricultural and environmental engineers

\section{Technical and industrial occupations}

Forklift drivers

Construction machine operators

Managers and supervisors in manufacturing

Technical and medical representatives

Technical draughtsmen

Technical analysts and laboratory assistants

Scientific researchers, technicians and statisticians

Food and beverage processors

Bakers and bakery personne

Textile production workers

Upholsterers, shoemakers and leatherworkers

Clothing production workers and sailmakers

Wood, paper and cardboard product workers

Carpenters and woodworkers

Printing industry production workers

Chemical process workers

Smelter workers and drilling hands

Metal-processing machine operators

Welders and engineering workers

Lathe operators and metal workers

Machinery mechanics and instrument makers

Automobile mechanics

Intermediate mechanical engineers

Higher mechanical engineers

Electrical product assembly workers and quality controllers

Electricity and gas supply workers

Electricians and telecommunication servicemen

Intermediate electrical engineers

Higher electrical engineers

Ceramic and glass industry production workers

Bricklayers and plasterers

Glaziers and concreting hands

Painters

Plumbers

Road construction workers and pipelayers

Construction supervisors

Architects and construction engineers

$\begin{array}{ll}\text { average } & - \\ \text { low } & - \\ \text { very low } & \text { rising strongly } \\ \text { low } & -\end{array}$

low

very low

average

average

rising strongly

rising strongly

average

very low

very low

$\begin{array}{ll}\text { very high } & \text { rising strongly } \\ \text { very low } & \text { falling strongly } \\ \text { very low } & \text { rising strongly } \\ \text { very low } & - \\ \text { low } & \text { falling strongly } \\ \text { low } & \text { rising strongly } \\ \text { very low } & \text { rising strongly } \\ \text { very high } & \text { falling strongly } \\ \text { average } & - \\ \text { very high } & - \\ \text { average } & - \\ \text { very high } & \text { rising strongly } \\ \text { high } & - \\ \text { average } & - \\ \text { average } & - \\ \text { high } & \text { rising strongly } \\ \text { very high } & \text { rising strongly } \\ \text { very high } & \text { falling strongly } \\ \text { very high } & - \\ \text { average } & \text { rising strongly } \\ \text { average } & - \\ \text { average } & \text { rising strongly } \\ \text { very low } & - \\ \text { low } & \text { rising strongly } \\ \text { very high } & \text { falling } \\ \text { average } & - \\ \text { average } & - \\ \text { average } & - \\ \text { very low } & - \\ \text { very high } & \text { rising strongly } \\ \text { very low } & - \\ \text { average } & \text { rising strongly } \\ \text { low } & \text { rising strongly } \\ \text { average } & \text { rising strongly } \\ \text { average } & \text { falling strongly } \\ \text { average } & - \\ \text { very low } & \text { rising strongly }\end{array}$


Table 2.4 (continued)

Percentage of members of ethnic minorities per occupational class, average 1993-1994

\begin{tabular}{llll}
\hline Occupational class & $\%$ & $\begin{array}{l}\text { qualitative } \\
\text { charact. }\end{array}$ & $\begin{array}{c}\text { trend } \\
1992-' 94\end{array}$ \\
\hline
\end{tabular}

\section{Transport occupations}

Freight handlers and packers

Fishermen and gamekeepers

Sailors, deckhands and engine-room workers

Ship's officers and marine inspectors

Drivers and conductors

Pilots and transport and freight supervisors

\section{Medical and paramedical occupations}

Nursing staff

$\begin{array}{rll}11 & \text { very high } & - \\ . & \text { very low } & - \\ . & \text { very low } & - \\ 2 & \text { very low } & - \\ 2 & \text { low } & \text { rising strongly } \\ . & \text { average } & -\end{array}$

Student nurses and home nursing personnel

Doctors', dentists' and vetinary assistants

Pharmacy assistants and opticians

Paramedics and related functions

Physiotherapists and occupational therapists

Medical and biological laboratory analysts

Physicians, medical specialists and pharmacists

Vetinary surgeons

Dentists and dental specialists

Commercial and administrative occupations

Senior finance and sales managers

Mail clerks and postal workers

Datatypists and computer operators

Administrative supervisors

Secretaries and typists

Library and archive assistants

Book-keepers and bank employees

Purchasing and sales clerks

Telephonists, receptionists and pollsters

Programmers and system analysts

Accountants and economists

Sales assistants

Shopkeepers, retail and wholesale staff

Commercial representatives, buyers and branch managers

Civil servants (public administration)

Legal professionals low
average
low
low
low
very low
average
very low
very low
average

low

average

average

low

low

average

average

average

low

very low

low

low

very low

very low

very low

very low

very low

very low

very low

average

low

low

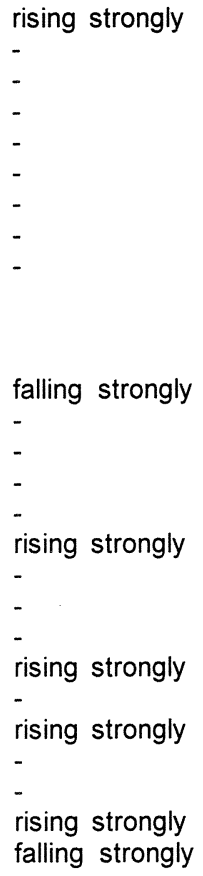$$
\text { - }
$$$$
\text { - }
$$

falling strongly

-

$-$

rising strongly

-

rising strongly

rising strongly

-

rising strongly

falling strongly

\section{Socio-cultural occupations}

Journalists and announcers

Personnel officers and vocational advisors

Community workers and probation officers

Social scientists

Public relations specialists

Hotel, catering and service occupations

Cooks, waiters and kitchen workers

Hotel and catering owners and supervisors

Porters, cleaners and domestics

Geriatric help and kindergarten staff

Hairdressers and beauticians

$\begin{array}{ll}\text { average } & \text { rising strongly } \\ \text { average } & - \\ \text { very high } & - \\ \text { average } & - \\ \text { low } & \text { falling }\end{array}$


Table 2.4 (continued)

Percentage of members of ethnic minorities per occupational class, average 1993-1994

Occupational class

$\% \quad$ qualitative

trend

charact.

1992-'94

Public security and safety occupations

Police, fire and security officers

Military professionals

average

very low

Source: CBS/ROA

- The percentage relates to the members of those ethnic minorities which fall under the 'Promotion of Balanced Employment Participation by Members of Ethnic Minorities Act' (Wet Bevordering Evenredige Arbeidsdeelname Allochtonen, WBEAA): i.e., those from Aruba, the Dutch Antilles, Ethiopia, Iraq, Iran, the former Yugoslavia, Morocco, Somalia, Surinam, Turkey and Vietnam. 


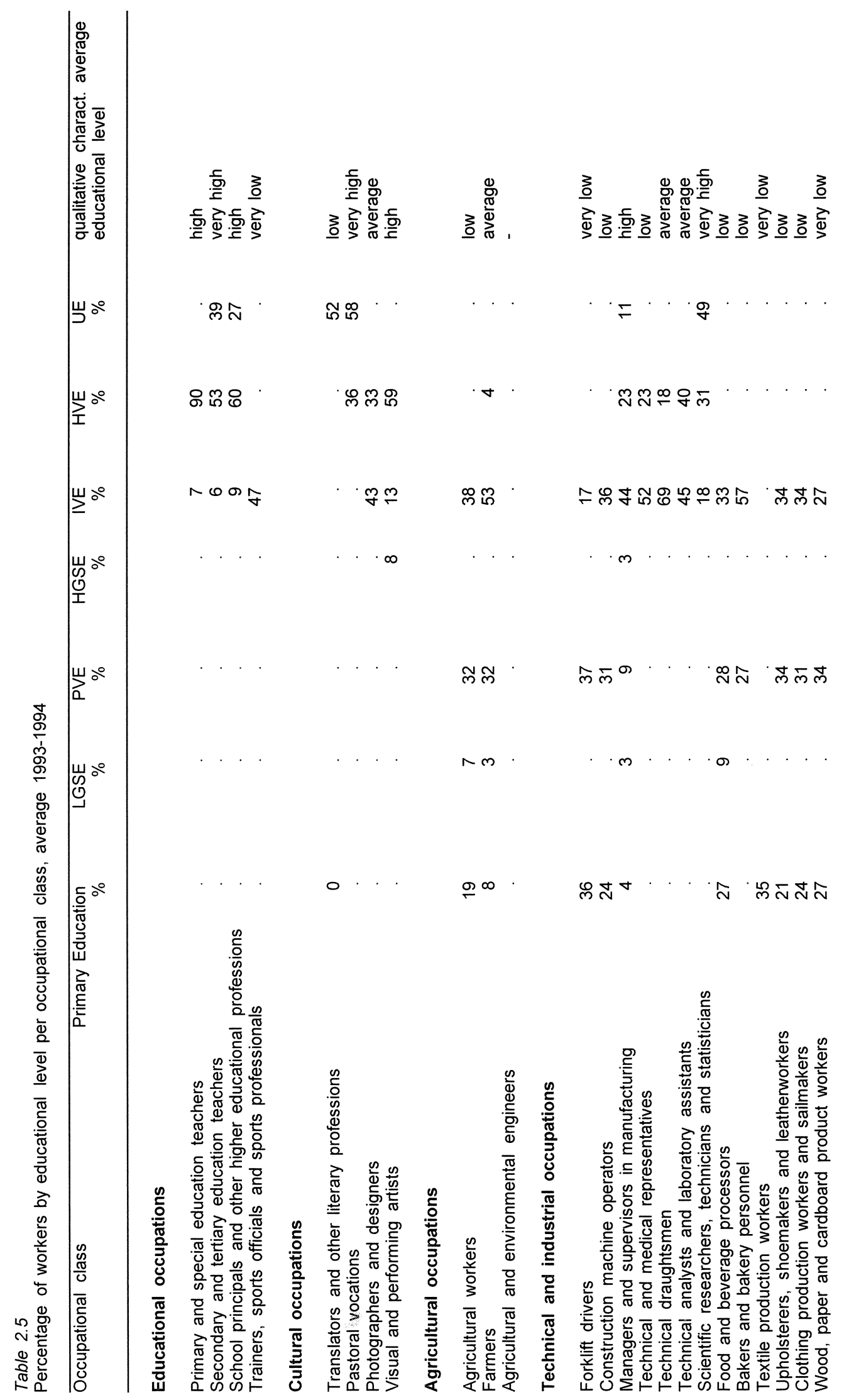




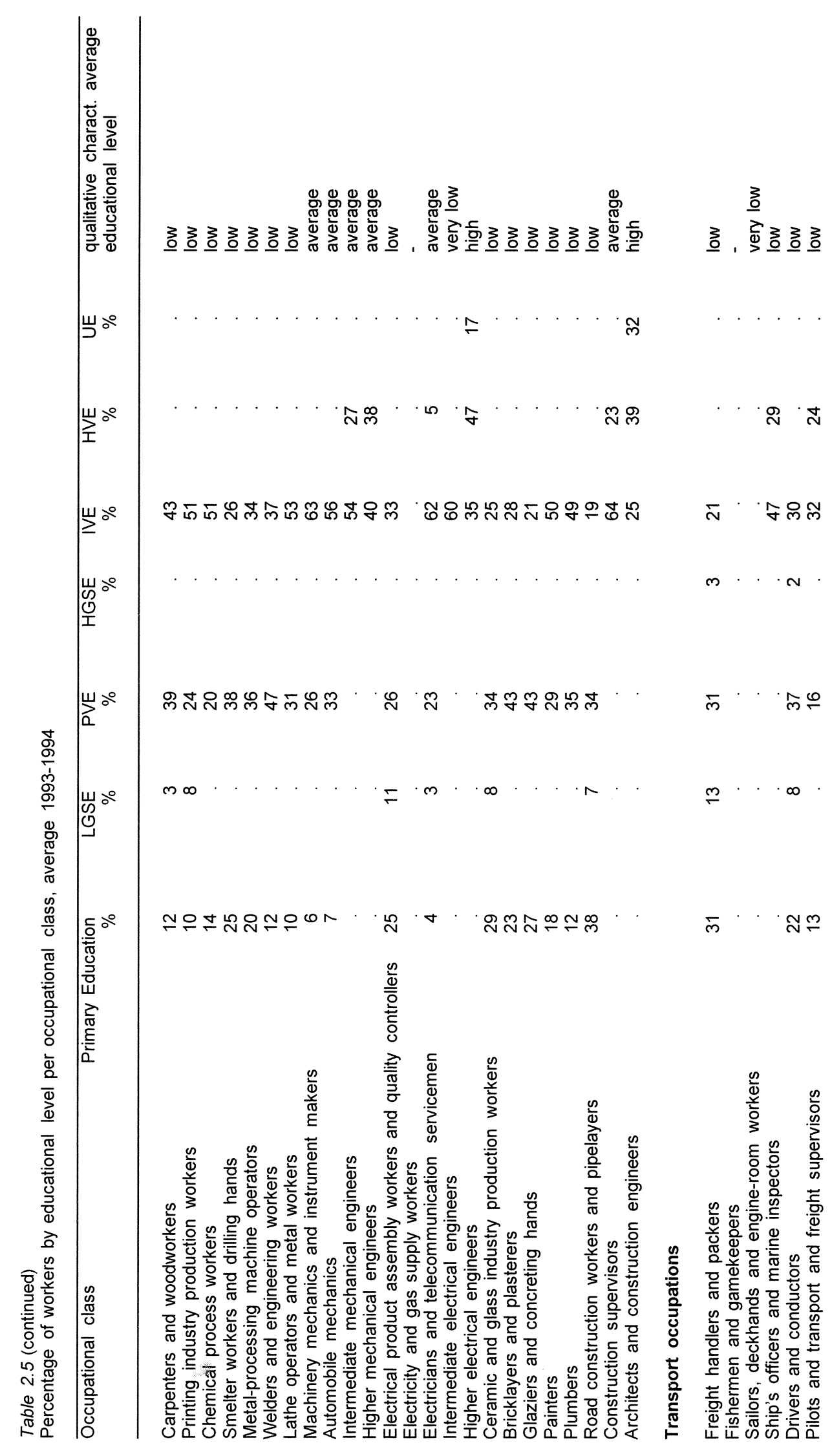




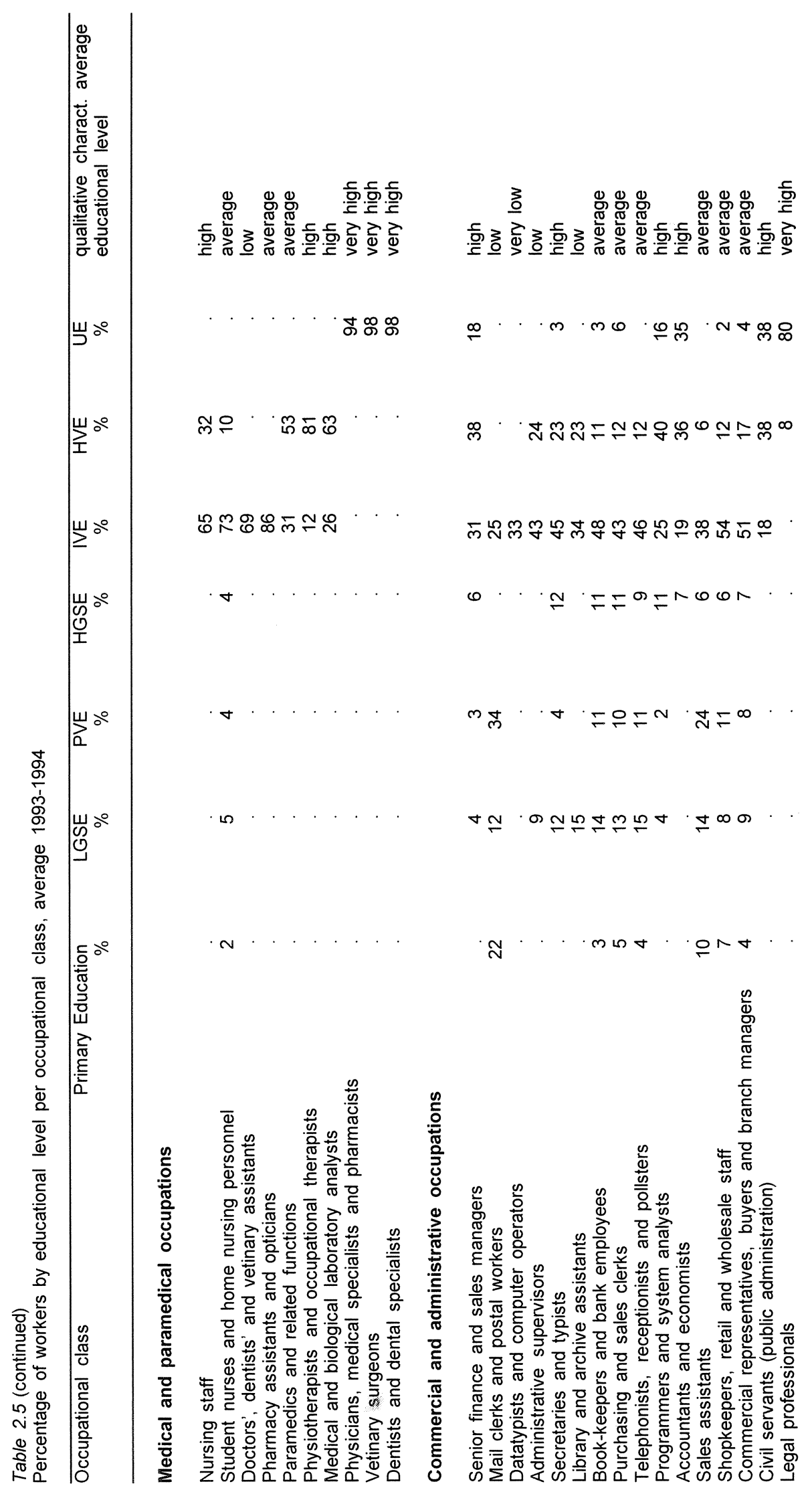




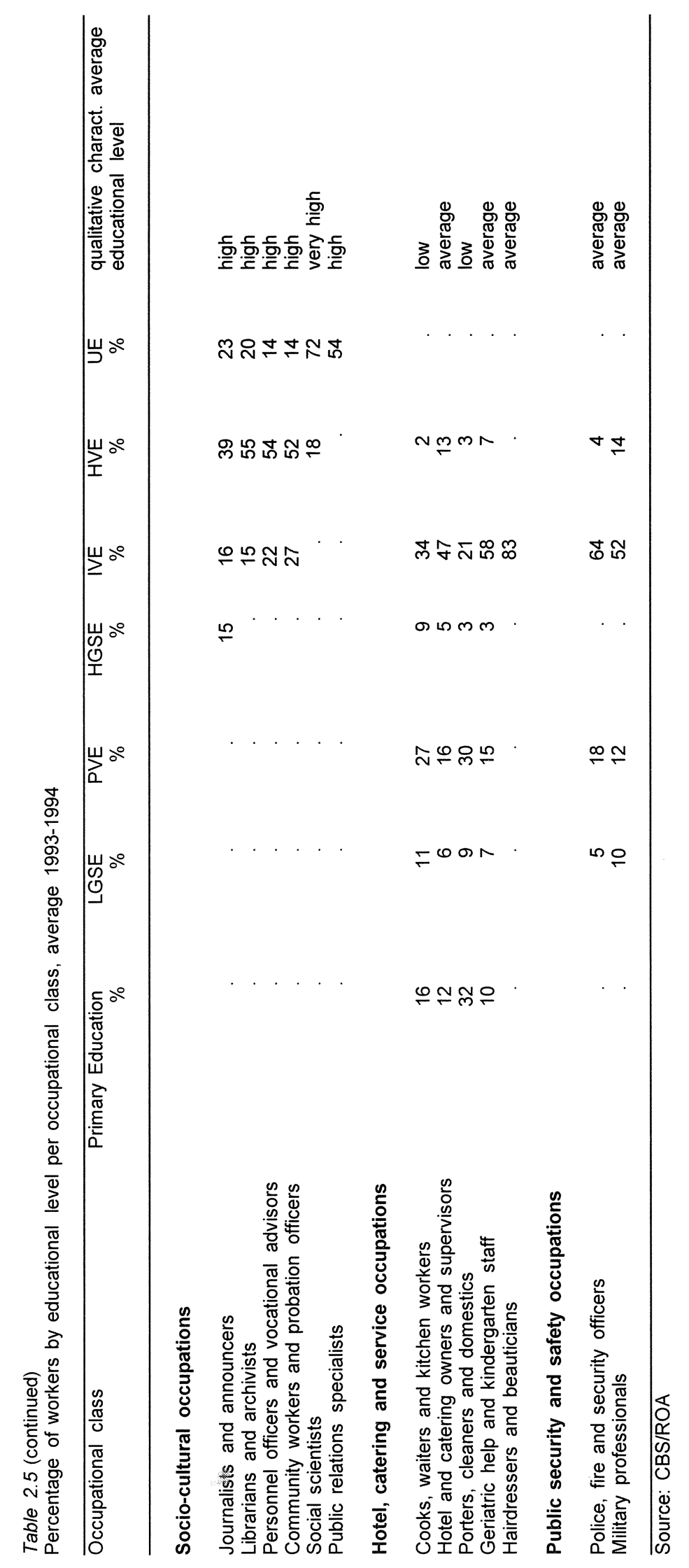


Table 2.6

Part-time work per occupational class, average 1993-1994

\begin{tabular}{llll}
\hline Occupational class & $\%$ & $\begin{array}{l}\text { qualitative } \\
\text { charact. }\end{array}$ & $\begin{array}{c}\text { trend } \\
1992-' 94\end{array}$ \\
\hline
\end{tabular}

\section{Educational occupations}

Primary and special education teachers

Secondary and tertiary education teachers

School principals and other higher educational professions

Trainers, sports officials and sports professionals

$\begin{array}{ll}\text { high } & \text { rising strongly } \\ \text { average } & - \\ \text { average } & \text { rising } \\ \text { high } & \text { rising strongly }\end{array}$

\section{Cultural occupations}

Translators and other literary professions

Pastoral vocations

Photographers and designers

Visual and performing artists

\section{Agricultural occupations}

Agricultural workers

Farmers

Agricultural and environmental engineers

\section{Technical and industrial occupations}

Forklift drivers

Construction machine operators

Managers and supervisors in manufacturing

Technical and medical representatives

Technical draughtsmen

Technical analysts and laboratory assistants

Scientific researchers, technicians and statisticians

Food and beverage processors

Bakers and bakery personnel

Textile production workers

Upholsterers, shoemakers and leatherworkers

Clothing production workers and sailmakers

Wood, paper and cardboard product workers

Carpenters and woodworkers

Printing industry production workers

Chemical process workers

Smelter workers and drilling hands

Metal-processing machine operators

Welders and engineering workers

Lathe operators and metal workers

Machinery mechanics and instrument makers

Automobile mechanics

Intermediate mechanical engineers

Higher mechanical engineers

Electrical product assembly workers and quality controllers

Electricity and gas supply workers

Electricians and telecommunication servicemen

Intermediate electrical engineers

Higher electrical engineers

Ceramic and glass industry production workers

Bricklayers and plasterers

Glaziers and concreting hands

Painters

Plumbers

Road construction workers and pipelayers

Construction supervisors

Architects and construction engineers

$\begin{array}{ll}\text { high } & - \\ \text { average } & - \\ \text { average } & \text { falling } \\ \text { average } & -\end{array}$

$\begin{array}{ll}\text { average } & \text { falling } \\ \text { low } & \text { rising strongly }\end{array}$

low

rising strongly

low

very low -

low rising strongly

very low -

$\begin{array}{ll}\text { very low } & \text { - } \\ \text { average } & \text { rising strongly }\end{array}$

low

low

low

low

average

high

low

low

low

low

very low

very low

very low

very low

very low

low

very low

very low

average

very low

low

very low

very low

low

very low

very low

very low

very low

low

very low

rising strongly

falling strongly

-

rising strongly

falling

-

-

rising

-

$-$

rising

-

rising strongly

rising strongly

-

$-$

rising strongly 
Table 2.6 (continued)

Part-time work per occupational class, average 1993-1994

Occupational class $\%$

$\% \quad$ qualitative trend

charact 1992-'94

\section{Transport occupations}

Freight handlers and packers

Fishermen and gamekeepers

Sailors, deckhands and engine-room workers

Ship's officers and marine inspectors

Drivers and conductors

Pilots and transport and freight supervisors

\section{Medical and paramedical occupations}

Nursing staff

Student nurses and home nursing personnel

Doctors', dentists' and vetinary assistants

Pharmacy assistants and opticians

Paramedics and related functions

Physiotherapists and occupational therapists

Medical and biological laboratory analysts

Physicians, medical specialists and pharmacists

Vetinary surgeons

Dentists and dental specialists

Commercial and administrative occupations

Senior finance and sales managers

Mail clerks and postal workers

Datatypists and computer operators

Administrative supervisors

Secretaries and typists

Library and archive assistants

Book-keepers and bank employees

Purchasing and sales clerks

Telephonists, receptionists and pollsters

Programmers and system analysts

Accountants and economists

Sales assistants

Shopkeepers, retail and wholesale staff

Commercial representatives, buyers and branch managers

Civil servants (public administration)

Legal professionals

19

10

$\begin{array}{rll}54 & \text { very high } & \text { rising } \\ 53 & \text { very high } & \text { rising } \\ 63 & \text { very high } & \text { rising } \\ 42 & \text { high } & \text { rising strongly } \\ 48 & \text { high } & \text { rising } \\ 47 & \text { high } & \text { falling } \\ 37 & \text { high } & \text { constant } \\ 21 & \text { average } & - \\ . & \text { average } & - \\ . & \text { low } & -\end{array}$

\section{Socio-cultural occupations}

Journalists and announcers

Librarians and archivists

Personnel officers and vocational advisors

Community workers and probation officers

Social scientists

Public relations specialists

Hotel, catering and service occupations

Cooks, waiters and kitchen workers

Hotel and catering owners and supervisors

Porters, cleaners and domestics

Geriatric help and kindergarten staff

Hairdressers and beauticians

$\begin{array}{ll}\text { low } & \text { rising strongly } \\ \text { average } & - \\ \text { high } & \text { falling } \\ \text { low } & \text { rising strongly } \\ \text { high } & \text { constant } \\ \text { high } & - \\ \text { average } & \text { rising } \\ \text { average } & \text { constant } \\ \text { high } & - \\ \text { low } & - \\ \text { low } & - \\ \text { high } & \text { rising } \\ \text { low } & \text { rising strongly } \\ \text { low } & \text { rising strongly } \\ \text { low } & \text { falling } \\ \text { average } & \text { rising strongly }\end{array}$

average rising

high -

very high rising

high rising

average -

$\begin{array}{ll}\text { high } & \text { rising } \\ \text { low } & - \\ \text { very high } & \text { constant } \\ \text { very high } & - \\ \text { high } & \text { constant }\end{array}$


Table 2.6 (continued)

Part-time work per occupational class, average 1993-1994

Occupational class

$\%$

qualitative

trend

charact.

1992-'94

Public security and safety occupations

Police, fire and security officers

Military professionals

7

low

Source: CBS/ROA 
Table 2.7

Self-employment per occupational class, average 1993-1994

\begin{tabular}{llll}
\hline Occupational class & $\%$ & $\begin{array}{l}\text { qualitative } \\
\text { charact. }\end{array}$ & $\begin{array}{l}\text { trend } \\
1992-94\end{array}$ \\
\hline
\end{tabular}

\section{Educational occupations}

Primary and special education teachers

very low

Secondary and tertiary education teachers 3

School principals and other higher educational professions

Trainers, sports officials and sports professionals

\section{Cultural occupations}

Translators and other literary professions

Pastoral vocations

Photographers and designers

Visual and performing artists

$\begin{array}{rll}51 & \text { very high } & \text { rising } \\ 42 & \text { very high } & - \\ 60 & \text { very high } & \text { rising } \\ & \text { very high } & \text { rising }\end{array}$

\section{Agricultural occupations}

Agricultural workers

Farmers

Agricultural and environmental engineers

$\begin{array}{ll}\text { high falling strongly } \\ \text { very high } & \text { constant }\end{array}$

\section{Technical and industrial occupations}

Forklift drivers

Construction machine operators

Managers and supervisors in manufacturing

Technical and medical representatives

Technical draughtsmen

Technical analysts and laboratory assistants

Scientific researchers, technicians and statisticians

Food and beverage processors

Bakers and bakery personnel

Textile production workers

Upholsterers, shoemakers and leatherworkers

Clothing production workers and sailmakers

Wood, paper and cardboard product workers

Carpenters and woodworkers

Printing industry production workers

Chemical process workers

Smelter workers and drilling hands

Metal-processing machine operators

Welders and engineering workers

Lathe operators and metal workers

Machinery mechanics and instrument makers

Automobile mechanics

Intermediate mechanical engineers

Higher mechanical engineers

Electrical product assembly workers and quality controllers

Electricity and gas supply workers

Electricians and telecommunication servicemen

Intermediate electrical engineers

Higher electrical engineers

Ceramic and glass industry production workers

Bricklayers and plasterers

Glaziers and concreting hands

Painters

Plumbers

Road construction workers and pipelayers

Construction supervisors

Architects and construction engineers

very low

high

very low

very low

very low

very low

very low

high

high

high

average

low

very low

very low

very low

very low

very low

very low

average

very low

very low

very low

very low

very low

very low

very low

average

low

average

low

very low

very low

high rising strongly$$
-
$$$$
\text { rising strongly }
$$$$
\text { rising }
$$$$
\text { falling }
$$$$
\text { - }
$$$$
\text { - }
$$$$
-
$$

rising strongly

falling strongly

-

$-$$$
-
$$$$
-
$$$$
-
$$$$
-
$$

rising strongly

-

rising strongly falling strongly 
Table 2.7 (continued)

Self-employment per occupational class, average 1993-1994

\begin{tabular}{llll}
\hline Occupational class & $\%$ & qualitative & trend \\
charact. & & 1992-'94
\end{tabular}

\section{Transport occupations}

Freight handlers and packers

Fishermen and gamekeepers

Sailors, deckhands and engine-room workers

Ship's officers and marine inspectors

Drivers and conductors

Pilots and transport and freight supervisors

charact.

Medical and paramedical occupations

Nursing staff

Student nurses and home nursing personnel

Doctors', dentists' and vetinary assistants

Pharmacy assistants and opticians

Paramedics and related functions

Physiotherapists and occupational therapists

Medical and biological laboratory analysts

Physicians, medical specialists and pharmacists

very low

low

very low

very low

very low

very low

very high

very high

very low

very high

very high

very high

Dentists and dental specialists

Commercial and administrative occupations

Senior finance and sales managers

Mail clerks and postal workers

Datatypists and computer operators

Administrative supervisors

Secretaries and typists

Library and archive assistants

Book-keepers and bank employees

Purchasing and sales clerks

Telephonists, receptionists and pollsters

Programmers and system analysts

Accountants and economists

Sales assistants

Shopkeepers, retail and wholesale staff

Commercial representatives, buyers and branch managers 10

Civil servants (public administration)

Legal professionals

very low very low

very low

very low

very low

very low

very low

very low

very low

high

low

very high

average

low

high

rising

rising

constant

Socio-cultural occupations

Journalists and announcers

Librarians and archivists

Personnel officers and vocational advisors

Community workers and probation officers

Social scientists

Public relations specialists

Hotel, catering and service occupations

Cooks, waiters and kitchen workers

Hotel and catering owners and supervisors

Porters, cleaners and domestics

Geriatric help and kindergarten staff

Hairdressers and beauticians

high

very low

very low

average

-

very low

very high

very low

very low

very high falling strongly

rising strongly constant

constant

falling strongly

rising 
Table 2.7 (continued)

Self-employment per occupational class, average 1993-1994

Occupational class

$\% \quad \begin{aligned} & \text { qualitative } \\ & \text { charact. }\end{aligned}$

trend

1992-'94

Public security and safety occupations

Police, fire and security officers

Military professionals

very low

very low

Source: ROA/CBS

- Including people working in the business or practice of their spouse or parents, and freelancers etc. 
Table 2.8

Most important economic sectors per occupational class, average 1993-1994

Occupational class $\%$ trend

1990-'94

Primary and special education teachers

Civil service, police, defense and education

97

constant

Secondary and tertiary education teachers

Civil service, police, defense and education

$87 \quad$ falling

School principals and other higher educational professions

Civil service, police, defense and education

Non-commercial services

Other commercial services

6 falling strongly

Trainers, sports officials and sports professionals

Non-commercial services

Translators and other literary professions

Other commercial services

$50 \quad$ falling

Pastoral vocations

Non-commercial services

95

constant

Photographers and designers

Other commercial services

Commerce

Non-commercial services

Other industry

rising strongly

falling strongly

Visual and performing artists

Non-commercial services

constant

\section{Agricultural workers}

Agriculture and fisheries

Metal and electrical industries

Civil service, police, defense and education

constant

11 rising strongly

8 falling

\section{Farmers}

Agriculture and fisheries

93

constant

Forklift drivers

Commerce

Transport, storage and communication

Other industry

Metal and electrical industries

Food and beverage industry

$\begin{array}{ll}19 & \text { constant } \\ 16 & - \\ 15 & - \\ 14 & \text { falling } \\ 13 & \text { falling }\end{array}$


Table 2.8 (continued)

Most important economic sectors per occupational class, average 1993-1994

Occupational class $\%$ trend

\section{Construction machine operators}

Construction

Transport, storage and communication

Agriculture and fisheries

Managers and supervisors in manufacturing

Other commercial services

Metal and electrical industries

Construction

Other industry

Commerce

Non-commercial services

Transport, storage and communication

Technical and medical representatives

Commerce

Technical draughtsmen

Other commercial services

Metal and electrical industries

Civil service, police, defense and education

Construction

Technical analysts and laboratory assistants

Chemicals

Civil service, police, defense and education

Other commercial services

Non-commercial services

Food and beverage industry

Scientific researchers, technicians and statisticians

Civil service, police, defense and education

Other commercial services

Non-commercial services

Metal and electrical industries

Chemicals

Food and beverage processors

Food and beverage industry

Commerce

Bakers and bakery personnel

Food and beverage industry

91

Textile production workers

Other industry falling

12

25

23

32

constant

falling

falling

falling strongly

constant

falling strongly

$-$

rising strongly

falling

falling strongly

rising

$-$

-

74

constant 
Table 2.8 (continued)

Most important economic sectors per occupational class, average 1993-1994

\begin{tabular}{lll}
\hline Occupational class & $\%$ & trend \\
& $1990-94$ \\
\hline
\end{tabular}

Upholsterers, shoemakers and leatherworkers

Other industry

Commerce

44

34

Clothing production workers and sailmakers

Other industry

Commerce

$54 \quad$ falling

18 rising strongly

Wood, paper and cardboard product workers

Other industry

Carpenters and woodworkers

Construction

Other industry

Metal and electrical industries

$56 \quad$ constant

19

Printing industry production workers

Other industry

Metal and electrical industries

71

12

constant

rising

Chemical process workers

Chemicals

Energy

61

11 rising strongly

Smelter workers and drilling hands

Metal and electrical industries

constant

Metal-processing machine operators

Metal and electrical industries

Commerce

78

10 rising strongly

Welders and engineering workers

Metal and electrical industries

Construction

$77 \quad$ constant

Lathe operators and metal workers

Metal and electrical industries

Commerce

Other commercial services

Construction constant

rising

rising 
Table 2.8 (continued)

Most important economic sectors per occupational class, average 1993-1994

\begin{tabular}{lll}
\hline Occupational class & $\%$ & trend \\
& $1990-94$
\end{tabular}

Machinery mechanics and instrument makers

Metal and electrical industries

Commerce

Other industry

Chemicals

Transport, storage and communication

Food and beverage industry

$\begin{aligned} 26 & \text { falling } \\ 19 & \text { rising } \\ 9 & - \\ 9 & - \\ 9 & \text { rising } \\ 8 & \text { falling strongly }\end{aligned}$

Automobile mechanics

Other commercial services

Commerce

Transport, storage and communication

60
18
7

Higher mechanical engineers

Metal and electrical industries

Other commercial services

Electrical product assembly workers and quality controllers

Metal and electrical industries

Other industry

Chemicals

falling

rising strongly

Electricians and telecommunication servicemen

Construction

Metal and electrical industries

Commerce

Transport, storage and communication

Other commercial services

Non-commercial services

$23 \quad-$

Higher electrical engineers

Metal and electrical industries

Other commercial services

Ceramic and glass industry production workers

Chemicals

Metal and electrical industries

Other industry

Other commercial services

Commerce

-

rising

Bricklayers and plasterers

Construction

Glaziers and concreting hands

Construction 
Table 2.8 (continued)

Most important economic sectors per occupational class, average 1993-1994

\begin{tabular}{lll}
\hline Occupational class & $\%$ & trend \\
& $1990-' 94$ \\
\hline
\end{tabular}

\section{Painters}

Construction

88

constant

\section{Plumbers}

Construction

Metal and electrical industries

Energy

$\begin{aligned} 77 & \text { constant } \\ 9 & \text { falling } \\ 6 & -\end{aligned}$

Road construction workers and pipelayers

Construction

Metal and electrical industries

Other commercial services

Civil service, police, defense and education

14 rising strongly

13 falling strongly

Construction supervisors

Construction

Civil service, police, defense and education

Other commercial services

rising

Architects and construction engineers

Other commercial services

Civil service, police, defense and education

Construction

Freight handlers and packers

Commerce

Metal and electrical industries

Food and beverage industry

Transport, storage and communication

Other commercial services

Other industry

Chemicals

constant

falling

falling

falling

Sailors, deckhands and engine-room workers

Transport, storage and communication

Ship's officers and marine inspectors

Transport, storage and communication

constant

Drivers and conductors

Transport, storage and communication

Commerce

Civil service, police, defense and education

$\begin{array}{ll}65 & \text { constant } \\ 11 & \text { falling }\end{array}$

Pilots and transport and freight supervisors

Transport, storage and communication

66

rising 
Table 2.8 (continued)

Most important economic sectors per occupational class, average 1993-1994

\begin{tabular}{lll}
\hline Occupational class & $\%$ & trend \\
$1990-' 94$
\end{tabular}

Nursing staff

Non-commercial services

Student nurses and home nursing personnel

Non-commercial services

constant

Doctors', dentists' and vetinary assistants

Non-commercial services

constant

Pharmacy assistants and opticians

Commerce

Non-commercial services

Paramedics and related functions

Non-commercial services

Civil service, police, defense and education

Physiotherapists and occupational therapists

Non-commercial services

Medical and biological laboratory analysts

Non-commercial services

82

constant

Physicians, medical specialists and pharmacists

Non-commercial services

Civil service, police, defense and education

81

9

constant

rising strongly

Mail clerks and postal workers

Transport, storage and communication

Civil service, police, defense and education

Datatypists and computer operators

Other commercial services

\section{Administrative supervisors}

Civil service, police, defense and education

Other commercial services

Non-commercial services

Secretaries and typists

Non-commercial services

Other commercial services

Civil service, police, defense and education

Commerce

Metal and electrical industries

Financial services

constant

rising

falling

falling

falling 
Table 2.8 (continued)

Most important economic sectors per occupational class, average 1993-1994

\begin{tabular}{lll}
\hline Occupational class & $\%$ & trend \\
& 1990 -' 94 \\
\hline
\end{tabular}

\section{Library and archive assistants}

Civil service, police, defense and education

Non-commercial services

$43 \quad$ rising

34

Book-keepers and bank employees

Financial services

Commerce

Other commercial services

Civil service, police, defense and education

Transport, storage and communication

Non-commercial services

Purchasing and sales clerks

Civil service, police, defense and education Commerce

Transport, storage and communication

Financial services

Other commercial services

Metal and electrical industries

Non-commercial services

Telephonists, receptionists and pollsters

Civil service, police, defense and education

Transport, storage and communication

Non-commercial services

Other commercial services

Commerce

rising

constant

falling

falling

falling

falling

falling

Programmers and system analysts

Other commercial services

Civil service, police, defense and education

Metal and electrical industries

Commerce

Financial services

Transport, storage and communication

Non-commercial services

rising

falling

constant

Accountants and economists

Other commercial services

Civil service, police, defense and education

Financial services

Commerce

Non-commercial services

constant

falling

falling

rising strongly

Sales assistants

Commerce

Food and beverage industry

$79 \quad$ constant

Shopkeepers, retail and wholesale staff

Commerce

$80 \quad$ falling 
Table 2.8 (continued)

Most important economic sectors per occupational class, average 1993-1994

Occupational class $\%$ trend

1990-'94

Commercial representatives, buyers and branch managers

Commerce

Financial services

Other commercial services

Other industry

Construction

Metal and electrical industries

Civil servants (public administration)

Civil service, police, defense and education

\section{Legal professionals}

Other commercial services

Civil service, police, defense and education

Journalists and announcers

Other industry

Non-commercial services

Other commercial services

Civil service, police, defense and education

Librarians and archivists

Non-commercial services

Civil service, police, defense and education

Personnel officers and vocational advisors

Other commercial services

Civil service, police, defense and education

Non-commercial services

Community workers and probation officers

Non-commercial services

Civil service, police, defense and education

Social scientists

Non-commercial services

Civil service, police, defense and education

69 rising

25 falling

\section{Public relations specialists}

Civil service, police, defense and education Non-commercial services

Cooks, waiters and kitchen workers

Other commercial services

Non-commercial services

Civil service, police, defense and education

$\begin{aligned} 59 & \text { constant } \\ 21 & \text { constant } \\ 5 & -\end{aligned}$


Table 2.8 (continued)

Most important economic sectors per occupational class, average 1993-1994

\begin{tabular}{lll}
\hline Occupational class & $\%$ & trend \\
& & $1990-' 94$
\end{tabular}

Hotel and catering owners and supervisors

Other commercial services

Non-commercial services

66

22

Porters, cleaners and domestics

Other commercial services

Non-commercial services

Civil service, police, defense and education

Transport, storage and communication

$\begin{aligned} 38 & - \\ 29 & \text { constant } \\ 13 & \text { constant } \\ 6 & \text { rising }\end{aligned}$

Geriatric help and kindergarten staff

Non-commercial services

$91 \quad$ constant

Hairdressers and beauticians

Other commercial services

$97 \quad$ constant

Police, fire and security officers

Civil service, police, defense and education

Other commercial services

$70 \quad$ constant

17 rising strongly

Military professionals

Civil service, police, defense and education

100

constant

Source: CBS/ROA 
Table 2.9

Opportunities to switch to various economic sub-sectors, per occupational class, average 1993-1994

Occupational class Gini-Hirschman qualitative

\section{Educational occupations}

Primary and special education teachers

Secondary and tertiary education teachers

School principals and other higher educational professions

Trainers, sports officials and sports professionals

0.20

0.22

0.57

0.48

\section{Cultural occupations}

Translators and other literary professions

Pastoral vocations

Photographers and designers

Visual and performing artists

0.72

0.35

0.86

0.38

0.52

0.10

0.90

Agricultural workers

Farmers

Agricultural and environmental engineers

Technical and industrial occupations

Forklift drivers

0.97

Construction machine operators

0.86

Managers and supervisors in manufacturing

Technical and medical representatives

Technical draughtsmen

Technical analysts and laboratory assistants

Scientific researchers, technicians and statisticians

Food and beverage processors

Bakers and bakery personnel

Textile production workers

Upholsterers, shoemakers and leatherworkers

Clothing production workers and sailmakers

Wood, paper and cardboard product workers

Carpenters and woodworkers

Printing industry production workers

Chemical process workers

Smelter workers and drilling hands

Metal-processing machine operators

Welders and engineering workers

Lathe operators and metal workers

Machinery mechanics and instrument makers

Automobile mechanics

Intermediate mechanical engineers

Higher mechanical engineers

Electrical product assembly workers and quality controllers

Electricity and gas supply workers

Electricians and telecommunication servicemen

Intermediate electrical engineers

Higher electrical engineers

Ceramic and glass industry production workers

Bricklayers and plasterers

Glaziers and concreting hands

Painters

Plumbers

Road construction workers and pipelayers average

very low

low

average

low

average

low

high

low

very low

high

very high

high

very high

average

average

very high

very high

average

very low

average

average

average

average

average

average

average

average

high

average

high

very high

average

very high

high

average

average

high

high

high

high

very low

low

low

average

average 
Table 2.9 (continued)

Opportunities to switch to various economic sub-sectors per occupational class, average 1993-1994

Occupational class $\quad$ Gini-Hirschman qualitative

dispersion index charact.

Construction supervisors

Architects and construction engineers

Transport occupations

Freight handlers and packers

Fishermen and gamekeepers

Sailors, deckhands and engine-room workers

0.67

Pilots and transport and freight supervisors

\section{Medical and paramedical occupations}

Nursing staff

Student nurses and home nursing personne

Doctors', dentists' and vetinary assistants

Pharmacy assistants and opticians

Paramedics and related functions

Physiotherapists and occupational therapists

Medical and biological laboratory analysts

Physicians, medical specialists and pharmacists

Vetinary surgeons

Dentists and dental specialists

very high

low

average

average

average

very high

low

low

very low

average

low

very low

low

low

very low

low

\section{Commercial and administrative occupations}

0.40

0.45

0.42

0.19

0.24
Senior finance and sales managers

Mail clerks and postal workers

Datatypists and computer operators

Administrative supervisors

Secretaries and typists

0.91

0.92

0.83

Library and archive assistants

Book-keepers and bank employees

Purchasing and sales clerks

Telephonists, receptionists and pollsters

Programmers and system analysts

Accountants and economists

Sales assistants

Shopkeepers, retail and wholesale staff

commercial representatives, buyers and branch managers

Legal professionals

very high

low

very high

very high

very high

average

very high

very high

very high

high

average

average

average

very high

very low

average

\section{Socio-cultural occupations}

Journalists and announcers

Librarians and archivists

Personnel officers and vocational advisors

Community workers and probation officers

Social scientists

Public relations specialists

$\begin{array}{ll}0.83 & \text { average } \\ 0.86 & \text { high } \\ 0.82 & \text { average } \\ 0.72 & \text { average } \\ 0.78 & \text { average } \\ 0.91 & \text { very high }\end{array}$


Table 2.9 (continued)

Opportunities to switch to various economic sub-sectors, per occupational class, average 1993-1994

\begin{tabular}{lll}
\hline Occupational class & $\begin{array}{l}\text { Gini-Hirschman } \\
\text { dispersion index }\end{array}$ & $\begin{array}{l}\text { qualitative } \\
\text { charact. }\end{array}$
\end{tabular}

Hotel, catering and service occupations

Cooks, waiters and kitchen workers

0.55

Hotel and catering owners and supervisors

Porters, cleaners and domestics

Geriatric help and kindergarten staff

0.37

Hairdressers and beauticians

high

low

Public security and safety occupations

Police, fire and security officers

Military professionals

$0.48 \quad$ low

0.00 very low

Source: ROA 
Table 2.10

Most important types of education per occupational class, average 1993-1994

\begin{tabular}{lll}
\hline Occupational class & $\%$ & trend
\end{tabular}

1992-'94

Primary and special education teachers

HVE Teacher training

$88 \quad$ constant

Secondary and tertiary education teachers

HVE Teacher training

UE Arts

UE Social sciences

UE Mathematics and natural sciences

6 falling strongly

School principals and other higher educational professions

HVE Teacher training

UE Social sciences

$43 \quad$ rising

12 constant

Trainers, sports officials and sports professionals

Translators and other literary professions

UE Arts

Pastoral vocations

UE Theology

Photographers and designers

HVE Fine Arts

IVE Printing technology

23 rising

13 falling

Visual and performing artists

HVE Fine Arts

HVE Teacher training

Higher General Secondary Education

$44 \quad$ rising

11
8

Agricultural workers

IVE Agriculture and the natural environment Primary Education

PVE Agriculture

PVE Community care, hotel and catering

Lower General Secondary Education

27 rising

19 constant

13 falling

\section{Farmers}

IVE Agriculture and the natural environment

PVE Agriculture

Primary Education

$\begin{array}{ll}41 & \text { rising } \\ 23 & \text { falling strongly }\end{array}$

8 falling strongly

Agricultural and environmental engineers 
Table 2.10 (continued)

Most important types of education per occupational class, average 1993-1994

Occupational class $\quad \%$ trend

Forklift drivers

Primary Education

36

falling strongly

Construction machine operators

Primary Education

IVE Mechanical engineering

PVE Mechanical trades

$\begin{array}{ll}24 & \text { falling } \\ 16 & - \\ 10 & \text { rising }\end{array}$

Managers and supervisors in manufacturing

IVE Construction technology

IVE Retail

$\begin{array}{ll}7 & \text { rising } \\ 5 & \text { rising strongly }\end{array}$

Technical and medical representatives

Technical draughtsmen

IVE Construction technology

IVE Mechanical engineering

IVE Electrical technology

HVE Construction and civil engineering

IVE Civil engineering

19 rising strongly

17

14

rising strongly

rising

Technical analysts and laboratory assistants

HVE Technical laboratory

IVE Technical Laboratory

$30 \quad$ rising strongly

22 rising strongly

Scientific researchers, technicians and statisticians

UE Mathematics and natural sciences

Food and beverage processors

Primary Education

IVE Food technology

Lower General Secondary Education

Bakers and bakery personnel

IVE Food technology

rising strongly

PVE Food trades

Textile production workers

Primary Education

Upholsterers, shoemakers and leatherworkers Primary Education

IVE Textile and leather technology 
Table 2.10 (continued)

Most important types of education per occupational class, average 1993-1994

Occupational class $\quad \%$ trend

1992-'94

\section{Clothing production workers and sailmakers}

Primary Education

IVE Textile and leather technology

PVE Community care, hotel and catering

24

21

16

Wood, paper and cardboard product workers

Primary Education

\section{Carpenters and woodworkers}

IVE Construction technology

PVE Construction trades

Primary Education

$\begin{array}{ll}33 & \text { rising } \\ 31 & \text { falling } \\ 12 & \text { constant }\end{array}$

Printing industry production workers

IVE Printing technology

Primary Education

Lower General Secondary Education

PVE Printing trades

$\begin{aligned} 34 & - \\ 11 & \text { rising } \\ 8 & - \\ 7 & \text { falling strongly }\end{aligned}$

Chemical process workers

IVE Process technologies

Primary Education

rising

Smelter workers and drilling hands

Primary Education

falling strongly

Metal-processing machine operators

Primary Education

PVE Mechanical trades

20

17

falling strongly

Welders and engineering workers

PVE Mechanical trades

IVE Metalworking

Primary Education

IVE Mechanical engineering

$\begin{aligned} 36 & \text { rising } \\ 20 & \text { rising } \\ 12 & \text { falling strongly } \\ 6 & \text { rising strongly }\end{aligned}$

Lathe operators and metal workers

PVE Mechanical trades

IVE Metalworking

Primary Education

IVE Mechanical engineering

IVE Electrical technology

IVE Automobile technology

$\begin{aligned} 20 & \text { rising } \\ 18 & - \\ 10 & \text { falling } \\ 9 & \text { rising strongly } \\ 7 & - \\ 5 & -\end{aligned}$


Table 2.10 (continued)

Most important types of education per occupational class, average 1993-1994

Occupational class $\quad \% \quad$ trend

1992-'94

Machinery mechanics and instrument makers

IVE Mechanical engineering

IVE Electrical technology

PVE Mechanical trades

IVE Metalworking

IVE Automobile technology

Primary Education

$\begin{array}{ll}17 & - \\ 14 & \text { rising strongly } \\ 3 & - \\ 9 & - \\ 6 & - \\ 6 & -\end{array}$

Automobile mechanics

IVE Automobile technology

PVE Automobile trades

Primary Education

$\begin{aligned} 45 & \text { falling } \\ 23 & \text { rising strongly } \\ 7 & \text { falling strongly }\end{aligned}$

Intermediate mechanical engineers

Higher mechanical engineers

HVE Mechanical engineering

IVE Mechanical engineering

21

falling strongly

Electrical product assembly workers and quality controllers

Primary Education

Lower General Secondary Education

Electricity and gas supply workers

Electricians and telecommunication servicemen

IVE Electrical technology

PVE Electrical trades

Intermediate electrical engineers

Higher electrical engineers

HVE Electronic and information technology

IVE Electrical technology

UE Electrical engineering and information technology

34

Ceramic and glass industry production workers

Primary Education

PVE Mechanical trades

Lower General Secondary Education

PVE Construction trades falling strongly

falling

rising strongly

rising 
Table 2.10 (continued)

Most important types of education per occupational class, average 1993-1994

\begin{tabular}{lll}
\hline Occupational class & trend
\end{tabular}

1992-'94

\section{Bricklayers and plasterers}

PVE Construction trades

Primary Education

IVE Construction technology

32

falling strongly

19 constant

\section{Glaziers and concreting hands}

Primary Education

PVE Construction trades

falling strongly rising strongly

\section{Painters}

IVE Construction technology

PVE Construction trades

Primary Education

Plumbers

IVE Construction technology

PVE Mechanical trades

Primary Education

PVE Utilities installation

Road construction workers and pipelayers

Primary Education

PVE Construction trades

PVE Mechanical trades

Lower General Secondary Education

rising strongly falling strongly

rising

rising strongly

falling strongly

Construction supervisors

IVE Construction technology

HVE Construction and civil engineering

IVE Civil engineering

rising strongly

falling

Architects and construction engineers

HVE Construction and civil engineering

UE Construction and civil engineering

IVE Construction technology

rising

falling

Freight handlers and packers

Primary Education

Lower General Secondary Education

PVE Community care, hotel and catering

IVE Retail

PVE Construction trades

Fishermen and gamekeepers

Sailors, deckhands and engine-room workers 
Table 2.10 (continued)

Most important types of education per occupational class, average 1993-1994

Occupational class $\%$ trend

1992-'94

Ship's officers and marine inspectors

IVE Transport and harbour

HVE Transport and harbour

44

Drivers and conductors

Primary Education

PVE Transport and harbour

Lower General Secondary Education

IVE Transport and harbour

PVE Mechanical trades

Pilots and transport and freight supervisors

HVE Transport and harbour

Primary Education

19

13

rising strongly

Nursing staff

IVE Nursing and paramedical services

HVE Nursing and paramedical services

60

Student nurses and home nursing personnel

IVE Nursing and paramedical services

IVE Community care

Lower General Secondary Education

IVE Social and cultural

$22 \quad$ rising

8 rising

$6-$

$6-$

$-$

rising

falling

falling

-

$-$

Doctors', dentists' and vetinary assistants

IVE Nursing and paramedical services

Pharmacy assistants and opticians

IVE Medical laboratory

80

constant

\section{Paramedics and related functions}

HVE Nursing and paramedical services

IVE Nursing and paramedical services

43

14

constant

falling strongly

Physiotherapists and occupational therapists

HVE Nursing and paramedical services

rising strongly

Medical and biological laboratory analysts

HVE Medical laboratory

HVE Technical laboratory

IVE Medical laboratory

$46 \quad$ rising

$14 \quad$ falling

10 rising strongly

Physicians, medical specialists and pharmacists

UE Veterinary and medical sciences and dentistry UE Pharmacy $\begin{aligned} 83 & - \\ 7 & \text { falling strongly }\end{aligned}$ 
Table 2.10 (continued)

Most important types of education per occupational class, average 1993-1994

\begin{tabular}{lll}
\hline Occupational class & $\%$ & trend \\
& $1992-94$
\end{tabular}

\section{Vetinary surgeons}

UE Veterinary and medical sciences and dentistry

Dentists and dental specialists

UE Veterinary and medical sciences and dentistry

Senior finance and sales managers

HVE Social and cultural

IVE Administration

Higher General Secondary Education

Mail clerks and postal workers

Primary Education

Lower General Secondary Education

IVE Retail

Datatypists and computer operators

\section{Administrative supervisors}

Lower General Secondary Education

Secretaries and typists

IVE Secretarial

Lower General Secondary Education

Higher General Secondary Education

IVE Retail

\section{Library and archive assistants}

Lower General Secondary Education

IVE Social and cultural

HVE Social and cultural

Book-keepers and bank employees

IVE Administration

Lower General Secondary Education

Higher General Secondary Education

IVE Retail

Purchasing and sales clerks

Lower General Secondary Education

Higher General Secondary Education

IVE Retail

IVE Secretarial
98

constant

rising

falling strongly

falling strongly

rising

falling

falling strongly

constant

falling

falling 
Table 2.10 (continued)

Most important types of education per occupational class, average 1993-1994

\begin{tabular}{lll}
\hline Occupational class & $\%$ & trend \\
$1992-' 94$
\end{tabular}

1992-'94

Telephonists, receptionists and pollsters

Lower General Secondary Education

Higher General Secondary Education

IVE Secretarial

IVE Retail

IVE Tourism and recreation

PVE Community care, hotel and catering

falling

falling strongly

Programmers and system analysts

HVE Commercial information science

Higher General Secondary Education

HVE Electronic and information technology

rising

Accountants and economists

UE Economics, econometrics and business administration

HVE Accounting

IVE Administration

Higher General Secondary Education

$\begin{array}{ll}11 & \text { rising } \\ 10 & \end{array}$

\section{Sales assistants}

IVE Retail

Lower General Secondary Education

PVE Community care, hotel and catering

Primary Education

Higher General Secondary Education

Shopkeepers, retail and wholesale staff

IVE Retail

Lower General Secondary Education

Primary Education

Higher General Secondary Education

rising

rising strongly

Commercial representatives, buyers and branch managers

IVE Retail

Lower General Secondary Education

Higher General Secondary Education

IVE Commerce

rising

constant

falling

rising

falling

constant

falling strongly

Civil servants (public administration)

HVE Legal and fiscal

UE Social sciences

UE Law

14 rising strongly

Legal professionals

UE Law

constant

Journalists and announcers

Higher General Secondary Education

HVE Social and cultural

UE Arts

constant 
Table 2.10 (continued)

Most important types of education per occupational class, average 1993-1994

\begin{tabular}{lll}
\hline Occupational class & $\%$ & trend
\end{tabular}

1992-'94

Librarians and archivists

HVE Social and cultural

\section{Personnel officers and vocational advisors}

HVE Social and cultural

IVE Social and cultural

36

8

Community workers and probation officers

HVE Social and cultural

UE Social sciences

IVE Social and cultural

IVE Nursing and paramedical services

11

7

falling strongly

rising strongly

rising strongly

Social scientists

UE Social sciences

HVE Social and cultura

$51 \quad$ falling

13 falling strongly

Public relations specialists

Cooks, waiters and kitchen workers

IVE Community care

PVE Community care, hotel and catering

Primary Education

Lower General Secondary Education

Higher General Secondary Education

IVE Hotel, catering and hairdressing

Hotel and catering owners and supervisors

IVE Hotel, catering and hairdressing

Primary Education

IVE Community care

PVE Community care, hotel and catering

IVE Retail

Lower General Secondary Education

Porters, cleaners and domestics

Primary Education

PVE Community care, hotel and catering

Lower General Secondary Education

IVE Community care

\section{Geriatric help and kindergarten staff}

IVE Community care

PVE Community care, hotel and catering

Primary Education

Lower General Secondary Education

IVE Social and cultural

IVE Nursing and paramedical services constant

falling strongly

rising

rising strongly

rising strongly

rising

rising strongly

falling strongly

falling strongly

falling

rising

$-$

constant

falling strongly

falling strongly

rising strongly rising strongly 
Table 2.10 (continued)

Most important types of education per occupational class, average 1993-1994

Occupational class

$\% \quad$ trend

1992-'94

Hairdressers and beauticians

IVE Community care

IVE Hotel, catering and hairdressing

50

rising strongly

Police, fire and security officers

IVE Police, fire and defense

PVE Security

Lower General Secondary Education

49 falling

9 rising strongly

Military professionals

IVE Police, fire and defense

HVE Police, fire and defense

Lower General Secondary Education

40 rising

11 -

Source: CBS/ROA 
Table 2.11

Possibilities of substituting workers with other educational backgrounds per occupational class, average 1993-1994

\begin{tabular}{lll}
\hline Occupational class & $\begin{array}{l}\text { Gini-Hirschman } \\
\text { dispersion index }\end{array}$ & $\begin{array}{l}\text { qualitative } \\
\text { charact. }\end{array}$
\end{tabular}

\section{Educational occupations}

Primary and special education teachers

Secondary and tertiary education teachers

School principals and other higher educational professions

Trainers, sports officials and sports professionals

very low

high

high

high

\section{Cultural occupations}

Translators and other literary professions

Pastoral vocations

Photographers and designers

Visual and performing artists

low

high

\section{Agricultural occupations}

Agricultural workers

Farmers

Agricultural and environmental engineers

Technical and industrial occupations

Forklift drivers

Construction machine operators

Managers and supervisors in manufacturing

Technical and medical representatives

Technical draughtsmen

Technical analysts and laboratory assistants

Scientific researchers, technicians and statisticians

Food and beverage processors

Bakers and bakery personnel

Textile production workers

Upholsterers, shoemakers and leatherworkers

Clothing production workers and sailmakers

Wood, paper and cardboard product workers

Carpenters and woodworkers

Printing industry production workers

Chemical process workers

Smelter workers and drilling hands

Metal-processing machine operators

Welders and engineering workers

Lathe operators and metal workers

Machinery mechanics and instrument makers

Automobile mechanics

Intermediate mechanical engineers

Higher mechanical engineers

Electrical product assembly workers and quality controllers

Electricity and gas supply workers

Electricians and telecommunication servicemen 0.72

Intermediate electrical engineers

Ceramic and glass industry production workers

Bricklayers and plasterers

Glaziers and concreting hands

Painters

Plumbers

Road construction workers and pipelayers

high

average

low

average

average

average

average

low

average

high

average

high

average

average

high

low

high

average

high

low

low

low

low

average

average

average

low

average

average 
Table 2.11 (continued)

Possibilities of substituting workers with other educational backgrounds per occupational class, average 1993-1994

Occupational class Gini-Hirschman qualitative

dispersion index charact.

Construction supervisors

0.83

average

Architects and construction engineers

\section{Transport occupations}

Freight handlers and packers

Fishermen and gamekeepers

Sailors, deckhands and engine-room workers

Ship's officers and marine inspectors

Pilots and transport and freight supervisors

\section{Medical and paramedical occupations}

Nursing staff

Student nurses and home nursing personne

Doctors', dentists' and vetinary assistants

Pharmacy assistants and opticians

Paramedics and related functions

Physiotherapists and occupational therapists

Medical and biological laboratory analysts

Physicians, medical specialists and pharmacists

Vetinary surgeons

Dentists and dental specialists

low

Commercial and administrative occupations

Senior finance and sales managers

Mail clerks and postal workers

Datatypists and computer operators

Administrative supervisors

Library and archive assistants

Book-keepers and bank employees

Purchasing and sales clerks

Telephonists, receptionists and pollsters

Programmers and system analysts

Accountants and economists

Sales assistants

Shopkeepers, retail and wholesale staff

Commercial representatives, buyers and branch managers

Civil servants (public administration)

\section{Socio-cultural occupations}

Journalists and announcers

Personnel officers and vocational advisors

Community workers and probation officers

Social scientists

high

high

high

high

high

high

high

average

high

high

very low

low

average 
Table 2.11 (continued)

Possibilities of substituting workers with other educational backgrounds per occupational class, average 1993-1994

\begin{tabular}{lll}
\hline Occupational class & $\begin{array}{l}\text { Gini-Hirschman } \\
\text { dispersion index }\end{array}$ & $\begin{array}{l}\text { qualitatve } \\
\text { charact. }\end{array}$
\end{tabular}

Hotel, catering and service occupations

$\begin{array}{lll}\text { Cooks, waiters and kitchen workers } & 0.91 & \text { high } \\ \text { Hotel and catering owners and supervisors } & 0.93 & \text { high } \\ \text { Porters, cleaners and domestics } & 0.86 & \text { average } \\ \text { Geriatric help and kindergarten staff } & 0.87 & \text { average }\end{array}$

Geriatric help and kindergarten staff

Hairdressers and beauticians

0.66

low

Public security and safety occupations

Police, fire and security officers $\quad 0.75$ low

Military professionals $\quad 0.86 \quad$ average

Source: ROA 
Table 2.12

Sensitivity to the state of the business cycle per occupational class

\begin{tabular}{lll}
\hline Occupational class & sensitivity & qualitative \\
& to business cycle & charact.
\end{tabular}

\section{Educational occupations}

Primary and special education teachers

Secondary and tertiary education teachers

School principals and other higher educational professions

\section{Cultural occupations}

Translators and other literary professions

Pastoral vocations

Photographers and designers

Visual and performing artists

Agricultural occupations

Agricultural workers

Farmers

Technical and industrial occupations

Forklift drivers

$\begin{array}{ll}1.26 & \text { high } \\ 0.70 & \text { average } \\ 1.22 & \text { high } \\ 0.88 & \text { average } \\ 0.84 & \text { average } \\ 1.32 & \text { high } \\ 0.75 & \text { average } \\ 0.65 & \text { average } \\ 0.62 & \text { average } \\ 0.96 & \text { average } \\ 0.61 & \text { average } \\ 0.92 & \text { average } \\ 0.93 & \text { average } \\ 1.63 & \text { high } \\ 2.54 & \text { very high } \\ 1.00 & \text { average } \\ 0.46 & \text { low } \\ 1.39 & \text { high } \\ 1.48 & \text { high } \\ 0.84 & \text { average } \\ 0.84 & \text { average } \\ 0.46 & \text { low } \\ 0.90 & \text { average } \\ 1.70 & \text { high } \\ 0.84 & \text { average } \\ 1.74 & \text { high } \\ 1.92 & \text { very high } \\ 2.36 & \text { very high } \\ 2.79 & \text { very high } \\ 0.91 & \text { average } \\ 1.70 & \text { high } \\ 1.68 & \text { high } \\ 1.73 & \text { high } \\ 4.54 & \text { very high } \\ 3.20 & \text { very high } \\ 1.25 & \text { high } \\ 1.39 & \text { high } \\ & \\ 0.9\end{array}$

Construction machine operators

Managers and supervisors in manufacturing

Technical and medical representatives

Technical draughtsmen

Technical analysts and laboratory assistants

Scientific researchers, technicians and statisticians

Food and beverage processors

Bakers and bakery personnel

Textile production workers

Upholsterers, shoemakers and leatherworkers

Clothing production workers and sailmakers

Wood, paper and cardboard product workers

Carpenters and woodworkers

Printing industry production workers

Chemical process workers

Smelter workers and drilling hands

Metal-processing machine operators

Welders and engineering workers

Lathe operators and metal workers

Machinery mechanics and instrument makers

Automobile mechanics

Intermediate mechanical engineers

Higher mechanical engineers

Electrical product assembly workers and quality controllers

Electricity and gas supply workers

Electricians and telecommunication servicemen

Intermediate electrical engineers

Higher electrical engineers

Ceramic and glass industry production workers

Bricklayers and plasterers

Glaziers and concreting hands

Painters

Plumbers

Road construction workers and pipelayers

Construction supervisors

Architects and construction engineers

high 
Table 2.12 (continued)

Sensitivity to the state of the business cycle per occupational class

\begin{tabular}{lll}
\hline Occupational class & $\begin{array}{l}\text { sensitivity } \\
\text { to business cycle }\end{array}$ & $\begin{array}{l}\text { qualitative } \\
\text { charact. }\end{array}$ \\
\hline
\end{tabular}

\section{Transport occupations}

Freight handlers and packers

Fishermen and gamekeepers

average

Sailors, deckhands and engine-room workers

0.33

0.72

Ship's officers and marine inspectors

0.24

0.85

Drivers and conductors

0.32

low

average

very low

average

Pilots and transport and freight supervisors

low

\section{Medical and paramedical occupations}

Nursing staff

Student nurses and home nursing personnel

Doctors', dentists' and vetinary assistants

Pharmacy assistants and opticians

0.14

0.59

Paramedics and related functions

Physiotherapists and occupational therapists

0.14

Medical and biological laboratory analysts

0.14

Physicians, medical specialists and pharmacists

0.33

Vetinary surgeons

Dentists and dental specialists

low

very low

very low

low

average

low

\section{Commercial and administrative occupations}

Senior finance and sales managers

Mail clerks and postal workers

0.94

0.67

0.68

0.60
0.77

Datatypists and computer operators

Secretaries and typists

Library and archive assistants

Book-keepers and bank employees

Purchasing and sales clerks

Telephonists, receptionists and pollsters

Programmers and system analysts

Accountants and economists

0.66

0.64

1.03

0.68

0.85

0.60

Sales assistants

Shopkeepers, retail and wholesale staff

Commercial representatives, buyers and branch managers

0.53

0.85

0.76

Civil servants (public administration)

Legal professionals

\section{Socio-cultural occupations}

Journalists and announcers

Librarians and archivists

Personnel officers and vocational advisors

Community workers and probation officers

Social scientists

Public relations specialists
low
low
low
low
low
low

Hotel, catering and service occupations

Cooks, waiters and kitchen workers

Hotel and catering owners and supervisors

0.32

0.38

0.82

Porters, cleaners and domestics

Geriatric help and kindergarten staff

Hairdressers and beauticians

0.42

0.42

low

low

average

low

low 
Table 2.12 (continued)

Sensitivity to the state of the business cycle per occupational class

Occupational class

sensitivity

qualitative

charact.

Public security and safety occupations

Police, fire and security officers

0.16

Military professionals

0.00

very low

very low

Source: ROA 
Table 2.13

Expected expansion demand per occupational class, $1995-2000$

\begin{tabular}{lllll}
\hline Occupational class & number & $\begin{array}{c}\text { total } \\
\%\end{array}$ & $\begin{array}{l}\text { average } \\
\text { annual } \%\end{array}$ & $\begin{array}{l}\text { qualitative } \\
\text { charact. }\end{array}$
\end{tabular}

\section{Educational occupations}

Primary and special education teachers

$-3,200$

$\begin{array}{lr}\text { Secondary and tertiary education teachers } & 11,100 \\ \text { School principals and other higher educational professions } & 1,600\end{array}$

Trainers, sports officials and sports professionals

500

$\begin{array}{rrl}-3 & -0.7 & \text { low } \\ 7 & 1.3 & \text { average } \\ 3 & 0.6 & \text { average } \\ 4 & 0.7 & \text { average }\end{array}$

\section{Cultural occupations}

Translators and other literary professions

Pastoral vocations

Photographers and designers

Visual and performing artists

high

average

average

high

\section{Agricultural occupations}

Agricultural workers

Farmers

Agricultural and environmental engineers

Technical and industrial occupations

Forklift drivers

Construction machine operators

Managers and supervisors in manufacturing

Technical and medical representatives

Technical draughtsmen

1,200

Technical analysts and laboratory assistants

Scientific researchers, technicians and statisticians

3,700

10,000

Food and beverage processors

$-2,500$

Bakers and bakery personnel

Textile production workers

$-1,100$

$-2,100$

Upholsterers, shoemakers and leatherworkers

$-2,100$

$-1,900$
-300

$-6,700$

Wood, paper and cardboard product workers

$-6,700$
100

Carpenters and woodworkers

Printing industry production workers

Chemical process workers

Smelter workers and drilling hands

Metal-processing machine operators

Welders and engineering workers

Lathe operators and metal workers

Machinery mechanics and instrument makers

$-1,800$

Automobile mechanics

Intermediate mechanical engineers

Higher mechanical engineers

Electrical product assembly workers and quality controllers 500

Electricity and gas supply workers

Electricians and telecommunication servicemen

Intermediate electrical engineers

2,700

Higher electrical engineers

$-2,300$

Ceramic and glass industry production workers

$-2,800$

Bricklayers and plasterers

$-2,800$

$-2,500$

Painters

$-3,100$

Plumbers

$-3,1000$

$-400$

Construction supervisors

Architects and construction engineers

$\begin{array}{rrl}5 & 1.0 & \text { average } \\ 2 & 0.4 & \text { average } \\ 15 & 2.9 & \text { high } \\ 5 & 1.0 & \text { average } \\ 12 & 2.4 & \text { high } \\ 12 & 2.3 & \text { high } \\ 18 & 3.3 & \text { very high } \\ -6 & -1.2 & \text { low } \\ -5 & -1.0 & \text { low } \\ -12 & -2.6 & \text { very low } \\ -12 & -2.4 & \text { very low } \\ -11 & -2.4 & \text { very low } \\ -3 & -0.6 & \text { low } \\ -5 & -1.1 & \text { low } \\ 0 & 0.0 & \text { average } \\ 1 & 0.3 & \text { average } \\ -5 & -1.1 & \text { low } \\ -5 & -1.0 & \text { low } \\ -4 & -0.7 & \text { low } \\ -3 & -0.7 & \text { low } \\ -3 & -0.6 & \text { low } \\ -4 & -0.8 & \text { low } \\ -9 & -1.9 & \text { low } \\ -7 & -1.5 & \text { low } \\ 2 & 0.3 & \text { average } \\ 4 & 0.8 & \text { average } \\ 0 & 0.1 & \text { average } \\ -8 & -1.6 & \text { low } \\ 19 & 3.5 & \text { very high } \\ -7 & -1.3 & \text { low } \\ -6 & -1.3 & \text { low } \\ -9 & -1.8 & \text { low } \\ -8 & -1.6 & \text { low } \\ -8 & -1.6 & \text { low } \\ -7 & -1.4 & \text { low } \\ -2 & -0.3 & \text { average } \\ 5 & 0.9 & \text { average }\end{array}$


Table 2.13 (continued)

Expected expansion demand per occupational class, 1995-2000

number

Transport occupations

Freight handlers and packers

2,100

$-100$

Fishermen and gamekeepers

$-100$

200

Drivers and conductors

Pilots and transport and freight supervisors

600

Medical and paramedical occupations

Nursing staff

16,600

13,600
2,300

Student nurses and home nursing personnel

Doctors', dentists' and vetinary assistants

1,000

2,600

6,600

Physiotherapists and occupational therapists

Medical and biological laboratory analysts

2,500

5,000

300

Vetinary surgeons

Dentists and dental specialists
Sailors, deckhands and engine-room workers

0.3

$-1.1$

$-0.3$

0.3

0.3

0.6

average

low

average

average

average

average

high

high

high

average

high

very high

high

high

high

high

Commercial and administrative occupations

Senior finance and sales managers

Mail clerks and postal workers

18,100

$-1,000$

Datatypists and computer operators

$-1,500$

800

Administrative supervisors

Secretaries and typists

$-2,900$

$-900$

$-6,700$

Book-keepers and bank employees

23,000

1,400
66,700

Telephonists, receptionists and pollsters

Programmers and system analysts

15,700

Accountants and economists

42,300

Sales assistants

42,300
15,700

Commercial represent, buyers and branch managers 13,700

Civil servants (public administration)

Legal professionals

very high

low

very low average average low average low average very high very high high high high very low average

Socio-cultural occupations

Journalists and announcers

Librarians and archivists

Personnel officers and vocational advisors

Community workers and probation officers

Social scientists

Public relations specialists

$\begin{array}{rrrl}7,200 & 21 & 4.0 & \text { very high } \\ 2,700 & 16 & 3.0 & \text { high } \\ 2,700 & 8 & 1.5 & \text { average } \\ 4,200 & 6 & 1.2 & \text { average } \\ 600 & 3 & 0.6 & \text { average } \\ 1,100 & 8 & 1.5 & \text { average }\end{array}$

Hotel, catering and service occupations

Cooks, waiters and kitchen workers

Hotel and catering owners and supervisors

Porters, cleaners and domestics

Geriatric help and kindergarten staff

1,100

1,200

$-17,000$

7,400

Hairdressers and beauticians

$-3,800$

$\begin{array}{rr}1 & 0.2 \\ 2 & 0.4 \\ -11 & -2.3 \\ 6 & 1.2 \\ -11 & -2.3\end{array}$

average

average

low

average

low 
Table 2.13 (continued)

Expected expansion demand per occupational class, 1995-2000

Occupational class

qualitative

$\%$ annual \% charact.

Public security and safety occupations

Police, fire and security officers

Military professionals

3,600

$-8,800$

6
-28

1.1
-6.4

average

Source: ROA 
Table 2.14

Expected replacement demand per occupational class, 1995-2000

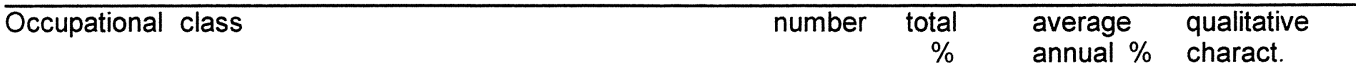

Educational occupations

Primary and special education teachers

$24,100 \quad 25$

37,600

8,900

School principals and other higher educational professions

1,900

23
17
15

\section{5}

4.3

Trainers, sports officials and sports professionals

high

average

low

\section{Cultural occupations}

Translators and other literary professions

Pastoral vocations

1,400

2,300

22

6,800

29

Photographers and designers

5,300

15

3.4

Visual and performing artists

12

Agricultural workers

Farmers

Agricultural and environmental engineers

$\begin{array}{rr}12,300 & 11 \\ 22,100 & 17\end{array}$

$600 \quad 13$

Technical and industrial occupations

Forklift drivers

Construction machine operators

Managers and supervisors in manufacturing

Technical and medical representatives

Technical draughtsmen

Technical analysts and laboratory assistants

Scientific researchers, technicians and statisticians

Food and beverage processors

Bakers and bakery personnel

Textile production workers

Upholsterers, shoemakers and leatherworkers

Clothing production workers and sailmakers

Wood, paper and cardboard product workers

Carpenters and woodworkers

Printing industry production workers

Chemical process workers

Smelter workers and drilling hands

Metal-processing machine operators

Welders and engineering workers

Lathe operators and metal workers

Machinery mechanics and instrument makers

Automobile mechanics

Intermediate mechanical engineers

Higher mechanical engineers

Electrical product assembly workers and quality controllers

Electricity and gas supply workers

Electricians and telecommunication servicemen

Intermediate electrical engineers

Higher electrical engineers

Ceramic and glass industry production workers

Bricklayers and plasterers

Glaziers and concreting hands

Painters

Plumbers

Road construction workers and pipelayers

Construction supervisors

Architects and construction engineers
$5,300 \quad 22$

$6,800 \quad 20$

$76,100 \quad 23$

$2,300 \quad 10$

$6,700 \quad 21$

$7,400 \quad 24$

$12,000 \quad 21$

$9,700 \quad 24$

$3,300 \quad 15$

$2,000 \quad 22$

$3,000 \quad 16$

$3,800 \quad 23$

$2,000 \quad 19$

$23,800 \quad 19$

$8,700 \quad 20$

$4,400 \quad 17$

$1,800 \quad 16$

$5,400 \quad 17$

$8,600 \quad 15$

$14,000 \quad 24$

$19,300 \quad 30$

9,700

3,200

1,900

4,800

400

20,300

1,800

3,000

6,500

12,000

4,400

9,500

7,100

7,100

5,500

4,300
2.2

3.2

2.4

very low

low

low

\section{1}

3.7

4.2 
Table 2.14 (continued)

Expected replacement demand per occupational class, 1995-2000

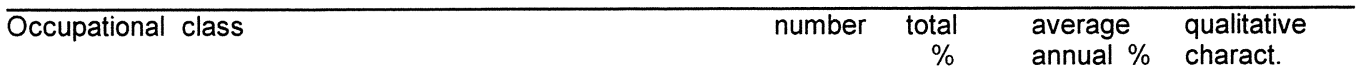

Transport occupations

Freight handlers and packers

Fishermen and gamekeepers

Sailors, deckhands and engine-room workers

Ship's officers and marine inspectors

Drivers and conductors

Pilots and transport and freight supervisors

18,500

300

600

1,500

45,900

3,700

Medical and paramedical occupations

Nursing staff

Student nurses and home nursing personnel

29,600

38,900

Doctors', dentists' and vetinary assistants

Pharmacy assistants and opticians

Paramedics and related functions

Physiotherapists and occupational therapists

Medical and biological laboratory analysts

Physicians, medical specialists and pharmacists

Vetinary surgeons

Dentists and dental specialists

16
10
11
15
25
19

$\begin{array}{ll}2.9 & \text { low } \\ 2.0 & \text { very low } \\ 2.1 & \text { very low } \\ 2.7 & \text { low } \\ 4.5 & \text { high } \\ 3.6 & \text { average }\end{array}$

Commercial and administrative occupations

Senior finance and sales managers

Mail clerks and postal workers

Datatypists and computer operators

Administrative supervisors

Library and archive assistants

Book-keepers and bank employees

63,200

Purchasing and sales clerks

49,900

Telephonists, receptionists and pollsters $\quad 17,200$

Programmers and system analysts $\quad 30,800$

Accountants and economists $\quad 11,800$

Sales assistants $\quad 48,000$

Shopkeepers, retail and wholesale staff 32,300

Commercial representatives, buyers and branch managers 31,100

Civil servants (public administration)

9,000

Legal professionals

8,100

27
31
26
18
17
22
25
25
18
23

4.8

high

very high

high

average

low

average

high

high

average

average

Socio-cultural occupations

Journalists and announcers

Librarians and archivists

8,200

3,100

4,900

Personnel officers and vocational advisors

17,900

Community workers and probation officers

4,600

2,700

high

high

very low

average

high

high

average

low

average

average

average

average

average

high

very high

high

Public relations specialists

Hotel and catering owners and supervisors

26,100

Geriatric help and kindergarten staff

26,100
4,900

high

average

low

high

average

average

Hairdressers and beauticians

21
27
21
21
14

average

high

average

average

low 
Table 2.14 (continued)

Expected replacement demand per occupational class, 1995-2000

Occupational class

number

total

average

annual \% charact.

Public security and safety occupations

Police, fire and security officers

23

3,800

12

4.2

average

Military professionals

2.3

very low

Source: ROA 


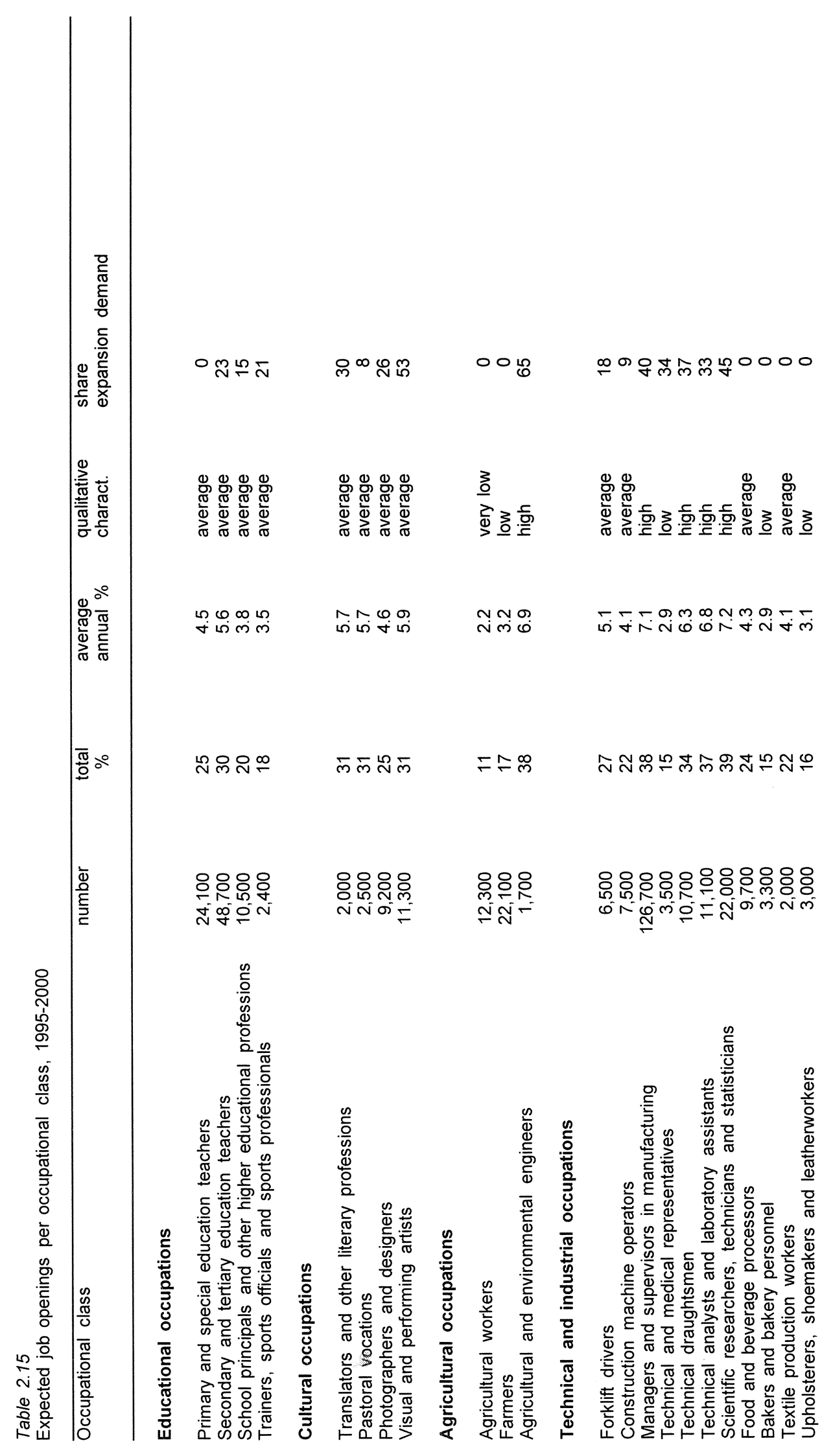




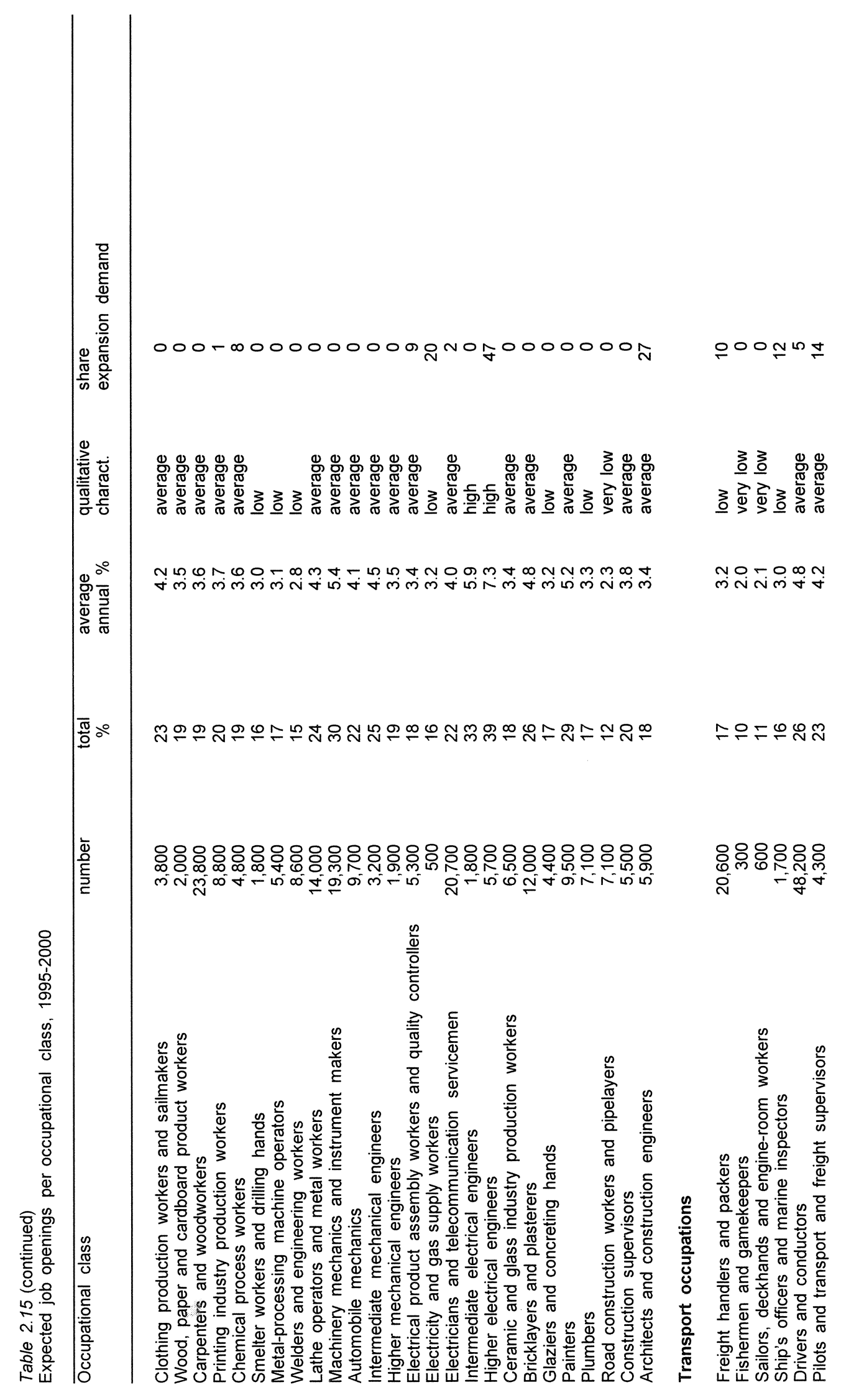




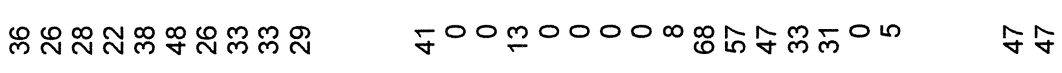

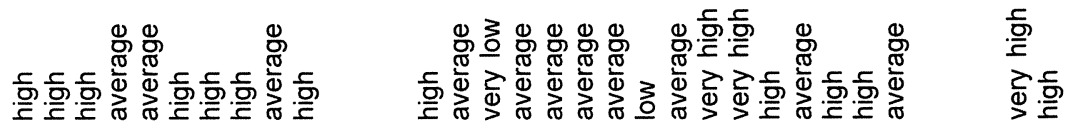

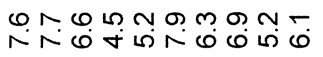

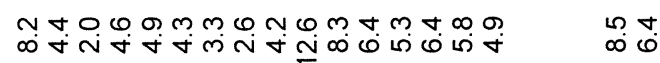

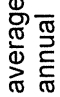

쫑ㅇำ

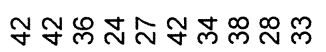

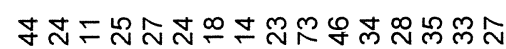

भ요

\begin{tabular}{l} 
온 \\
임 \\
\hline
\end{tabular}

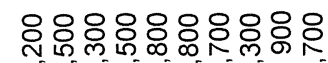

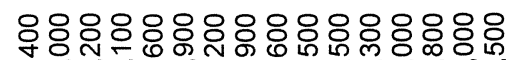

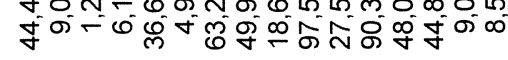

$8:$

俩

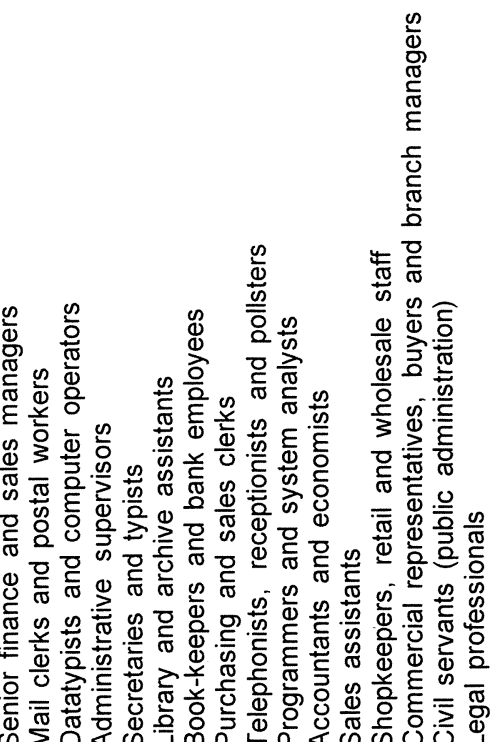

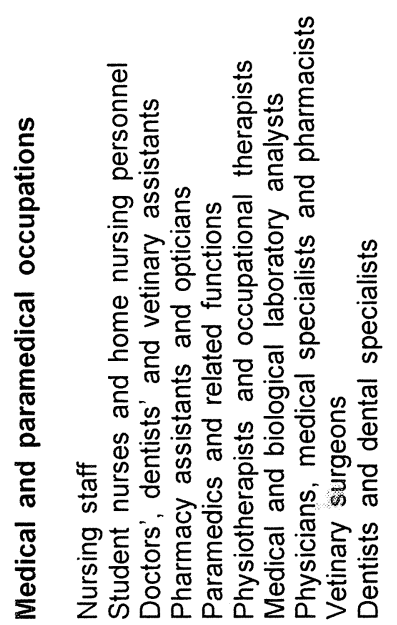

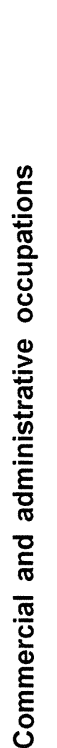

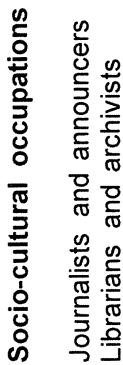




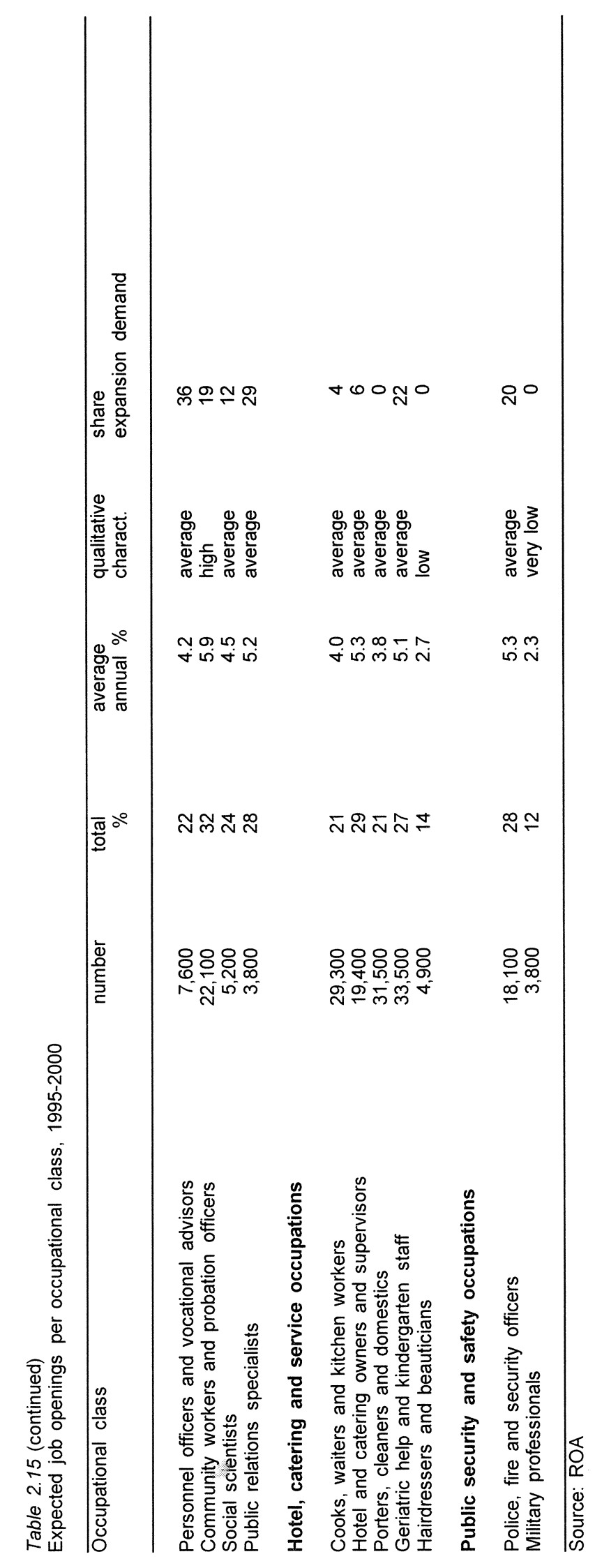


3 INFORMATION ON TYPES OF EDUCATION 

Figure 3.1

Expected job openings broken down into expansion and replacement demand per educational category, 1995-2000 (average annual percentage)

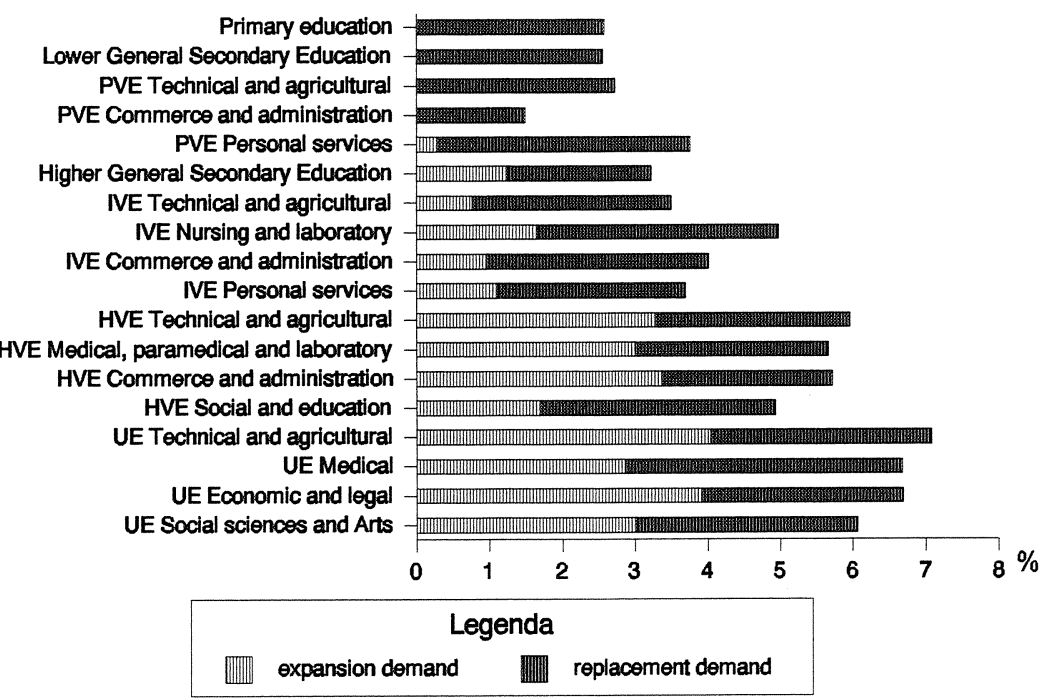

Source: ROA

Figure 3.2

Expected flows of school-leavers entering the labour market per educational category, 1995-2000 (average annual percentage)

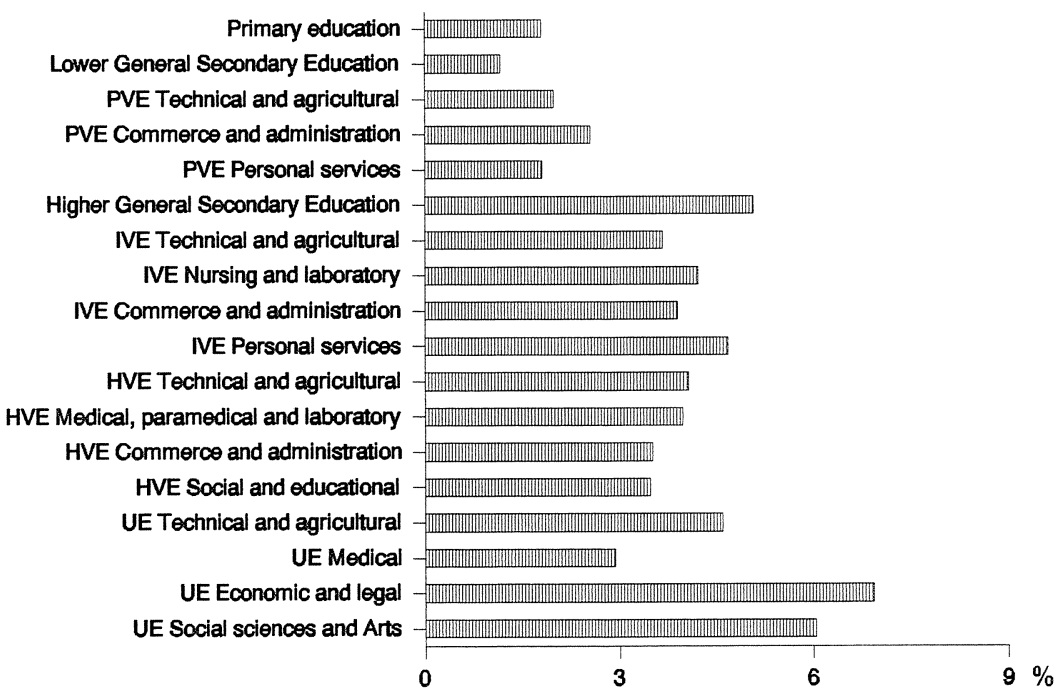

Source: ROA 
Figure 3.3

Labour market prospects for school-leavers per educational category, in 2000

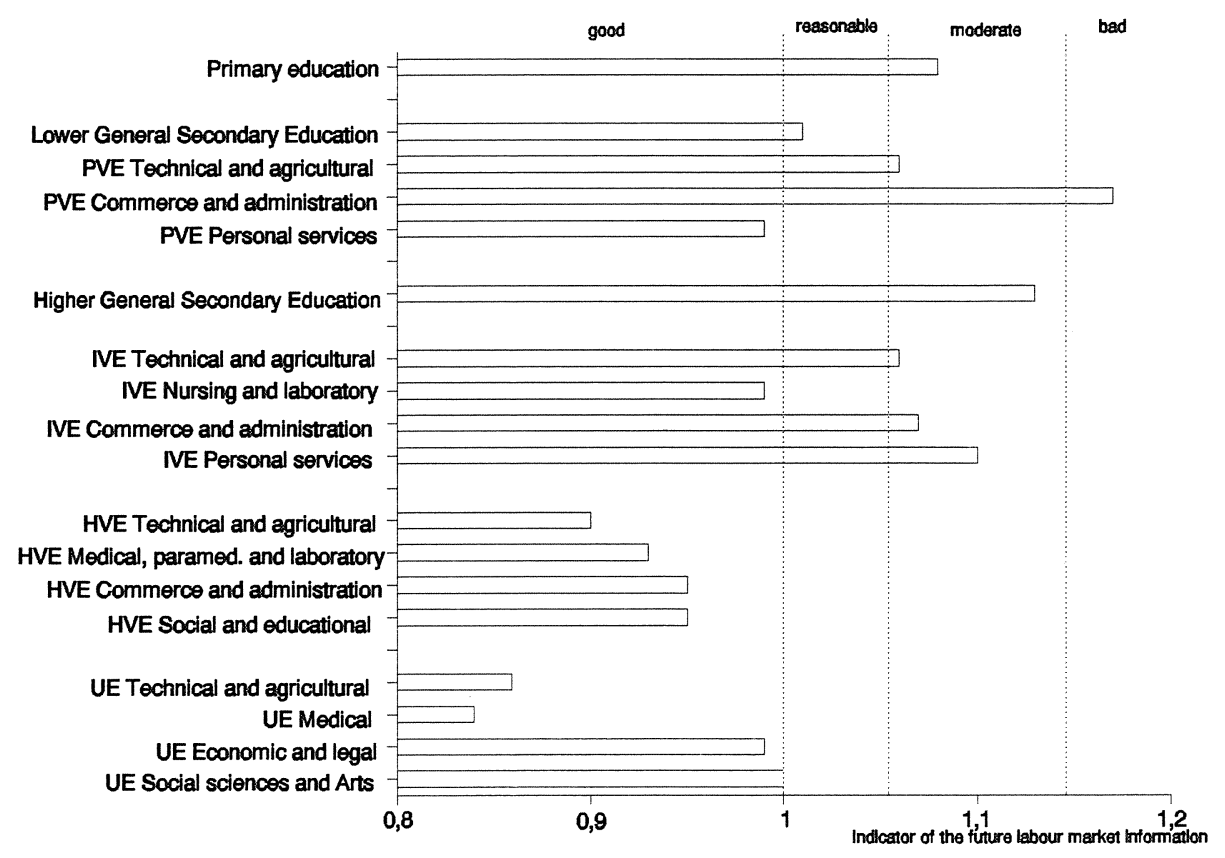

Source: ROA 
Table 3.1

Participation of school-leavers in further education per field of study, 1994

\begin{tabular}{lllll}
\hline Type of education and field of study & $\begin{array}{c}\text { study } \\
\%\end{array}$ & $\begin{array}{l}\text { qualitative } \\
\text { charact. }\end{array}$ & $\begin{array}{l}\text { apprent./ } \\
\text { in-service } \%\end{array}$ & $\begin{array}{l}\text { qualitative } \\
\text { charact. }\end{array}$ \\
\hline
\end{tabular}

\section{LGSE, PVE}

\begin{tabular}{|c|c|c|c|c|}
\hline Lower General Secondary Education & 91 & very high & 4 & average \\
\hline PVE Agriculture & 70 & very high & 19 & average \\
\hline $\begin{array}{l}\text { PVE Technical } \\
\text { PVE Construction trades } \\
\text { PVE Utilities installation } \\
\text { PVE Mechanical trades } \\
\text { PVE Automobile trades } \\
\text { PVE Electrical trades } \\
\text { PVE Printing trades } \\
\text { PVE Food trades } \\
\text { PVE Textile and leather trades }\end{array}$ & $\begin{array}{l}37 \\
42 \\
45 \\
42 \\
66 \\
64 \\
42 \\
55\end{array}$ & $\begin{array}{l}\text { average } \\
\text { average } \\
\text { high } \\
\text { average } \\
\text { very high } \\
\text { high } \\
\text { average } \\
\text { high }\end{array}$ & $\begin{array}{l}43 \\
46 \\
40 \\
45 \\
26 \\
21 \\
39 \\
18\end{array}$ & $\begin{array}{l}\text { very high } \\
\text { very high } \\
\text { high } \\
\text { very high } \\
\text { high } \\
\text { average } \\
\text { high } \\
\text { average }\end{array}$ \\
\hline $\begin{array}{l}\text { PVE Commerce and administration } \\
\text { PVE Office administration } \\
\text { PVE Retailing }\end{array}$ & $\begin{array}{l}78 \\
71\end{array}$ & $\begin{array}{l}\text { very high } \\
\text { very high }\end{array}$ & $\begin{array}{r}9 \\
13\end{array}$ & $\begin{array}{l}\text { average } \\
\text { average }\end{array}$ \\
\hline $\begin{array}{l}\text { PVE Personal services } \\
\text { PVE Community care, hotel and catering } \\
\text { PVE Beauticians and hairdressing }\end{array}$ & $\begin{array}{l}74 \\
39\end{array}$ & $\begin{array}{l}\text { very high } \\
\text { average }\end{array}$ & $\begin{array}{l}14 \\
42\end{array}$ & $\begin{array}{l}\text { average } \\
\text { very high }\end{array}$ \\
\hline HGSE, IVE & & & & \\
\hline $\begin{array}{l}\text { Higher General Secondary Education } \\
\text { Senior General Secondary Education } \\
\text { Pre-university Education }\end{array}$ & $\begin{array}{l}92 \\
94\end{array}$ & $\begin{array}{l}\text { very high } \\
\text { very high }\end{array}$ & $\begin{array}{l}1 \\
0\end{array}$ & $\begin{array}{l}\text { very low } \\
\text { very low }\end{array}$ \\
\hline $\begin{array}{l}\text { IVE Agriculture and the natural environment } \\
\text { SIVE Agricultural } \\
\text { IVE Agriculture-A } \\
\text { IVE Agriculture-B }\end{array}$ & $\begin{array}{l}25 \\
63 \\
11\end{array}$ & $\begin{array}{l}\text { average } \\
\text { high } \\
\text { very low }\end{array}$ & $\begin{array}{r}32 \\
0 \\
12\end{array}$ & $\begin{array}{l}\text { high } \\
\text { very low } \\
\text { average }\end{array}$ \\
\hline $\begin{array}{l}\text { IVE Technical Laboratory } \\
\text { SIVE Laboratory } \\
\text { IVE Chemical laboratory }\end{array}$ & $\begin{array}{l}25 \\
45\end{array}$ & $\begin{array}{l}\text { average } \\
\text { high }\end{array}$ & $\begin{array}{l}2 \\
0\end{array}$ & $\begin{array}{l}\text { low } \\
\text { very low }\end{array}$ \\
\hline $\begin{array}{l}\text { IVE Technical } \\
\text { SIVE Metalworking } \\
\text { SIVE Automobile technology } \\
\text { SIVE Electrical technology } \\
\text { SIVE Food technology } \\
\text { IVE Construction technology } \\
\text { IVE Civil engineering } \\
\text { IVE Metalworking } \\
\text { IVE Mechanical engineering } \\
\text { IVE Automobile technology } \\
\text { IVE Electrical technology } \\
\text { IVE Process technologies } \\
\text { IVE Textile and leather technology }\end{array}$ & $\begin{array}{l}18 \\
16 \\
28 \\
20 \\
43 \\
33 \\
35 \\
45 \\
43 \\
46 \\
52 \\
27\end{array}$ & $\begin{array}{l}\text { low } \\
\text { low } \\
\text { average } \\
\text { low } \\
\text { high } \\
\text { average } \\
\text { average } \\
\text { high } \\
\text { high } \\
\text { high } \\
\text { high } \\
\text { average }\end{array}$ & $\begin{array}{r}10 \\
38 \\
27 \\
40 \\
1 \\
0 \\
2 \\
1 \\
2 \\
2 \\
0 \\
2\end{array}$ & $\begin{array}{l}\text { average } \\
\text { high } \\
\text { high } \\
\text { high } \\
\text { very low } \\
\text { very low } \\
\text { low } \\
\text { very low } \\
\text { low } \\
\text { low } \\
\text { very low } \\
\text { low }\end{array}$ \\
\hline IVE Transport and harbour & 25 & average & 1 & very low \\
\hline $\begin{array}{l}\text { IVE Nursing and paramedical services } \\
\text { IVE Nursing and home care } \\
\text { IVE Medical assistant }\end{array}$ & $\begin{array}{l}49 \\
44\end{array}$ & $\begin{array}{l}\text { high } \\
\text { high }\end{array}$ & $\begin{array}{r}24 \\
9\end{array}$ & $\begin{array}{l}\text { high } \\
\text { average }\end{array}$ \\
\hline
\end{tabular}


Table 3.1 (continued)

Participation of school-leavers in further education per field of study, 1994

\begin{tabular}{|c|c|c|c|c|}
\hline Type of education and field of study & $\begin{array}{c}\text { study } \\
\%\end{array}$ & $\begin{array}{l}\text { qualitative } \\
\text { charact. }\end{array}$ & $\begin{array}{l}\text { apprent./ } \\
\text { in-service \% }\end{array}$ & $\begin{array}{l}\text { qualitative } \\
\text { charact. }\end{array}$ \\
\hline IVE Medical laboratory & 27 & average & 5 & average \\
\hline $\begin{array}{l}\text { IVE Commerce and administration } \\
\text { SIVE Retail } \\
\text { SIVE Administration } \\
\text { IVE Retail } \\
\text { IVE Administration } \\
\text { IVE Commerce } \\
\text { IVE Secretarial }\end{array}$ & $\begin{array}{l}27 \\
34 \\
32 \\
61 \\
50 \\
25\end{array}$ & $\begin{array}{l}\text { average } \\
\text { average } \\
\text { average } \\
\text { high } \\
\text { high } \\
\text { average }\end{array}$ & $\begin{array}{r}13 \\
8 \\
2 \\
1 \\
2 \\
1\end{array}$ & $\begin{array}{l}\text { average } \\
\text { average } \\
\text { low } \\
\text { very low } \\
\text { low } \\
\text { very low }\end{array}$ \\
\hline IVE Legal and fiscal & 54 & high & 0 & very low \\
\hline IVE Social and cultural & 62 & high & 2 & low \\
\hline $\begin{array}{l}\text { IVE Personal services } \\
\text { SIVE Community care } \\
\text { IVE Social services } \\
\text { IVE Community care } \\
\text { IVE Fashion and clothing } \\
\text { IVE Activities supervision }\end{array}$ & $\begin{array}{l}31 \\
41 \\
11 \\
40 \\
27\end{array}$ & $\begin{array}{l}\text { average } \\
\text { average } \\
\text { very low } \\
\text { average } \\
\text { average }\end{array}$ & $\begin{array}{r}28 \\
11 \\
31 \\
5 \\
3\end{array}$ & $\begin{array}{l}\text { high } \\
\text { average } \\
\text { high } \\
\text { average } \\
\text { average }\end{array}$ \\
\hline $\begin{array}{l}\text { IVE Hotel, catering and hairdressing } \\
\text { IVE Hotel and catering } \\
\text { IVE Building and food serv. maintenance } \\
\text { IVE Beauticians and hairdressing }\end{array}$ & $\begin{array}{l}29 \\
33 \\
22\end{array}$ & $\begin{array}{l}\text { average } \\
\text { average } \\
\text { average }\end{array}$ & $\begin{array}{l}0 \\
8 \\
6\end{array}$ & $\begin{array}{l}\text { very low } \\
\text { average } \\
\text { average }\end{array}$ \\
\hline HVE & & & & \\
\hline $\begin{array}{l}\text { HVE Teacher training } \\
\text { HVE Primary school teacher } \\
\text { HVE Agricultural teacher } \\
\text { HVE Art and self-expression teacher } \\
\text { HVE Secondary school teacher }\end{array}$ & $\begin{array}{r}9 \\
5 \\
20 \\
15\end{array}$ & $\begin{array}{l}\text { very low } \\
\text { very low } \\
\text { low } \\
\text { low }\end{array}$ & na & \\
\hline HVE Interpreter and translator & 31 & average & & \\
\hline HVE Agriculture & 17 & low & na & \\
\hline HVE Technical laboratory & 23 & average & & \\
\hline $\begin{array}{l}\text { HVE Technical } \\
\text { HVE Construction and civil engineering } \\
\text { HVE Mechanical engineering } \\
\text { HVE Electronic technology }\end{array}$ & $\begin{array}{l}17 \\
13 \\
16\end{array}$ & $\begin{array}{l}\text { low } \\
\text { low } \\
\text { low }\end{array}$ & & \\
\hline HVE Transport and harbour & 8 & very low & & \\
\hline HVE Medical analysis & 8 & very low & na & na \\
\hline $\begin{array}{l}\text { HVE Nursing and paramedical services } \\
\text { HVE Nursing } \\
\text { HVE Occupational and physiotherapy }\end{array}$ & $\begin{array}{r}12 \\
9\end{array}$ & $\begin{array}{l}\text { low } \\
\text { very low }\end{array}$ & & \\
\hline
\end{tabular}


Table 3.1 (continued)

Participation of school-leavers in further education per field of study, 1994

\begin{tabular}{|c|c|c|c|c|}
\hline Type of education and field of study & $\begin{array}{c}\text { study } \\
\%\end{array}$ & $\begin{array}{l}\text { qualitative } \\
\text { charact. }\end{array}$ & $\begin{array}{l}\text { apprent./ } \\
\text { in-service \% }\end{array}$ & $\begin{array}{l}\text { qualitative } \\
\text { charact. }\end{array}$ \\
\hline $\begin{array}{l}\text { HVE Commerce and administration } \\
\text { HVE Business administration } \\
\text { HVE Accounting } \\
\text { HVE Commercial information science } \\
\text { HVE Tourism } \\
\text { HVE Commerce }\end{array}$ & $\begin{array}{r}22 \\
2 \\
19 \\
14 \\
21\end{array}$ & $\begin{array}{l}\text { average } \\
\text { very low } \\
\text { low } \\
\text { low } \\
\text { average }\end{array}$ & & \\
\hline HVE Business administration technology & 23 & average & & \\
\hline HVE Legal and fiscal & 30 & average & & \\
\hline $\begin{array}{l}\text { HVE Social and cultural } \\
\text { HVE Welfare and social work } \\
\text { HVE Personnel management } \\
\text { HVE Journalism }\end{array}$ & $\begin{array}{l}12 \\
12 \\
15\end{array}$ & $\begin{array}{l}\text { low } \\
\text { low } \\
\text { low }\end{array}$ & & \\
\hline HVE Fine Arts & 9 & very low & & \\
\hline
\end{tabular}

Source: RUBS/HBO Monitor/ROA 
Table 3.2

Number of workers per type of education, average 1993-1994

Type of education number of workers trend

1992-'94

Primary Education

Primary Education

508,000

falling

LGSE, PVE

Lower General Secondary Education

408,500

78,000

PVE Agriculture

136,500

PVE Construction trades

11,000

PVE Utilities installation

139,000

PVE Mechanical trades

PVE Automobile trades

46,500

PVE Electrical trades

61,500

7,500

PVE Food trades

21,500

PVE Textile and leather trades

23,000

PVE Transport and harbour $\quad 35,500$

PVE Administration $\quad 60,500$

PVE Commerce

PVE Community care, hotel and catering

32,500

PVE Security

199,500

9,000

constant

falling strongly

$-$

constant

falling strongly

falling strongly

falling

falling

falling

falling

constant

rising strongly

HGSE, IVE

Higher General Secondary Education

294,000

IVE Agriculture and the natural environment 133,000

IVE Technical Laboratory

13,500

IVE Construction technology

162,500

IVE Civil engineering

20,500

IVE Metalworking

60,000

IVE Precision engineering

15,000

IVE Mechanical engineering

87,500

IVE Automobile technology

62,000

IVE Electrical technology

143,000

IVE Printing technology

37,000

IVE Food technology

IVE Process technologies

37,500

17,500

35,000

Prochnology

48,000

IVE Transport and harbour

183,500

Tervices

28,000

IVE Medical laboratory

314,000

IVE Administration

94,500

IVE Tourism and recreation $\quad 15,000$

IVE Commerce $\quad 33,000$

IVE Secretarial

94,500

IVE Legal and fiscal

44,500

52,500

IVE Community care

212,500

IVE Hotel, catering and hairdressing

53,000

IVE Police, fire and defense

82,500

rising

rising strongly

rising

falling

rising

constant

falling

-

rising

rising

rising strongly

rising strongly

rising

rising

constant

rising strongly

constant 
Table 3.2 (continued)

Number of workers per type of education, average 1993-1994

\begin{tabular}{lll}
\hline Type of education & number of workers & trend \\
$1992-' 94$
\end{tabular}

1992-'94

\section{HVE}

HVE Teacher training

HVE Interpreter and translator

HVE Agriculture and environmental science

HVE Technical laboratory

HVE Construction and civil engineering

HVE Mechanical engineering

HVE Electronic and information technology

HVE Transport and harbour

HVE Medical laboratory

HVE Nursing and paramedical services

HVE Business administration

HVE Accounting

HVE Commercial information science

HVE Tourism and recreation

HVE Commerce

HVE Business administration technology

HVE Legal and fiscal

HVE Social and cultural

HVE Fine Arts

HVE Police, fire and defense

UE

UE Arts

UE Theology

UE Agriculture and environmental science

UE Mathematics and natural sciences

UE Construction and civil engineering

UE Mechanical engineering

UE Electrical engineering and information technology

UE Veterinary and medical sciences and dentistry

UE Pharmacy

UE Economics, econometrics and business administration

UE Management science

UE Information science

UE Law

UE Public administration

UE Social sciences

UE Fine Arts
258,500

7,500

20,000

26,500

34,000

29,500

39,000

26,500

20,500

84,000

21,500

26,000

7,500

19,000

13,000

25,500

118,000

41,000

9,000

40,500

6,000

12,000

39,000

18,000

8,500

12,500

51,500

5,500

40,500

11,000

4,500

46,500

10,000

81,500

8,500 constant

rising strongly

constant

constant

rising

rising

constant

rising

rising strongly

rising

rising

rising strongly

constant

rising strongly

falling strongly
rising strongly
rising
-
constant
rising strongly
rising
-
-
falling
-
-
rising strongly
constant

falling strongly

rising strongly

rising

constant

rising strongly

rising

constant

Source: CBS/ROA 
Table 3.3

Percentage of women per type of education, average 1993-1994

\begin{tabular}{llll}
\hline Type of education & $\%$ & $\begin{array}{l}\text { qualitative } \\
\text { charact. }\end{array}$ & $\begin{array}{c}\text { trend } \\
1992-' 94\end{array}$ \\
\hline
\end{tabular}

\section{Primary Education}

Primary Education

LGSE, PVE

\author{
Lower General Secondary Education \\ PVE Agriculture \\ PVE Construction trades \\ PVE Utilities installation \\ PVE Mechanical trades \\ PVE Automobile trades \\ PVE Electrical trades \\ PVE Printing trades \\ PVE Food trades \\ PVE Textile and leather trades \\ PVE Transport and harbour \\ PVE Administration \\ PVE Commerce \\ PVE Community care, hotel and catering \\ PVE Security
}

HGSE, IVE

Higher General Secondary Education

IVE Agriculture and the natural environment

IVE Technical Laboratory

IVE Construction technology

IVE Civil engineering

IVE Metalworking

IVE Precision engineering

IVE Mechanical engineering

IVE Automobile technology

IVE Electrical technology

IVE Printing technology

IVE Food technology

IVE Process technologies

IVE Textile and leather technology

IVE Transport and harbour

IVE Nursing and paramedical services

IVE Medical laboratory

IVE Retail

IVE Administration

IVE Tourism and recreation

IVE Commerce

IVE Secretarial

IVE Legal and fiscal

IVE Social and cultural

IVE Community care

IVE Hotel, catering and hairdressing

IVE Police, fire and defense

$\begin{array}{rll}49 & \text { average } & - \\ 8 & \text { very low } & - \\ . & \text { very low } & - \\ . & \text { very low } & - \\ . & \text { very low } & - \\ . & \text { very low } & - \\ . & \text { very low } & - \\ . & \text { low } & - \\ 12 & \text { low } & \text { rising strongly } \\ 76 & \text { very high } & \text { constant } \\ 61 & \text { very low } & - \\ 63 & \text { high } & - \\ 90 & \text { high } & - \\ . & \text { very high } & \text { constant } \\ & \text { very low } & -\end{array}$

$\begin{array}{rll}46 & \text { average } & \text { rising } \\ 12 & \text { low } & \text { rising } \\ 41 & \text { average } & \text { rising strongly } \\ . & \text { very low } & - \\ . & \text { very low } & - \\ . & \text { very low } & - \\ . & \text { low } & - \\ . & - & - \\ . & - & - \\ . & \text { very low } & - \\ 11 & \text { low } & - \\ 8 & \text { very low } & - \\ . & \text { very low } & - \\ 77 & \text { very high } & - \\ 10 & \text { very low } & \text { rising } \\ 89 & \text { very high } & - \\ 75 & \text { high } & - \\ 40 & \text { average } & - \\ 31 & \text { average } & \text { rising } \\ 87 & \text { very high } & \text { constant } \\ 33 & \text { average } & \text { rising strongly } \\ 97 & \text { very high } & \text { constant } \\ 26 & \text { average } & \text { rising } \\ 68 & \text { high } & \text { constant } \\ 81 & \text { very high } & \text { constant } \\ 51 & \text { high } & - \\ 6 & \text { very low } & -\end{array}$


Table 3.3 (continued)

Percentage of women per type of education, average 1993-1994

\begin{tabular}{llll}
\hline Type of education & $\%$ & $\begin{array}{l}\text { qualitative } \\
\text { charact. }\end{array}$ & $\begin{array}{l}\text { trend } \\
1992-94\end{array}$ \\
\hline
\end{tabular}

HVE

HVE Teacher training

HVE Interpreter and translator

HVE Agriculture and environmental science

HVE Technical laboratory

HVE Construction and civil engineering

HVE Mechanical engineering

HVE Electronic and information technology

HVE Transport and harbour

HVE Medical laboratory

HVE Nursing and paramedical services

HVE Business administration

HVE Accounting

HVE Commercial information science

HVE Tourism and recreation

HVE Commerce

HVE Business administration technology

HVE Legal and fiscal

HVE Social and cultural

HVE Fine Arts

HVE Police, fire and defense

UE

\section{UE Arts}

UE Theology

UE Agriculture and environmental science

UE Mathematics and natural sciences

UE Construction and civil engineering

UE Mechanical engineering

UE Electrical engineering and information technology

UE Veterinary and medical sciences and dentistry

UE Pharmacy

UE Economics, econometrics and business administration

UE Management science

UE Information science

UE Law

UE Public administration

UE Social sciences

UE Fine Arts
55

$\begin{array}{ll}\text { high } & - \\ \text { high } & - \\ \text { low } & - \\ \text { average } & \text { rising } \\ \text { very low } & - \\ \text { very low } & - \\ \text { very low } & - \\ \text { very low } & - \\ \text { high } & \text { constant } \\ \text { high } & - \\ \text { low } & - \\ \text { very low } & - \\ \text { low } & - \\ \text { very high } & \text { rising } \\ \text { low } & - \\ \text { very low } & - \\ \text { low } & \text { rising strongly } \\ \text { high } & \text { rising } \\ \text { average } & \text { rising } \\ \text { very low } & -\end{array}$

$\begin{array}{rll}48 & \text { average } & \text { falling } \\ 21 & \text { low } & - \\ 14 & \text { low } & \text { rising strongly } \\ . & \text { low } & - \\ . & \text { very low } & - \\ . & \text { very low } & - \\ 30 & \text { very low } & - \\ . & \text { average } & - \\ 11 & \text { average } & - \\ . & \text { low } & \text { rising } \\ 37 & \text { low } & - \\ 30 & \text { very low } & - \\ 47 & \text { average } & \text { rising } \\ 41 & \text { average } & - \\ & \text { average } & \text { rising }\end{array}$

Source: CBS/ROA 
Table 3.4

Percentage of working school-leavers who are female per field of study, 1994

\begin{tabular}{|c|c|c|}
\hline Type of education and field of study & $\%$ & qualitative charact. \\
\hline LGSE, PVE & & \\
\hline Lower General Secondary Education & 61 & average \\
\hline PVE Agriculture & 40 & average \\
\hline $\begin{array}{l}\text { PVE Technical } \\
\text { PVE Construction trades } \\
\text { PVE Utilities installation } \\
\text { PVE Mechanical trades } \\
\text { PVE Automobile trades } \\
\text { PVE Electrical trades } \\
\text { PVE Printing trades } \\
\text { PVE Food trades } \\
\text { PVE Textile and leather trades }\end{array}$ & $\begin{array}{r}0 \\
3 \\
3 \\
5 \\
20 \\
97\end{array}$ & $\begin{array}{l}\text { very low } \\
\text { very low } \\
\text { very low } \\
\text { very low } \\
\text { very low } \\
\text { low } \\
\text { low } \\
\text { high }\end{array}$ \\
\hline $\begin{array}{l}\text { PVE Commerce and administration } \\
\text { PVE Office administration } \\
\text { PVE Retailing }\end{array}$ & $\begin{array}{l}81 \\
65\end{array}$ & $\begin{array}{l}\text { high } \\
\text { average }\end{array}$ \\
\hline $\begin{array}{l}\text { PVE Personal services } \\
\text { PVE Community care, hotel and catering } \\
\text { PVE Beauticians and hairdressing }\end{array}$ & $\begin{array}{r}94 \\
100\end{array}$ & $\begin{array}{l}\text { high } \\
\text { very high }\end{array}$ \\
\hline HGSE, IVE & & \\
\hline $\begin{array}{l}\text { Higher General Secondary Education } \\
\text { Senior General Secondary Education } \\
\text { Pre-university Education }\end{array}$ & . & $\begin{array}{l}\text { average } \\
\text { average }\end{array}$ \\
\hline $\begin{array}{l}\text { IVE Agriculture and the natural environment } \\
\text { SIVE Agricultural } \\
\text { IVE Agriculture-A } \\
\text { IVE Agriculture-B }\end{array}$ & $\begin{array}{r}49 \\
16\end{array}$ & $\begin{array}{l}\text { average } \\
\text { very low } \\
\text { low }\end{array}$ \\
\hline $\begin{array}{l}\text { IVE Technical Laboratory } \\
\text { SIVE Laboratory } \\
\text { IVE Chemical laboratory }\end{array}$ & $\begin{array}{l}77 \\
59\end{array}$ & $\begin{array}{l}\text { high } \\
\text { average }\end{array}$ \\
\hline $\begin{array}{l}\text { IVE Technical } \\
\text { SIVE Metalworking } \\
\text { SIVE Automobile technology } \\
\text { SIVE Electrical technology } \\
\text { SIVE Food technology } \\
\text { IVE Construction technology } \\
\text { IVE Civil engineering } \\
\text { IVE Metalworking } \\
\text { IVE Mechanical engineering } \\
\text { IVE Automobile technology } \\
\text { IVE Electrical technology } \\
\text { IVE Process technologies } \\
\text { IVE Textile and leather technology }\end{array}$ & $\begin{array}{r}2 \\
18 \\
0 \\
33 \\
22 \\
6 \\
2 \\
2 \\
4 \\
5 \\
9 \\
95\end{array}$ & $\begin{array}{l}\text { very low } \\
\text { low } \\
\text { very low } \\
\text { low } \\
\text { low } \\
\text { very low } \\
\text { low } \\
\text { very low } \\
\text { very low } \\
\text { very low } \\
\text { very low } \\
\text { high }\end{array}$ \\
\hline IVE Transport and harbour & 9 & very low \\
\hline $\begin{array}{l}\text { IVE Nursing and paramedical services } \\
\text { IVE Nursing and home care } \\
\text { IVE Medical assistant }\end{array}$ & $\begin{array}{l}93 \\
97\end{array}$ & $\begin{array}{l}\text { high } \\
\text { high }\end{array}$ \\
\hline
\end{tabular}


Table 3.4 (continued)

Percentage of working school-leavers who are female per field of study, 1994

\begin{tabular}{|c|c|c|}
\hline Type of education and field of study & $\%$ & qualitative charact. \\
\hline IVE Medical laboratory & 89 & high \\
\hline $\begin{array}{l}\text { IVE Commerce and administration } \\
\text { SIVE Retail } \\
\text { SIVE Administration } \\
\text { IVE Retail } \\
\text { IVE Administration } \\
\text { IVE Commerce } \\
\text { IVE Secretarial }\end{array}$ & $\begin{array}{r}64 \\
88 \\
67 \\
68 \\
85 \\
100\end{array}$ & $\begin{array}{l}\text { average } \\
\text { high } \\
\text { average } \\
\text { average } \\
\text { high } \\
\text { very high }\end{array}$ \\
\hline IVE Legal and fiscal & 80 & high \\
\hline IVE Social and cultural & 89 & high \\
\hline $\begin{array}{l}\text { IVE Personal services } \\
\text { SIVE Community care } \\
\text { IVE Social services } \\
\text { IVE Community care } \\
\text { IVE Fashion and clothing } \\
\text { IVE Activities supervision }\end{array}$ & $\begin{array}{l}96 \\
95 \\
99 \\
96 \\
97\end{array}$ & $\begin{array}{l}\text { high } \\
\text { high } \\
\text { very high } \\
\text { high } \\
\text { high }\end{array}$ \\
\hline $\begin{array}{l}\text { IVE Hotel, catering and hairdressing } \\
\text { IVE Hotel and catering } \\
\text { IVE Building and food service maintenance } \\
\text { IVE Beauticians and hairdressing }\end{array}$ & $\begin{array}{r}61 \\
69 \\
100\end{array}$ & $\begin{array}{l}\text { average } \\
\text { average } \\
\text { very high }\end{array}$ \\
\hline HVE & & \\
\hline $\begin{array}{l}\text { HVE Teacher training } \\
\text { HVE Primary school teacher } \\
\text { HVE Agricultural teacher } \\
\text { HVE Art and self-expression teacher } \\
\text { HVE Secondary school teacher }\end{array}$ & $\begin{array}{l}90 \\
35 \\
62 \\
71\end{array}$ & $\begin{array}{l}\text { high } \\
\text { low } \\
\text { average } \\
\text { average }\end{array}$ \\
\hline HVE Interpreter and translator & 81 & high \\
\hline HVE Agriculture & 22 & low \\
\hline HVE Technical laboratory & 47 & average \\
\hline $\begin{array}{l}\text { HVE Technical } \\
\text { HVE Construction and civil engineering } \\
\text { HVE Mechanical engineering } \\
\text { HVE Electronic technology }\end{array}$ & $\begin{array}{r}17 \\
6 \\
4\end{array}$ & $\begin{array}{l}\text { low } \\
\text { very low } \\
\text { very low }\end{array}$ \\
\hline HVE Transport and harbour & 7 & very low \\
\hline HVE Medical analysis & 84 & high \\
\hline $\begin{array}{l}\text { HVE Nursing and paramedical services } \\
\text { HVE Nursing } \\
\text { HVE Occupational and physiotherapy }\end{array}$ & $\begin{array}{l}88 \\
66\end{array}$ & $\begin{array}{l}\text { high } \\
\text { average }\end{array}$ \\
\hline
\end{tabular}


Table 3.4 (continued)

Percentage of working school-leavers who are female per field of study, 1994

\begin{tabular}{lll}
\hline Type of education and field of study & $\%$ & qualitative charact. \\
\hline HVE Commerce and administration & & low \\
HVE Business administration & 33 & low \\
HVE Accounting & 31 & low \\
HVE Commercial information science & 27 & high \\
HVE Tourism & 82 & average \\
HVE Commerce & 48 & low \\
HVE Business administration technology & 23 & average \\
HVE Legal and fiscal & 28 & \\
HVE Social and cultural & 48 & high \\
HVE Welfare and social work & & average \\
HVE Personnel management & 91 & average \\
HVE Journalism & 66 & average \\
HVE Fine Arts & 68 & \\
\hline
\end{tabular}

Source: RUBS/HBO Monitor/ROA 


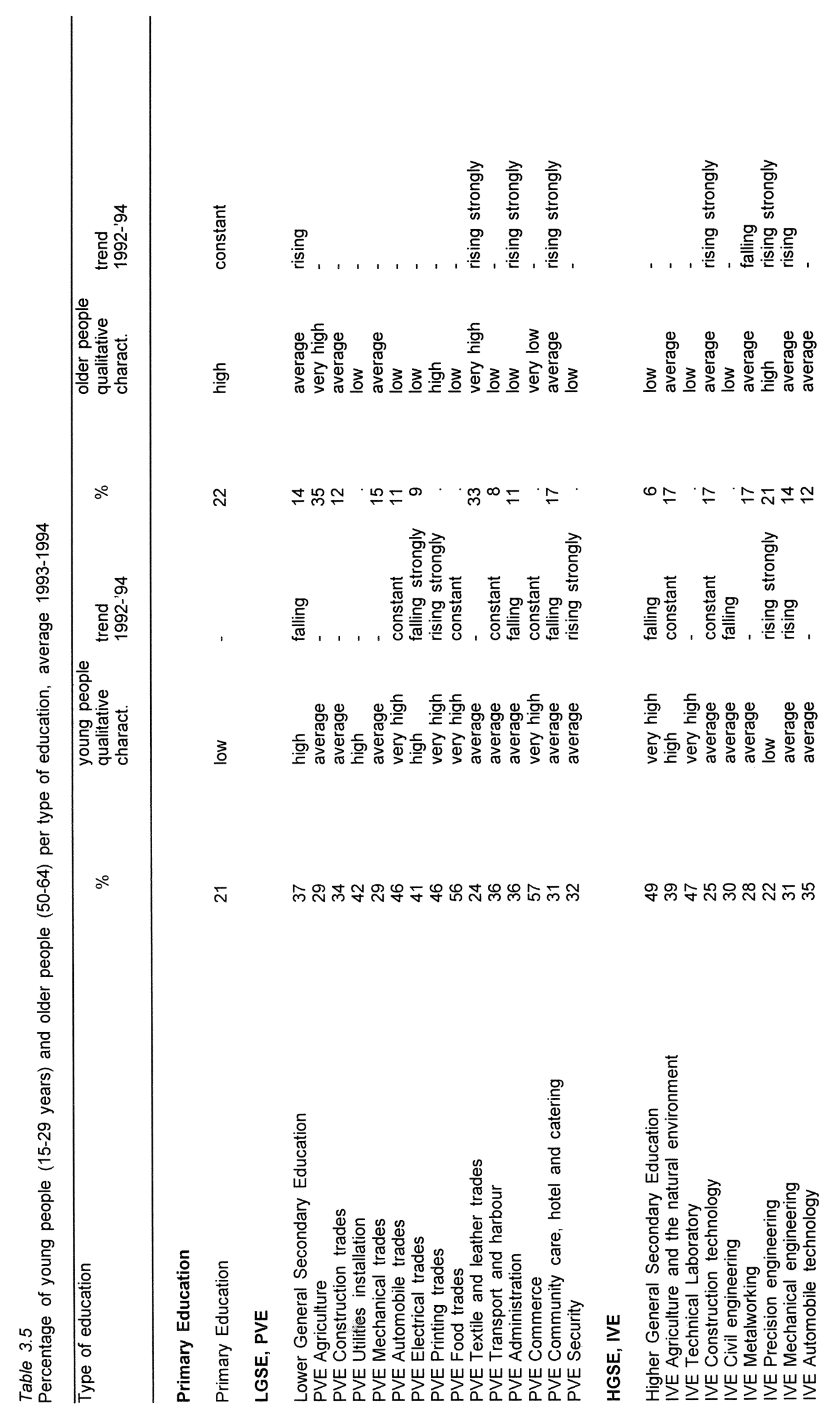




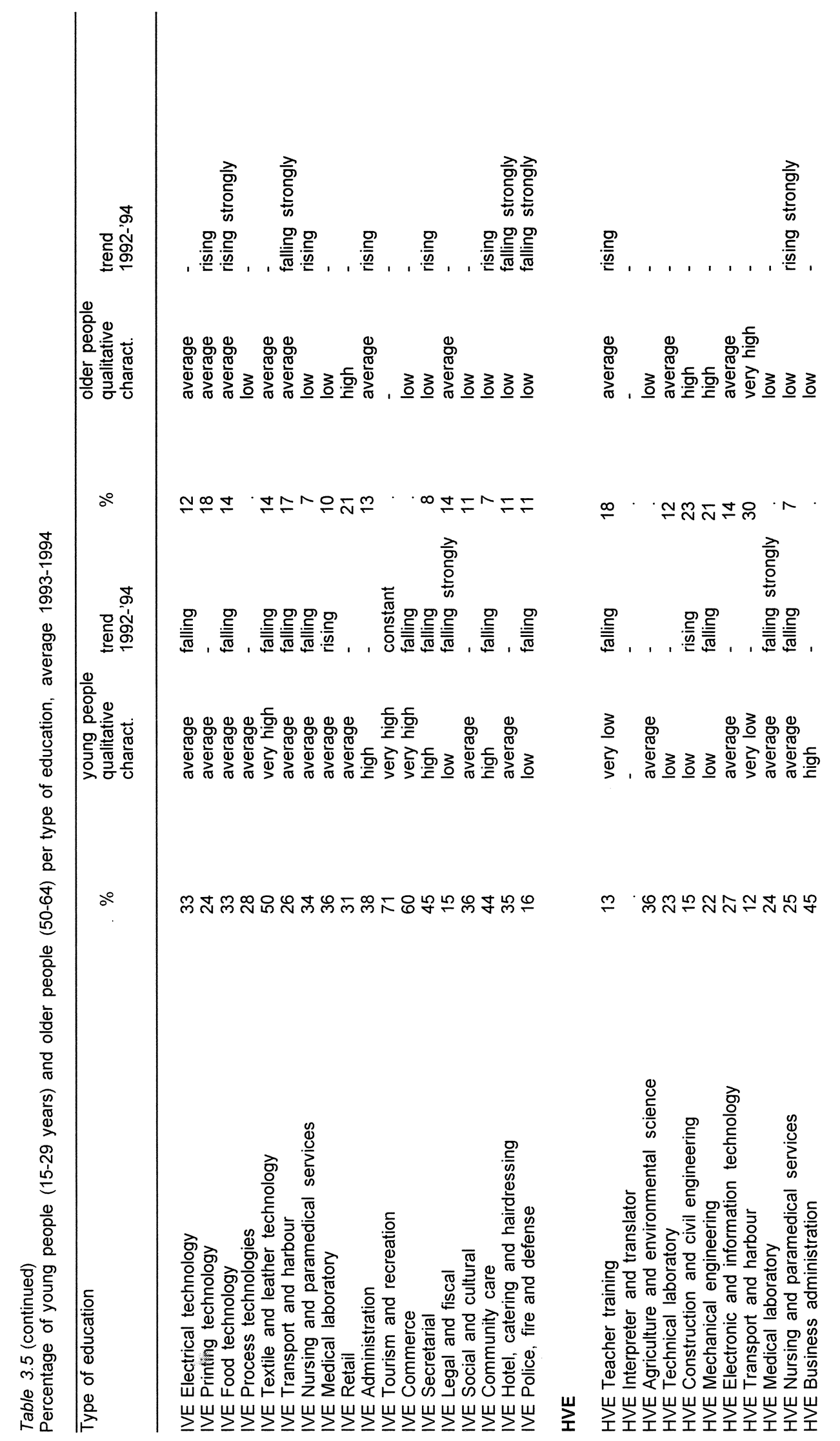




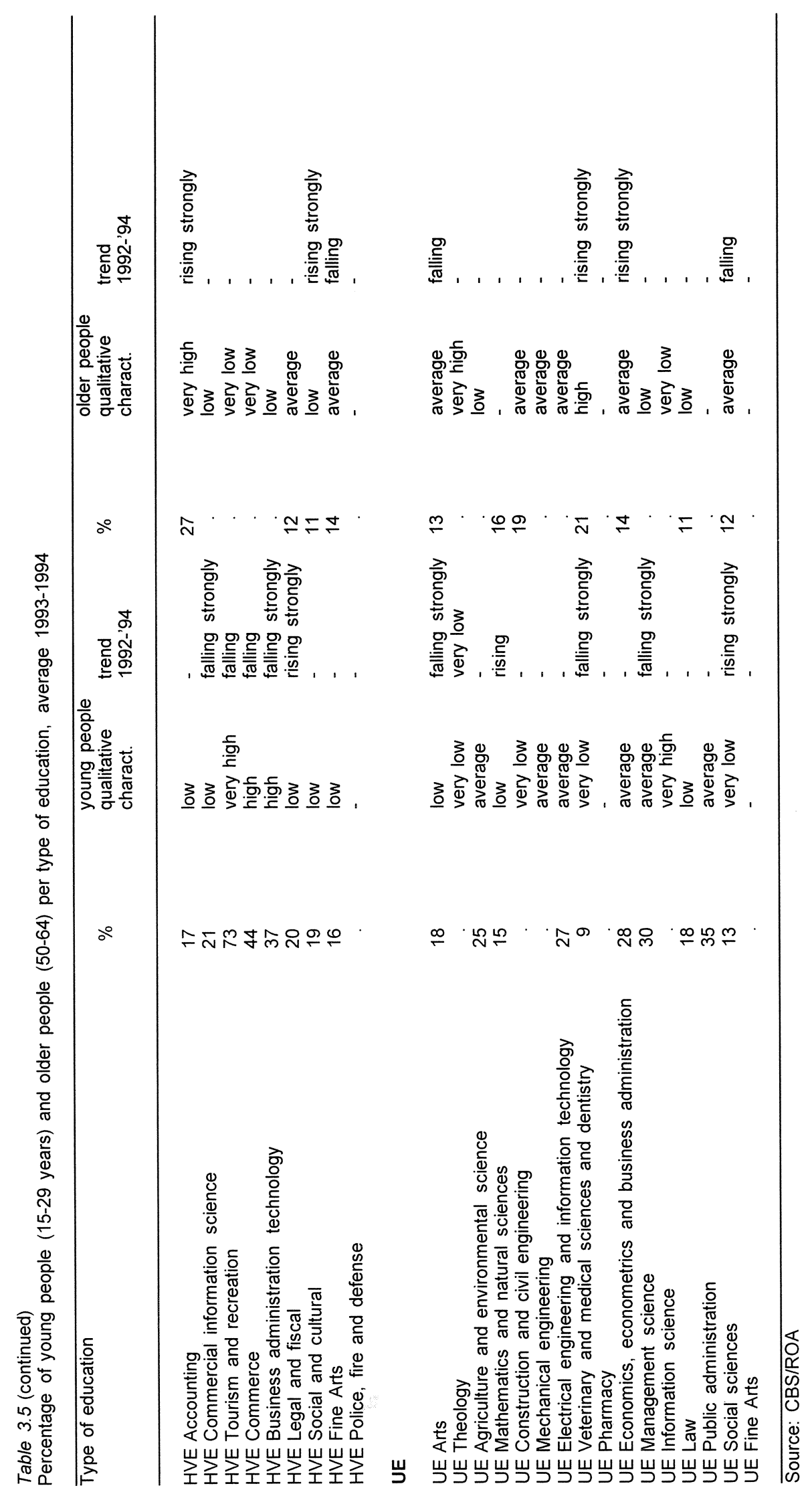


Table 3.6

Percentage of members of ethnic minorities per type of education, average 1993-1994

\begin{tabular}{llll}
\hline Type of education & $\%$ & $\begin{array}{l}\text { qualitative } \\
\text { charact. }\end{array}$ & $\begin{array}{c}\text { trend } \\
1992-' 94\end{array}$ \\
\hline
\end{tabular}

\section{Primary Education}

very high

Primary Education

11

LGSE, PVE

Lower General Secondary Education

PVE Agriculture

PVE Construction trades

PVE Utilities installation

PVE Mechanical trades

PVE Automobile trades

PVE Electrical trades

PVE Printing trades

PVE Food trades

PVE Textile and leather trades

PVE Transport and harbour

PVE Administration

PVE Commerce

PVE Community care, hotel and catering

PVE Security

HGSE, IVE

Higher General Secondary Education

IVE Agriculture and the natural environment

IVE Technical Laboratory

IVE Construction technology

IVE Civil engineering

IVE Metalworking

IVE Precision engineering

IVE Mechanical engineering

IVE Automobile technology

IVE Electrical technology

IVE Printing technology

IVE Food technology

IVE Process technologies

IVE Textile and leather technology

IVE Transport and harbour

IVE Nursing and paramedical services

IVE Medical laboratory

IVE Retail

IVE Administration

IVE Tourism and recreation

IVE Commerce

IVE Secretarial

IVE Legal and fiscal

IVE Social and cultura

IVE Community care

IVE Hotel, catering and hairdressing

IVE Police, fire and defense

$\begin{array}{ll}\text { average } & \text { rising } \\ \text { very low } & - \\ \text { low } & - \\ \text { high } & - \\ \text { high } & - \\ \text { average } & - \\ \text { very high } & - \\ \text { average } & - \\ \text { average } & - \\ \text { high } & - \\ \text { low } & - \\ \text { high } & \text { rising } \\ \text { low } & - \\ \text { very low } & - \\ \text { high } & -\end{array}$

3

average

very low

low

very low

very low

average

very low

low

average

low

average

very low

average

low

very low

low

average

low

average

average

low

average

low

average

low

low

low rising strongly$$
\text { - }
$$$$
-
$$$$
-
$$$$
\text { rising strongly }
$$$$
\text { - }
$$$$
-
$$$$
\text { - }
$$$$
\text { - }
$$$$
-
$$

rising strongly rising strongly

-

$-$

-

rising strongly 
Table 3.6 (continued)

Percentage of members of ethnic minorities per type of education, average 1993-1994

\begin{tabular}{llll}
\hline Type of education & $\%$ & $\begin{array}{l}\text { qualitative } \\
\text { charact. }\end{array}$ & $\begin{array}{l}\text { trend } \\
1992-' 94\end{array}$ \\
\hline
\end{tabular}

HVE

HVE Teacher training

3

HVE Interpreter and translator

HVE Agriculture and environmental science

HVE Technical laboratory

HVE Construction and civil engineering

HVE Mechanical engineering

HVE Electronic and information technology

HVE Transport and harbour

HVE Medical laboratory

HVE Nursing and paramedical services

HVE Business administration

HVE Accounting

HVE Commercial information science

HVE Tourism and recreation

HVE Commerce

HVE Business administration technology

HVE Legal and fisca

HVE Social and cultural

HVE Fine Arts

HVE Police, fire and defense

$\begin{array}{ll}\text { average } & \text { - } \\ \text { average } & \text { - } \\ \text { very low } & \text { - } \\ \text { low } & \text { - } \\ \text { low } & \text { - } \\ \text { low } & \text { - } \\ \text { very low } & \text { - } \\ \text { average } & \text { - } \\ \text { low } & \text { - } \\ \text { very low } & \text { - } \\ \text { low } & \text { - } \\ \text { very low } & \text { - } \\ \text { very low } & - \\ \text { very low } & - \\ \text { very low } & - \\ \text { very low } & - \\ \text { low } & - \\ \text { low } & - \\ \text { low } & - \\ \text { very low } & -\end{array}$

UE

UE Arts

UE Theology

UE Agriculture and environmental science

UE Mathematics and natural sciences

UE Construction and civil engineering

UE Mechanical engineering

UE Electrical engineering and information technology

UE Veterinary and medical sciences and dentistry

UE Pharmacy

UE Economics, econometrics and business administration

UE Management science

UE Information science

UE Law

UE Public administration

UE Social sciences

UE Fine Arts

low

very low

very low

very low

very low

low

low

very low

low

average

low

average

low

average

low

low

Source: CBS/ROA

- The percentage relates to the members of those ethnic minorities which fall under the 'Promotion of Balanced Employment Participation by Members of Ethnic Minorities Act' (Wet Bevordering Evenredige Arbeidsdeelname Allochtonen, WBEAA): i.e., those from Aruba, the Dutch Antilles, Ethiopia, Iraq, Iran, the former Yugoslavia, Morocco, Somalia, Surinam, Turkey and Vietnam. 
Table 3.7

Percentage of working school-leavers who are from ethnic minorities per field of study, 1994

\begin{tabular}{|c|c|c|}
\hline Type of education and field of study & $\%$ & qualitative charact. \\
\hline \multicolumn{3}{|l|}{ LGSE, PVE } \\
\hline Lower General Secondary Education & 3 & average \\
\hline PVE Agriculture & 0 & very low \\
\hline $\begin{array}{l}\text { PVE Technical } \\
\text { PVE Construction trades } \\
\text { PVE Utilities installation } \\
\text { PVE Mechanical trades } \\
\text { PVE Automobile trades } \\
\text { PVE Electrical trades } \\
\text { PVE Printing trades } \\
\text { PVE Food trades } \\
\text { PVE Textile and leather trades }\end{array}$ & $\begin{array}{l}0 \\
4 \\
4 \\
0 \\
0 \\
1\end{array}$ & $\begin{array}{l}\text { very low } \\
\text { very high } \\
\text { high } \\
\text { high } \\
\text { very low } \\
\text { very low } \\
\text { very low } \\
\text { low }\end{array}$ \\
\hline $\begin{array}{l}\text { PVE Commerce and administration } \\
\text { PVE Office administration } \\
\text { PVE Retailing }\end{array}$ & $\begin{array}{r}10 \\
3\end{array}$ & $\begin{array}{l}\text { very high } \\
\text { average }\end{array}$ \\
\hline $\begin{array}{l}\text { PVE Personal services } \\
\text { PVE Community care, hotel and catering } \\
\text { PVE Beauticians and hairdressing }\end{array}$ & $\begin{array}{l}1 \\
7\end{array}$ & $\begin{array}{l}\text { low } \\
\text { very high }\end{array}$ \\
\hline HGSE, IVE & & \\
\hline $\begin{array}{l}\text { Higher General Secondary Education } \\
\text { Senior General Secondary Education } \\
\text { Pre-university Education }\end{array}$ & . & $\begin{array}{l}\text { very low } \\
\text { very low }\end{array}$ \\
\hline $\begin{array}{l}\text { IVE Agriculture and the natural environment } \\
\text { SIVE Agricultural } \\
\text { IVE Agriculture-A } \\
\text { IVE Agriculture-B }\end{array}$ & $\begin{array}{l}2 \\
0\end{array}$ & $\begin{array}{l}\text { average } \\
\text { very low } \\
\text { very low }\end{array}$ \\
\hline $\begin{array}{l}\text { IVE Technical Laboratory } \\
\text { SIVE Laboratory } \\
\text { IVE Chemical laboratory }\end{array}$ & $\begin{array}{l}3 \\
1\end{array}$ & $\begin{array}{l}\text { average } \\
\text { low }\end{array}$ \\
\hline $\begin{array}{l}\text { IVE Technical } \\
\text { SIVE Metalworking } \\
\text { SIVE Automobile technology } \\
\text { SIVE Electrical technology } \\
\text { SIVE Food technology } \\
\text { IVE Construction technology } \\
\text { IVE Civil engineering } \\
\text { IVE Metalworking } \\
\text { IVE Mechanical engineering } \\
\text { IVE Automobile technology } \\
\text { IVE Electrical technology } \\
\text { IVE Process technologies } \\
\text { IVE Textile and leather technology }\end{array}$ & $\begin{array}{l}0 \\
1 \\
1 \\
0 \\
0 \\
0 \\
. \\
1 \\
1 \\
2 \\
5\end{array}$ & $\begin{array}{l}\text { very low } \\
\text { low } \\
\text { low } \\
\text { very low } \\
\text { very low } \\
\text { very low } \\
\text { very low } \\
\text { low } \\
\text { low } \\
\text { average } \\
\text { very low } \\
\text { very high }\end{array}$ \\
\hline IVE Transport and harbour & . & very low \\
\hline $\begin{array}{l}\text { IVE Nursing and paramedical services } \\
\text { IVE Nursing and home care } \\
\text { IVE Medical assistant }\end{array}$ & $\begin{array}{l}1 \\
3\end{array}$ & $\begin{array}{l}\text { low } \\
\text { average }\end{array}$ \\
\hline
\end{tabular}


Table 3.7 (continued)

Percentage of working school-leavers who are from ethnic minorities per field of study, 1994

\begin{tabular}{|c|c|c|}
\hline Type of education and field of study & $\%$ & qualitative charact. \\
\hline IVE Medical laboratory & . & very low \\
\hline $\begin{array}{l}\text { IVE Commerce and administration } \\
\text { SIVE Retail } \\
\text { SIVE Administration } \\
\text { IVE Retail } \\
\text { IVE Administration } \\
\text { IVE Commerce } \\
\text { IVE Secretarial }\end{array}$ & $\begin{array}{l}2 \\
3 \\
1 \\
2 \\
3 \\
1\end{array}$ & $\begin{array}{l}\text { average } \\
\text { average } \\
\text { low } \\
\text { average } \\
\text { average } \\
\text { low }\end{array}$ \\
\hline IVE Legal and fiscal & . & very low \\
\hline IVE Social and cultural & 4 & high \\
\hline $\begin{array}{l}\text { IVE Personal services } \\
\text { SIVE Community care } \\
\text { IVE Social services } \\
\text { IVE Community care } \\
\text { IVE Fashion and clothing } \\
\text { IVE Activities supervision }\end{array}$ & $\begin{array}{l}2 \\
1 \\
1 \\
.\end{array}$ & $\begin{array}{l}\text { very low } \\
\text { average } \\
\text { low } \\
\text { low } \\
\text { very low }\end{array}$ \\
\hline $\begin{array}{l}\text { IVE Hotel, catering and hairdressing } \\
\text { IVE Hotel and catering } \\
\text { IVE Building and food services maintenance } \\
\text { IVE Beauticians and hairdressing }\end{array}$ & . & $\begin{array}{l}\text { very low } \\
\text { very low } \\
\text { very low }\end{array}$ \\
\hline HVE & & \\
\hline $\begin{array}{l}\text { HVE Teacher training } \\
\text { HVE Primary school teacher } \\
\text { HVE Agricultural teacher } \\
\text { HVE Art and self-expression teacher } \\
\text { HVE Secondary school teacher }\end{array}$ & $\begin{array}{l}. \\
. \\
.\end{array}$ & $\begin{array}{l}- \\
- \\
-\end{array}$ \\
\hline HVE Interpreter and translator & . & - \\
\hline HVE Agriculture & . & - \\
\hline HVE Technical laboratory & . & - \\
\hline $\begin{array}{l}\text { HVE Technical } \\
\text { HVE Construction and civil engineering } \\
\text { HVE Mechanical engineering } \\
\text { HVE Electronic technology }\end{array}$ & . & - \\
\hline HVE Transport and harbour & . & - \\
\hline HVE Medical analysis & . & - \\
\hline $\begin{array}{l}\text { HVE Nursing and paramedical services } \\
\text { HVE Nursing } \\
\text { HVE Occupational and physiotherapy }\end{array}$ & $\begin{array}{l}1 \\
.\end{array}$ & $\begin{array}{l}\text { low } \\
-\end{array}$ \\
\hline
\end{tabular}


Table 3.7 (continued)

Percentage of working school-leavers who are from ethnic minorities per field of study, 1994

\begin{tabular}{lll}
\hline Type of education and field of study & $\%$ & qualitative charact. \\
\hline HVE Commerce and administration & & - \\
HVE Business administration & $\cdot$ & low \\
HVE Accounting & 1 & - \\
HVE Commercial information science & $\cdot$ & - \\
HVE Tourism & $\cdot$ & - \\
HVE Commerce & $\cdot$ & - \\
HVE Business administration technology & $\cdot$ & \\
HVE Legal and fiscal & & average \\
HVE Social and cultural & 2 & low \\
HVE Welfare and social work & 1 & - \\
HVE Personnel management & $\cdot$ & low \\
HVE Journalism & 1 &
\end{tabular}

Source: RUBS/HBO Monitor/ROA

- The percentage relates to the members of those ethnic minorities which fall under the 'Promotion of Balanced Employment Participation by Members of Ethnic Minorities Act' (Wet Bevordering Evenredige Arbeidsdeelname Allochtonen, WBEAA): i.e., those from Aruba, the Dutch Antilles, Ethiopia, Iraq, Iran, the former Yugoslavia, Morocco, Somalia, Surinam, Turkey and Vietnam. 
Table 3.8

Part-time work per type of education, average 1993-1994

\begin{tabular}{llll}
\hline Type of education & $\%$ & $\begin{array}{l}\text { qualitative } \\
\text { charact. }\end{array}$ & $\begin{array}{c}\text { trend } \\
1992-94\end{array}$ \\
\hline
\end{tabular}

\section{Primary Education}

Primary Education

25

average

\section{LGSE, PVE}

Lower General Secondary Education

PVE Agriculture

PVE Construction trades

PVE Utilities installation

PVE Mechanical trades

PVE Automobile trades

PVE Electrical trades

PVE Printing trades

PVE Food trades

PVE Textile and leather trades

PVE Transport and harbour

PVE Administration

PVE Commerce

PVE Community care, hotel and catering

PVE Security

$\begin{array}{rll}34 & \text { average } & \text { rising } \\ 12 & \text { low } & \text { constant } \\ 8 & \text { low } & - \\ . & \text { very low } & - \\ 6 & \text { low } & \text { rising strongly } \\ 8 & \text { low } & \text { falling strongly } \\ 6 & \text { low } & - \\ 16 & \text { low } & - \\ 51 & \text { average } & \text { rising strongly } \\ 38 & \text { very high } & - \\ 37 & \text { very low } & - \\ 62 & \text { high } & - \\ . & \text { high } & - \\ . & \text { very high } & \text { constant } \\ & \text { low } & -\end{array}$

\section{HGSE, IVE}

Higher General Secondary Education IVE Agriculture and the natural environment

IVE Technical Laboratory

IVE Construction technology

IVE Civil engineering

IVE Metalworking

IVE Precision engineering

IVE Mechanical engineering

IVE Automobile technology

IVE Electrical technology

IVE Printing technology

IVE Food technology

IVE Process technologies

IVE Textile and leather technology

IVE Transport and harbour

IVE Nursing and paramedical services

IVE Medical laboratory

IVE Retail

IVE Administration

IVE Tourism and recreation

IVE Commerce

IVE Secretarial

IVE Legal and fiscal

IVE Social and cultural

IVE Community care

IVE Hotel, catering and hairdressing

IVE Police, fire and defense

$\begin{array}{rll}31 & \text { average } & \text { rising } \\ 9 & \text { low } & - \\ 17 & \text { average } & \text { rising strongly } \\ 4 & \text { very low } & - \\ . & \text { low } & - \\ . & \text { very low } & - \\ . & \text { low } & - \\ 3 & \text { very low } & \text { rising strongly } \\ 6 & \text { low } & \text { rising strongly } \\ 4 & \text { very low } & \text { rising strongly } \\ . & \text { very low } & - \\ . & \text { very low } & - \\ & \text { low } & - \\ 39 & \text { high } & \text { rising } \\ 11 & \text { low } & \text { rising } \\ 60 & \text { very high } & \text { rising } \\ 44 & \text { high } & \text { rising strongly } \\ 23 & \text { average } & \text { rising } \\ 13 & \text { low } & \text { rising strongly } \\ 24 & \text { average } & - \\ 11 & \text { low } & \text { rising strongly } \\ 45 & \text { high } & \text { rising } \\ 17 & \text { average } & \text { rising strongly } \\ 44 & \text { high } & \text { constant } \\ 53 & \text { very high } & \text { constant } \\ 26 & \text { average } & - \\ 5 & \text { very low } & - \\ & & \end{array}$


Table 3.8 (continued)

Part-time work per type of education, average 1993-1994

\begin{tabular}{llll}
\hline Type of education & $\%$ & $\begin{array}{l}\text { qualitative } \\
\text { charact. }\end{array}$ & $\begin{array}{c}\text { trend } \\
1992-' 94\end{array}$ \\
\hline
\end{tabular}

HVE

HVE Teacher training

HVE Interpreter and translator

HVE Agriculture and environmental science

HVE Technical laboratory

HVE Construction and civil engineering

HVE Mechanical engineering

HVE Electronic and information technology

HVE Transport and harbour

HVE Medical laboratory

HVE Nursing and paramedical services

HVE Business administration

HVE Accounting

HVE Commercial information science

HVE Tourism and recreation

HVE Commerce

HVE Business administration technology

HVE Legal and fiscal

HVE Social and cultural

HVE Fine Arts

HVE Police, fire and defense

$\begin{array}{rll}35 & \text { average } & \text { constant } \\ 41 & \text { high } & \text { rising strongly } \\ 20 & \text { low } & - \\ . & \text { average } & \text { rising strongly } \\ . & \text { very low } & - \\ . & \text { very low } & - \\ . & \text { very low } & - \\ . & \text { low } & - \\ 45 & \text { high } & - \\ 47 & \text { high } & - \\ . & \text { low } & - \\ . & \text { low } & - \\ . & \text { low } & - \\ . & \text { average } & - \\ . & \text { very low } & - \\ . & \text { very low } & - \\ 12 & \text { low } & \text { rising strongly } \\ 42 & \text { high } & \text { rising } \\ 35 & \text { average } & - \\ . & \text { low } & -\end{array}$

UE

UE Arts

UE Theology

UE Agriculture and environmental science

UE Mathematics and natural sciences

UE Construction and civil engineering

UE Mechanical engineering

UE Electrical engineering and information technology

UE Veterinary and medical sciences and dentistry

UE Pharmacy

UE Economics, econometrics and business admin.

UE Management science

UE Information science

UE Law

UE Public administration

UE Social sciences

UE Fine Arts

$\begin{array}{ll}\text { high } & \text { rising strongly } \\ \text { average } & - \\ \text { average } & \text { rising strongly } \\ \text { low } & \text { falling } \\ \text { low } & - \\ \text { low } & - \\ \text { very low } & - \\ \text { average } & - \\ \text { low } & - \\ \text { low } & \text { rising } \\ \text { very low } & - \\ \text { low } & - \\ \text { average } & \text { rising } \\ \text { low } & - \\ \text { high } & - \\ \text { high } & -\end{array}$

Source: CBS/ROA 
Table 3.9

Part-time work among working school-leavers per field of study, 1994

Type of education and field of study $\%$ qualitative charact.

LGSE, PVE

Lower General Secondary Education

PVE Agriculture

PVE Technical

PVE Construction trades

PVE Utilities installation

PVE Mechanical trades

PVE Automobile trades

PVE Electrical trades

PVE Printing trades

PVE Food trades

PVE Textile and leather trades

PVE Commerce and administration

PVE Office administration

PVE Retailing

PVE Personal services

PVE Community care, hotel and catering

PVE Beauticians and hairdressing

HGSE, IVE

Higher General Secondary Education

Senior General Secondary Education

Pre-university Education

IVE Agriculture and the natural environment

SIVE Agricultural

IVE Agriculture-A

IVE Agriculture-B

IVE Technical Laboratory

SIVE Laboratory

IVE Chemical laboratory

IVE Technical

SIVE Metalworking

SIVE Automobile technology

SIVE Electrical technology

SIVE Food technology

IVE Construction technology

IVE Civil engineering

IVE Metalworking

IVE Mechanical engineering

IVE Automobile technology

IVE Electrical technology

IVE Process technologies

IVE Textile and leather technology

IVE Transport and harbour

IVE Nursing and paramedical services

IVE Nursing and home care

IVE Medical assistant
72

75

high

very high

high

very high

very high

very high

very high

high

very high

high

high

high

59

high

$94 \quad$ very high

high

high

67

high

average

32

average

low

average

high

average

very high

very low

very low

low

low

very low

average

low

average

low

average

average 
Table 3.9 (continued)

Part-time work among working school-leavers per field of study, 1994

\begin{tabular}{|c|c|c|}
\hline Type of education and field of study & $\%$ & qualitative charact. \\
\hline IVE Medical laboratory & 25 & average \\
\hline $\begin{array}{l}\text { IVE Commerce and administration } \\
\text { SIVE Retail } \\
\text { SIVE Administration } \\
\text { IVE Retail } \\
\text { IVE Administration } \\
\text { IVE Commerce } \\
\text { IVE Secretarial }\end{array}$ & $\begin{array}{l}65 \\
39 \\
22 \\
23 \\
22 \\
16\end{array}$ & $\begin{array}{l}\text { high } \\
\text { average } \\
\text { average } \\
\text { average } \\
\text { average } \\
\text { average }\end{array}$ \\
\hline IVE Legal and fiscal & 24 & average \\
\hline IVE Social and cultural & 39 & average \\
\hline $\begin{array}{l}\text { IVE Personal services } \\
\text { SIVE Community care } \\
\text { IVE Social services } \\
\text { IVE Community care } \\
\text { IVE Fashion and clothing } \\
\text { IVE Activities supervision }\end{array}$ & $\begin{array}{l}54 \\
54 \\
40 \\
47 \\
66\end{array}$ & $\begin{array}{l}\text { average } \\
\text { average } \\
\text { average } \\
\text { average } \\
\text { high }\end{array}$ \\
\hline $\begin{array}{l}\text { IVE Hotel, catering and hairdressing } \\
\text { IVE Hotel and catering } \\
\text { IVE Building and food services maintenance } \\
\text { IVE Beauticians and hairdressing }\end{array}$ & $\begin{array}{r}7 \\
58 \\
57\end{array}$ & $\begin{array}{l}\text { very low } \\
\text { high } \\
\text { high }\end{array}$ \\
\hline HVE & & \\
\hline $\begin{array}{l}\text { HVE Teacher training } \\
\text { HVE Primary school teacher } \\
\text { HVE Agricultural teacher } \\
\text { HVE Art and self-expression teacher } \\
\text { HVE Secondary school teacher }\end{array}$ & $\begin{array}{l}28 \\
25 \\
72 \\
42\end{array}$ & $\begin{array}{l}\text { average } \\
\text { average } \\
\text { high } \\
\text { average }\end{array}$ \\
\hline HVE Interpreter and translator & 21 & average \\
\hline HVE Agriculture & 12 & low \\
\hline HVE Technical laboratory & 8 & low \\
\hline $\begin{array}{l}\text { HVE Technical } \\
\text { HVE Construction and civil engineering } \\
\text { HVE Mechanical engineering } \\
\text { HVE Electronic technology }\end{array}$ & $\begin{array}{l}8 \\
7 \\
6\end{array}$ & $\begin{array}{l}\text { low } \\
\text { very low } \\
\text { very low }\end{array}$ \\
\hline HVE Transport and harbour & 3 & very low \\
\hline HVE Medical analysis & 8 & low \\
\hline $\begin{array}{l}\text { HVE Nursing and paramedical services } \\
\text { HVE Nursing } \\
\text { HVE Occupational and physiotherapy }\end{array}$ & $\begin{array}{l}47 \\
57\end{array}$ & $\begin{array}{l}\text { average } \\
\text { high }\end{array}$ \\
\hline
\end{tabular}


Table 3.9 (continued)

Part-time work among working school-leavers per field of study, 1994

\begin{tabular}{lcl}
\hline Type of education and field of study & $\%$ & qualitative charact. \\
\hline HVE Commerce and administration & & very low \\
HVE Business administration & 7 & very low \\
HVE Accounting & 3 & very low \\
HVE Commercial information science & 14 & low \\
HVE Tourism & 10 & low \\
HVE Commerce & 6 & very low \\
HVE Business administration technology & & low \\
HVE Legal and fiscal & 9 & \\
HVE Social and cultural & & high \\
HVE Welfare and social work & 55 & average \\
HVE Personnel management & 24 & average \\
HVE Journalism & 35 & average \\
HVE Fine Arts & 51 &
\end{tabular}

Source: RUBS/HBO Monitor/ROA 
Table 3.10

Self-employment per type of education, average 1993-1994

\begin{tabular}{llll}
\hline Type of education & $\%$ & qualitative & $\begin{array}{l}\text { trend } \\
\text { charact. }\end{array}$ \\
\hline
\end{tabular}

\section{Primary Education}

Primary Education

11

average

rising

LGSE, PVE

Lower General Secondary Education

PVE Agriculture

PVE Construction trades

PVE Utilities installation

PVE Mechanical trades

PVE Automobile trades

PVE Electrical trades

PVE Printing trades

PVE Food trades

PVE Textile and leather trades

PVE Transport and harbour

PVE Administration

PVE Commerce

PVE Community care, hotel and catering

PVE Security

low

very high

low

low

very low

-

average

low

low

low

average

HGSE, IVE

Higher General Secondary Education

IVE Agriculture and the natural environment

IVE Technical Laboratory

IVE Construction technology

IVE Civil engineering

IVE Metalworking

IVE Precision engineering

IVE Mechanical engineering

IVE Automobile technology

IVE Electrical technology

IVE Printing technology

IVE Food technology

IVE Process technologies

IVE Textile and leather technology

IVE Transport and harbour

IVE Nursing and paramedical services

IVE Medical laboratory

IVE Retail

IVE Administration

IVE Tourism and recreation

IVE Commerce

IVE Secretarial

IVE Legal and fiscal

IVE Social and cultural

IVE Community care

IVE Hotel, catering and hairdressing

IVE Police, fire and defense

$\begin{array}{ll}\begin{array}{ll}\text { average } \\ \text { very high }\end{array} & \text { rising strongly } \\ - & \text { constant } \\ \text { high } & \text { rising } \\ - & - \\ \text { very low } & \text { rising } \\ \text { high } & \text { rising strongly } \\ \text { very low } & - \\ \text { high } & \text { falling } \\ \text { very low } & \text { falling strongly } \\ \text { average } & - \\ \text { high } & \text { rising strongly } \\ \text { very low } & - \\ \text { average } & - \\ \text { average } & \text { rising strongly } \\ \text { very low } & - \\ \text { average } & - \\ \text { high } & - \\ \text { very low } & - \\ \text { - } & - \\ \text { average } & \text { rising strongly } \\ \text { very low } & \text { rising strongly } \\ \text { very low } & - \\ \text { very low } & - \\ \text { average } & \text { rising strongly } \\ \text { very high } & \text { falling } \\ \text { very low } & - \\ & \end{array}$


Table 3.10 (continued)

Self-employment per type of education, average 1993-1994

\begin{tabular}{llll}
\hline Type of education & $\%$ & $\begin{array}{l}\text { qualitative } \\
\text { charact. }\end{array}$ & $\begin{array}{l}\text { trend } \\
1992-' 94\end{array}$ \\
\hline
\end{tabular}

\section{HVE}

HVE Teacher training

HVE Interpreter and translator

HVE Agriculture and environmental science

HVE Technical laboratory

HVE Construction and civil engineering

HVE Mechanical engineering

HVE Electronic and information technology

HVE Transport and harbour

HVE Medical laboratory

HVE Nursing and paramedical services

HVE Business administration

HVE Accounting

HVE Commercial information science

HVE Tourism and recreation

HVE Commerce

HVE Business administration technology

HVE Legal and fiscal

HVE Social and cultural

HVE Fine Arts

HVE Police, fire and defense

UE

\section{UE Arts}

UE Theology

UE Agriculture and environmental science

UE Mathematics and natural sciences

UE Construction and civil engineering

UE Mechanical engineering

UE Electrical engineering and information technology

UE Veterinary and medical sciences and dentistry

UE Pharmacy

UE Economics, econometrics and business admin.

UE Management science

UE Information science

UE Law

UE Public administration

UE Social sciences

UE Fine Arts very low rising

- high low

high rising strongly

average falling strongly

average rising strongly

low -

low -

high $\quad$ falling

-

average -

$-$

average

low

very high rising

-

average -

- -

very low -

high -

- -

very high constant

- -

high

high -

high rising

-

low -

\section{Source: CBS/ROA}

- Including people working in the business or practice of their spouse or parents and freelancers etc. 
Table 3.11

Flexible work per type of education, average 1993-1994

\begin{tabular}{llll}
\hline Type of education & $\%$ & $\begin{array}{l}\text { qualitative } \\
\text { charact. }\end{array}$ & $\begin{array}{l}\text { trend } \\
1992-94\end{array}$ \\
\hline
\end{tabular}

Primary Education

Primary Education

LGSE, PVE

Lower General Secondary Education

PVE Agriculture

PVE Construction trades

PVE Utilities installation

PVE Mechanical trades

PVE Automobile trades

PVE Electrical trades

PVE Printing trades

PVE Food trades

PVE Textile and leather trades

PVE Transport and harbour

PVE Administration

PVE Commerce

PVE Community care, hotel and catering

PVE Security

$\begin{array}{ll}\text { high } & - \\ \text { low } & - \\ \text { low } & \text { rising strongly } \\ \text { average } & - \\ \text { low } & \text { rising strongly } \\ \text { average } & \text { rising strongly } \\ \text { average } & \text { falling strongly } \\ \text { low } & - \\ \text { average } & - \\ \text { high } & - \\ \text { low } & - \\ \text { average } & - \\ \text { high } & \text { rising } \\ \text { very high } & \text { constant } \\ \text { low } & -\end{array}$

HGSE, IVE

Higher General Secondary Education

IVE Agriculture and the natural environment

IVE Technical Laboratory

IVE Construction technology

IVE Civil engineering

IVE Metalworking

IVE Precision engineering

IVE Mechanical engineering

IVE Automobile technology

IVE Electrical technology

IVE Printing technology

IVE Food technology

IVE Process technologies

IVE Textile and leather technology

IVE Transport and harbour

IVE Nursing and paramedical services

IVE Medical laboratory

IVE Retail

IVE Administration

IVE Tourism and recreation

IVE Commerce

IVE Secretarial

IVE Legal and fiscal

IVE Social and cultural

IVE Community care

IVE Hotel, catering and hairdressing

IVE Police, fire and defense

$\begin{array}{ll}\text { very high } & - \\ \text { low } & - \\ \text { average } & - \\ \text { low } & \text { rising } \\ \text { low } & - \\ \text { low } & - \\ \text { low } & - \\ \text { low } & \text { rising strongly } \\ \text { low } & - \\ \text { low } & \text { rising strongly } \\ \text { low } & - \\ \text { low } & - \\ \text { low } & - \\ \text { average } & - \\ \text { low } & - \\ \text { high } & - \\ \text { low } & - \\ \text { average } & \text { rising } \\ \text { low } & - \\ \text { very high } & - \\ \text { average } & \text { rising } \\ \text { average } & - \\ \text { low } & - \\ \text { average } & - \\ \text { high } & - \\ \text { low } & - \\ \text { low } & -\end{array}$


Table 3.11 (continued)

Flexible work per type of education, average 1993-1994

\begin{tabular}{llll}
\hline Type of education & $\%$ & qualitative & $\begin{array}{c}\text { trend } \\
\text { charact. }\end{array}$
\end{tabular}

\section{HVE}

HVE Teacher training

HVE Interpreter and translator

HVE Agriculture and environmental science

HVE Technical laboratory

HVE Construction and civil engineering

HVE Mechanical engineering

HVE Electronic and information technology

HVE Transport and harbour

HVE Medical laboratory

HVE Nursing and paramedical services

HVE Business administration

HVE Accounting

HVE Commercial information science

HVE Tourism and recreation

HVE Commerce

HVE Business administration technology

HVE Legal and fiscal

HVE Social and cultural

HVE Fine Arts

HVE Police, fire and defense

UE

\section{UE Arts}

UE Theology

UE Agriculture and environmental science

UE Mathematics and natural sciences

UE Construction and civil engineering

UE Mechanical engineering

UE Electrical engineering and information technology

UE Veterinary and medical sciences and dentistry

UE Pharmacy

UE Economics, econometrics and business administration

7

very high

low

low

low

low

low

low

low

high

average

low

low

average

average

low

low

average

low

low rising strongly

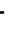$$
\text { - }
$$$$
\text { rising strongly }
$$$$
\text { - }
$$

$\begin{array}{cll}10 & \text { high } & \text { rising strongly } \\ . & \text { low } & - \\ . & \text { low } & - \\ . & \text { low } & - \\ . & \text { low } & - \\ . & \text { average } & - \\ . & \text { low } & - \\ . & \text { low } & - \\ . & \text { low } & - \\ 6 & \text { average } & \text { rising strongly } \\ . & \text { low } & - \\ . & \text { average } & - \\ . & \text { low } & - \\ . & \text { low } & - \\ 5 & \text { low } & - \\ . & \text { average } & -\end{array}$

UE Information science

UE Law

UE Public administration

UE Social sciences

UE Fine Arts

Source: CBS/ROA 
Table 3.12

Percentage of employees with permanent employment per type of education, average 1993-1994

\begin{tabular}{llll}
\hline Type of education & $\%$ & $\begin{array}{l}\text { qualitative } \\
\text { charact. }\end{array}$ & $\begin{array}{c}\text { trend } \\
1992-' 94\end{array}$ \\
\hline
\end{tabular}

Primary Education

Primary Education

91

low

constant

LGSE, PVE

Lower General Secondary Education

PVE Agriculture

PVE Construction trades

PVE Utilities installation

PVE Mechanical trades

PVE Automobile trades

PVE Electrical trades

PVE Printing trades

PVE Food trades

PVE Textile and leather trades

PVE Transport and harbour

PVE Administration

PVE Commerce

PVE Community care, hotel and catering

PVE Security

$\begin{array}{lll}88 & \text { very low } & - \\ 92 & \text { low } & - \\ 95 & \text { average } & \text { constant } \\ 94 & \text { average } & \text { constant } \\ 95 & \text { average } & \text { constant } \\ 94 & \text { average } & \text { constant } \\ 93 & \text { average } & - \\ 94 & \text { average } & - \\ 91 & \text { low } & - \\ 88 & \text { very low } & - \\ 95 & \text { average } & \text { rising } \\ 91 & \text { low } & - \\ 88 & \text { very low } & \text { constant } \\ 86 & \text { very low } & \text { constant } \\ 95 & \text { average } & \text { falling }\end{array}$

HGSE, IVE

Higher General Secondary Education

IVE Agriculture and the natural environment

IVE Technical Laboratory

IVE Construction technology

IVE Civil engineering

IVE Metalworking

IVE Precision engineering

IVE Mechanical engineering

IVE Automobile technology

IVE Electrical technology

IVE Printing technology

IVE Food technology

IVE Process technologies

IVE Textile and leather technology

IVE Transport and harbour

IVE Nursing and paramedical services

IVE Medical laboratory

IVE Retail

IVE Administration

IVE Tourism and recreation

IVE Commerce

IVE Secretarial

IVE Legal and fiscal

IVE Social and cultural

IVE Community care

IVE Hotel, catering and hairdressing

IVE Police, fire and defense

very low constant

low constant

low falling

high constant

average -

high constant

high falling

average constant

high -

average -

average falling

high -

very low $\quad$ constant

low -

average -

low constant

high constant

very low falling

low constant

low constant

very high -

low -

low constant

average rising

very high constant 
Table 3.12 (continued)

Percentage of employees with permanent employment per type of education, average 1993-1994

\begin{tabular}{llll}
\hline Type of education & $\%$ & $\begin{array}{l}\text { qualitative } \\
\text { charact. }\end{array}$ & $\begin{array}{c}\text { trend } \\
1992-' 94\end{array}$ \\
& & \\
\hline
\end{tabular}

\section{HVE}

HVE Teacher training

HVE Interpreter and translator

HVE Agriculture and environmental science

HVE Technical laboratory

HVE Construction and civil engineering

HVE Mechanical engineering

HVE Electronic and information technology

HVE Transport and harbour

HVE Medical laboratory

HVE Nursing and paramedical services

HVE Business administration

HVE Accounting

HVE Commercial information science

HVE Tourism and recreation

HVE Commerce

HVE Business administration technology

HVE Legal and fiscal

HVE Social and cultural

HVE Fine Arts

HVE Police, fire and defense

93
86
96
97
98
95
98
96
96
87
92
98
98
90
94
94
95
93
91
98

$\begin{array}{ll}\text { average } & - \\ \text { very low } & \text { rising } \\ \text { high } & - \\ \text { high } & \text { rising } \\ \text { high } & \text { constant } \\ \text { average } & \text { constant } \\ \text { very high } & - \\ \text { high } & \text { constant } \\ \text { high } & \text { constant } \\ \text { very low } & - \\ \text { low } & \text { falling } \\ \text { very high } & - \\ \text { very high } & \text { constant } \\ \text { low } & \text { constant } \\ \text { average } & - \\ \text { average } & \text { falling } \\ \text { average } & \text { failing } \\ \text { average } & \text { constant } \\ \text { low } & \text { constant } \\ \text { very high } & \text { constant }\end{array}$

UE

UE Arts

UE Theology

UE Agriculture and environmental science

UE Mathematics and natural sciences

UE Construction and civil engineering

UE Mechanical engineering

UE Electrical engineering and information technology

UE Veterinary and medical sciences and dentistry

UE Pharmacy

UE Economics, econometrics and business admin

UE Management science

UE Information science

UE Law

UE Public administration

UE Social sciences

UE Fine Arts

Source: CBS/ROA

$\begin{array}{ll}\text { very low } & - \\ \text { average } & - \\ \text { average } & - \\ \text { high } & - \\ \text { average } & - \\ \text { average } & - \\ \text { average } & \text { falling } \\ \text { average } & \text { constant } \\ \text { high } & \text { constant } \\ \text { average } & \text { constant } \\ \text { high } & - \\ \text { average } & \text { falling } \\ \text { average } & \text { constant } \\ \text { average } & - \\ \text { average } & - \\ \text { very low } & -\end{array}$


Table 3.13

Percentage of working school-leavers in permanent employment per field of study, 1994

\begin{tabular}{|c|c|c|}
\hline Type of education and field of study & $\%$ & qualitative charact. \\
\hline LGSE, PVE & & \\
\hline Lower General Secondary Education & 50 & average \\
\hline PVE Agriculture & 56 & average \\
\hline $\begin{array}{l}\text { PVE Technical } \\
\text { PVE Construction trades } \\
\text { PVE Utilities installation } \\
\text { PVE Mechanical trades } \\
\text { PVE Automobile trades } \\
\text { PVE Electrical trades } \\
\text { PVE Printing trades } \\
\text { PVE Food trades } \\
\text { PVE Textile and leather trades }\end{array}$ & $\begin{array}{r}64 \\
47 \\
57 \\
49 \\
. \\
37 \\
65\end{array}$ & $\begin{array}{l}\text { high } \\
\text { high } \\
\text { low } \\
\text { average } \\
\text { low } \\
\text { very high } \\
\text { very low } \\
\text { high }\end{array}$ \\
\hline $\begin{array}{l}\text { PVE Commerce and administration } \\
\text { PVE Office administration } \\
\text { PVE Retailing }\end{array}$ & $\begin{array}{l}42 \\
69\end{array}$ & $\begin{array}{l}\text { very low } \\
\text { high }\end{array}$ \\
\hline $\begin{array}{l}\text { PVE Personal services } \\
\text { PVE Community care, hotel and catering } \\
\text { PVE Beauticians and hairdressing }\end{array}$ & 65 & $\begin{array}{l}\text { high } \\
\text { very high }\end{array}$ \\
\hline HGSE, IVE & & \\
\hline $\begin{array}{l}\text { Higher General Secondary Education } \\
\text { Senior General Secondary Education } \\
\text { Pre-university Education }\end{array}$ & . & $\begin{array}{l}\text { very high } \\
\text { very low }\end{array}$ \\
\hline $\begin{array}{l}\text { IVE Agriculture and the natural environment } \\
\text { SIVE Agricultural } \\
\text { IVE Agriculture-A } \\
\text { IVE Agriculture-B }\end{array}$ & $\begin{array}{l}63 \\
77\end{array}$ & $\begin{array}{l}\text { average } \\
\text { average } \\
\text { very high }\end{array}$ \\
\hline $\begin{array}{l}\text { IVE Technical Laboratory } \\
\text { SIVE Laboratory } \\
\text { IVE Chemical laboratory }\end{array}$ & $\begin{array}{l}48 \\
43\end{array}$ & $\begin{array}{l}\text { low } \\
\text { low }\end{array}$ \\
\hline $\begin{array}{l}\text { IVE Technical } \\
\text { SIVE Metalworking } \\
\text { SIVE Automobile technology } \\
\text { SIVE Electrical technology } \\
\text { SIVE Food technology } \\
\text { IVE Construction technology } \\
\text { IVE Civil engineering } \\
\text { IVE Metalworking } \\
\text { IVE Mechanical engineering } \\
\text { IVE Automobile technology } \\
\text { IVE Electrical technology } \\
\text { IVE Process technologies } \\
\text { IVE Textile and leather technology }\end{array}$ & $\begin{array}{l}55 \\
48 \\
56 \\
33 \\
65 \\
61 \\
62 \\
64 \\
57 \\
75\end{array}$ & $\begin{array}{l}\text { average } \\
\text { low } \\
\text { average } \\
\text { very low } \\
\text { high } \\
\text { average } \\
\text { average } \\
\text { average } \\
\text { high } \\
\text { average } \\
\text { low } \\
\text { very high }\end{array}$ \\
\hline IVE Transport and harbour & 66 & high \\
\hline $\begin{array}{l}\text { IVE Nursing and paramedical services } \\
\text { IVE Nursing and home care } \\
\text { IVE Medical assistant }\end{array}$ & $\begin{array}{l}65 \\
77\end{array}$ & $\begin{array}{l}\text { high } \\
\text { very high }\end{array}$ \\
\hline
\end{tabular}


Table 3.13 (continued)

Percentage of working school-leavers in permanent employment per field of study, 1994

\begin{tabular}{|c|c|c|}
\hline Type of education and field of study & $\%$ & qualitative charact. \\
\hline IVE Medical laboratory & 65 & high \\
\hline $\begin{array}{l}\text { IVE Commerce and administration } \\
\text { SIVE Retail } \\
\text { SIVE Administration } \\
\text { IVE Retail } \\
\text { IVE Administration } \\
\text { IVE Commerce } \\
\text { IVE Secretarial }\end{array}$ & $\begin{array}{l}70 \\
51 \\
72 \\
61 \\
63 \\
60\end{array}$ & $\begin{array}{l}\text { high } \\
\text { average } \\
\text { very high } \\
\text { average } \\
\text { average } \\
\text { average }\end{array}$ \\
\hline IVE Legal and fiscal & 55 & average \\
\hline IVE Social and cultural & 39 & very low \\
\hline $\begin{array}{l}\text { IVE Personal services } \\
\text { SIVE Community care } \\
\text { IVE Social services } \\
\text { IVE Community care } \\
\text { IVE Fashion and clothing } \\
\text { IVE Activities supervision }\end{array}$ & $\begin{array}{l}58 \\
71 \\
72 \\
69 \\
71\end{array}$ & $\begin{array}{l}\text { average } \\
\text { high } \\
\text { very high } \\
\text { high } \\
\text { high }\end{array}$ \\
\hline $\begin{array}{l}\text { IVE Hotel, catering and hairdressing } \\
\text { IVE Hotel and catering } \\
\text { IVE Building and food services maintenance } \\
\text { IVE Beauticians and hairdressing }\end{array}$ & $\begin{array}{l}51 \\
48 \\
79\end{array}$ & $\begin{array}{l}\text { average } \\
\text { low } \\
\text { very high }\end{array}$ \\
\hline HVE & & \\
\hline $\begin{array}{l}\text { HVE Teacher training } \\
\text { HVE Primary school teacher } \\
\text { HVE Agricultural teacher } \\
\text { HVE Art and self-expression teacher } \\
\text { HVE Secondary school teacher }\end{array}$ & $\begin{array}{l}53 \\
43 \\
47 \\
41\end{array}$ & $\begin{array}{l}\text { average } \\
\text { low } \\
\text { low } \\
\text { very low }\end{array}$ \\
\hline HVE Interpreter and translator & 48 & low \\
\hline HVE Agriculture & 47 & low \\
\hline HVE Technical laboratory & 46 & very low \\
\hline $\begin{array}{l}\text { HVE Technical } \\
\text { HVE Construction and civil engineering } \\
\text { HVE Mechanical engineering } \\
\text { HVE Electronic technology }\end{array}$ & $\begin{array}{l}58 \\
45 \\
47\end{array}$ & $\begin{array}{l}\text { average } \\
\text { low } \\
\text { low }\end{array}$ \\
\hline HVE Transport and harbour & 93 & very high \\
\hline HVE Medical analysis & 55 & average \\
\hline $\begin{array}{l}\text { HVE Nursing and paramedical services } \\
\text { HVE Nursing } \\
\text { HVE Occupational and physiotherapy }\end{array}$ & $\begin{array}{l}70 \\
59\end{array}$ & $\begin{array}{l}\text { high } \\
\text { average }\end{array}$ \\
\hline
\end{tabular}


Table 3.13 (continued)

Percentage of working school-leavers in permanent employment per field of study, 1994

\begin{tabular}{|c|c|c|}
\hline Type of education and field of study & $\%$ & qualitative charact. \\
\hline $\begin{array}{l}\text { HVE Commerce and administration } \\
\text { HVE Business administration } \\
\text { HVE Accounting } \\
\text { HVE Commercial information science } \\
\text { HVE Tourism } \\
\text { HVE Commerce }\end{array}$ & $\begin{array}{l}53 \\
80 \\
59 \\
55 \\
55\end{array}$ & $\begin{array}{l}\text { average } \\
\text { very high } \\
\text { average } \\
\text { average } \\
\text { average }\end{array}$ \\
\hline HVE Business administration technology & 48 & low \\
\hline HVE Legal and fiscal & 56 & average \\
\hline $\begin{array}{l}\text { HVE Social and cultural } \\
\text { HVE Welfare and social work } \\
\text { HVE Personnel management } \\
\text { HVE Journalism }\end{array}$ & $\begin{array}{l}63 \\
46 \\
45\end{array}$ & $\begin{array}{l}\text { average } \\
\text { low } \\
\text { low }\end{array}$ \\
\hline HVE Fine Arts & 58 & average \\
\hline
\end{tabular}

Source: RUBS/HBO Monitor/ROA 
Table 3.14

Average gross monthly wage of working school-leavers per field of study, 1994

\begin{tabular}{lll}
\hline Type of education and field of study & $\begin{array}{l}\text { average gross qualitative charact. } \\
\text { monthly wage, } \\
\text { guilders }\end{array}$ \\
\hline
\end{tabular}

\section{LGSE, PVE}

Lower General Secondary Education

PVE Agriculture

PVE Technical

PVE Construction trades

PVE Utilities installation

PVE Mechanical trades

PVE Automobile trades

PVE Electrical trades

PVE Printing trades

PVE Food trades

PVE Textile and leather trades

PVE Commerce and administration

PVE Office administration

PVE Retailing

PVE Personal services

PVE Community care, hotel and catering $\quad 1,075$

PVE Beauticians and hairdressing

HGSE, IVE

Higher General Secondary Education Senior General Secondary Education

Pre-university Education

IVE Agriculture and the natural environment

SIVE Agricultural

IVE Agriculture-A

IVE Agriculture-B

IVE Technical Laboratory

SIVE Laboratory

IVE Chemical laboratory

IVE Technical

SIVE Metalworking

SIVE Automobile technology

SIVE Electrical technology

SIVE Food technology

IVE Construction technology 2,393

IVE Civil engineering

IVE Mechanical engineering $\quad 2,263$

$\begin{array}{ll}\text { IVE Automobile technology } & 2,314 \\ \text { IVE Electrical technology } & 2,290\end{array}$

IVE Process technologies

IVE Textile and leather technology

IVE Transport and harbour

IVE Nursing and paramedical services

IVE Nursing and home care

IVE Medical assistant
1,189

1,151

1,000

2,485

2,450

2,509

2,270

average for LGSE/PVE

average for LGSE/PVE

average for LGSE/PVE average for LGSE/PVE average for LGSE/PVE average for LGSE/PVE average for LGSE/PVE high for LGSE/PVE average for LGSE/PVE average for LGSE/PVE

average for LGSE/PVE average for LGSE/PVE

average for LGSE/PVE average for LGSE/PVE

low for HGSE/IVE

average for HGSE/IVE

average for HGSE/IVE high for HGSE/IVE average for HGSE/IVE

high for HGSE/IVE

high for HGSE/IVE

average for HGSE/IVE average for HGSE/IVE average for HGSE/IVE average for HGSE/IVE average for HGSE/IVE high for HGSE/IVE high for HGSE/IVE average for HGSE/IVE average for HGSE/IVE average for HGSE/IVE very high for HGSE/IVE average for HGSE/IVE

average for HGSE/IVE 
Table 3.14 (continued)

Average gross monthly wage of working school-leavers per field of study, 1994

\begin{tabular}{|c|c|c|}
\hline Type of education and field of study & $\begin{array}{l}\text { average gross } \\
\text { monthly wage, } \\
\text { guilders }\end{array}$ & qualitative charact. \\
\hline IVE Medical laboratory & 2,674 & high for HGSE/IVE \\
\hline $\begin{array}{l}\text { IVE Commerce and administration } \\
\text { SIVE Retail } \\
\text { SIVE Administration } \\
\text { IVE Retail } \\
\text { IVE Administration } \\
\text { IVE Commerce } \\
\text { IVE Secretarial }\end{array}$ & $\begin{array}{l}1,888 \\
1,610 \\
2,033 \\
1,923 \\
1,938 \\
1,852\end{array}$ & $\begin{array}{l}\text { average for HGSE/IVE } \\
\text { average for HGSE/IVE } \\
\text { average for HGSE/IVE } \\
\text { average for HGSE/IVE } \\
\text { average for HGSE/IVE } \\
\text { average for HGSE/IVE }\end{array}$ \\
\hline IVE Legal and fiscal & 2,171 & average for HGSE/IVE \\
\hline IVE Social and cultural & 2,234 & average for HGSE/IVE \\
\hline $\begin{array}{l}\text { IVE Personal services } \\
\text { SIVE Community care } \\
\text { IVE Social services } \\
\text { IVE Community care } \\
\text { IVE Fashion and clothing } \\
\text { IVE Activities supervision }\end{array}$ & $\begin{array}{l}1,683 \\
2,070 \\
2,099 \\
1,823 \\
2,617\end{array}$ & $\begin{array}{l}\text { average for HGSE/IVE } \\
\text { average for HGSE/IVE } \\
\text { average for HGSE/IVE } \\
\text { average for HGSE/IVE } \\
\text { high for HGSE/IVE }\end{array}$ \\
\hline $\begin{array}{l}\text { IVE Hotel, catering and hairdressing } \\
\text { IVE Hotel and catering } \\
\text { IVE Building and food services maintenance } \\
\text { IVE Beauticians and hairdressing }\end{array}$ & $\begin{array}{l}2,732 \\
2,066 \\
1,749\end{array}$ & $\begin{array}{l}\text { high for HGSE/IVE } \\
\text { average for HGSE/VE } \\
\text { average for HGSE/IVE }\end{array}$ \\
\hline HVE & & \\
\hline $\begin{array}{l}\text { HVE Teacher training } \\
\text { HVE Primary school teacher } \\
\text { HVE Agricultural teacher } \\
\text { HVE Art and self-expression teacher } \\
\text { HVE Secondary school teacher }\end{array}$ & $\begin{array}{l}3,170 \\
3,293 \\
3,212 \\
2,918\end{array}$ & $\begin{array}{l}\text { average for } \mathrm{HVE} \\
\text { average for } \mathrm{HVE} \\
\text { average for } \mathrm{HVE} \\
\text { average for } \mathrm{HVE}\end{array}$ \\
\hline HVE Interpreter and translator & 3,247 & average for HVE \\
\hline HVE Agriculture & 3,086 & average for HVE \\
\hline HVE Technical laboratory & 3,106 & average for HVE \\
\hline $\begin{array}{l}\text { HVE Technical } \\
\text { HVE Construction and civil engineering } \\
\text { HVE Mechanical engineering } \\
\text { HVE Electronic technology }\end{array}$ & $\begin{array}{l}3,333 \\
3,237 \\
3,273\end{array}$ & $\begin{array}{l}\text { average for HVE } \\
\text { average for HVE } \\
\text { average for HVE }\end{array}$ \\
\hline HVE Transport and harbour & 2,769 & average for HVE \\
\hline HVE Medical analysis & 2,984 & average for HVE \\
\hline $\begin{array}{l}\text { HVE Nursing and paramedical services } \\
\text { HVE Nursing } \\
\text { HVE Occupational and physiotherapy }\end{array}$ & $\begin{array}{l}3,405 \\
4,078\end{array}$ & $\begin{array}{l}\text { average for HVE } \\
\text { high for HVE }\end{array}$ \\
\hline
\end{tabular}


Table 3.14 (continued)

Average gross monthly wage of working school-leavers per field of study, 1994

\begin{tabular}{lll}
\hline Type of education and field of study & $\begin{array}{l}\text { average gross } \\
\text { monthly wage, } \\
\text { guilders }\end{array}$ & qualitative charact. \\
\hline HVE Commerce and administration & & \\
HVE Business administration & 3,100 & average for HVE \\
HVE Accounting & 3,267 & average for HVE \\
HVE Commercial information science & 3,253 & average for HVE \\
low for HVE & average for HVE \\
HVE Commerce & 2,576 & average for HVE \\
HVE Business administration technology & 3,115 & average for HVE \\
HVE Legal and fiscal & 3,222 & \\
HVE Social and cultural & 3,076 & average for HVE \\
HVE Welfare and social work & & average for HVE \\
HVE Personnel management & 3,227 & average for HVE \\
HVE Journalism & 3,487 & average for HVE \\
HVE Fine Arts & 3,415 & 3,383
\end{tabular}

Source: RUBS/HBO Monitor/ROA 
Table 3.15

Most important occupational classes per type of education, average 1993-1994

\begin{tabular}{|c|c|c|}
\hline Type of education & $\%$ & $\begin{array}{l}\text { trend } \\
1992-' 94\end{array}$ \\
\hline \multicolumn{3}{|l|}{ Primary Education } \\
\hline $\begin{array}{l}\text { Primary Education } \\
\text { Porters, cleaners and domestics } \\
\text { Drivers and conductors } \\
\text { Freight handlers and packers } \\
\text { Sales assistants }\end{array}$ & $\begin{array}{l}9 \\
8 \\
7 \\
5\end{array}$ & $\begin{array}{l}- \\
\text { rising } \\
- \\
-\end{array}$ \\
\hline \multicolumn{3}{|l|}{ LGSE, PVE } \\
\hline $\begin{array}{l}\text { Lower General Secondary Education } \\
\text { Book-keepers and bank employees } \\
\text { Purchasing and sales clerks } \\
\text { Sales assistants }\end{array}$ & $\begin{array}{r}12 \\
11 \\
9\end{array}$ & $\begin{array}{l}- \\
\text { falling }\end{array}$ \\
\hline $\begin{array}{l}\text { PVE Agriculture } \\
\text { Farmers } \\
\text { Agricultural workers } \\
\text { Drivers and conductors }\end{array}$ & $\begin{array}{r}37 \\
19 \\
5\end{array}$ & $\begin{array}{l}- \\
-\end{array}$ \\
\hline $\begin{array}{l}\text { PVE Construction trades } \\
\text { Carpenters and woodworkers } \\
\text { Bricklayers and plasterers } \\
\text { Painters } \\
\text { Road construction workers and pipelayers } \\
\text { Drivers and conductors }\end{array}$ & $\begin{array}{r}28 \\
10 \\
5 \\
5 \\
5\end{array}$ & $\begin{array}{l}\text { rising } \\
\text { falling strongly } \\
\text { rising } \\
\text { falling strongly }\end{array}$ \\
\hline $\begin{array}{l}\text { PVE Utilities installation } \\
\text { Plumbers }\end{array}$ & 38 & - \\
\hline $\begin{array}{l}\text { PVE Mechanical trades } \\
\text { Welders and engineering workers } \\
\text { Lathe operators and metal workers } \\
\text { Drivers and conductors } \\
\text { Machinery mechanics and instrument makers } \\
\text { Managers and supervisors in manufacturing }\end{array}$ & $\begin{array}{r}15 \\
9 \\
7 \\
6 \\
6\end{array}$ & $\begin{array}{l}\text { rising } \\
- \\
- \\
- \\
\text { rising }\end{array}$ \\
\hline $\begin{array}{l}\text { PVE Automobile trades } \\
\text { Automobile mechanics } \\
\text { Drivers and conductors }\end{array}$ & $\begin{array}{l}21 \\
16\end{array}$ & rising strongly \\
\hline $\begin{array}{l}\text { PVE Electrical trades } \\
\text { Electricians and telecommunication servicemen }\end{array}$ & 26 & falling \\
\hline $\begin{array}{l}\text { PVE Printing trades } \\
\text { Printing industry production workers }\end{array}$ & 44 & falling \\
\hline $\begin{array}{l}\text { PVE Food trades } \\
\text { Bakers and bakery personnel } \\
\text { Cooks, waiters and kitchen workers }\end{array}$ & $\begin{array}{l}16 \\
13\end{array}$ & falling strongly \\
\hline $\begin{array}{l}\text { PVE Textile and leather trades } \\
\text { Sales assistants }\end{array}$ & 15 & - \\
\hline $\begin{array}{l}\text { PVE Transport and harbour } \\
\text { Drivers and conductors }\end{array}$ & 59 & - \\
\hline
\end{tabular}


Table 3.15 (continued)

Most important occupational classes per type of education, average 1993-1994

\begin{tabular}{lll}
\hline Type of education & $\%$ & trend \\
& $1992-94$ \\
\hline
\end{tabular}

PVE Administration

Book-keepers and bank employees

Purchasing and sales clerks

Sales assistants

23

14

10

PVE Commerce

Sales assistants

Book-keepers and bank employees

$\begin{aligned} 26 & - \\ 9 & \text { falling } \\ & \\ 15 & \text { rising } \\ 13 & - \\ 11 & - \\ 7 & \text { falling strongly } \\ 7 & -\end{aligned}$

63

rising

Police, fire and security officers

HGSE, IVE

Higher General Secondary Education

Purchasing and sales clerks

Book-keepers and bank employees

Sales assistants

Secretaries and typists

falling

rising

IVE Agriculture and the natural environment

Farmers

Agricultural workers

rising

IVE Technical Laboratory

Technical analysts and laboratory assistants

rising strongly

IVE Construction technology

Carpenters and woodworkers

Managers and supervisors in manufacturing

Painters

Plumbers

Construction supervisors

Bricklayers and plasterers

constant

IVE Civil engineering

Managers and supervisors in manufacturing

Construction supervisors

Technical draughtsmen

IVE Metalworking

Lathe operators and metal workers

Welders and engineering workers

Machinery mechanics and instrument makers

Managers and supervisors in manufacturing

rising strongly

falling

IVE Precision engineering 
Table 3.15 (continued)

Most important occupational classes per type of education, average 1993-1994

\begin{tabular}{|c|c|c|}
\hline Type of education & $\%$ & $\begin{array}{l}\text { trend } \\
1992-' 94\end{array}$ \\
\hline \multicolumn{3}{|l|}{ IVE Mechanical engineering } \\
\hline Managers and supervisors in manufacturing & 14 & falling \\
\hline Machinery mechanics and instrument makers & 13 & falling \\
\hline Lathe operators and metal workers & 7 & constant \\
\hline Technical draughtsmen & 6 & - \\
\hline Construction machine operators construction and industry & 6 & - \\
\hline \multicolumn{3}{|l|}{ IVE Automobile technology } \\
\hline Automobile mechanics & 30 & - \\
\hline Managers and supervisors in manufacturing & 12 & falling \\
\hline Drivers and conductors & 8 & - \\
\hline Machinery mechanics and instrument makers & 6 & - \\
\hline Lathe operators and metal workers & 6 & - \\
\hline \multicolumn{3}{|l|}{ IVE Electrical technology } \\
\hline Electricians and telecommunication servicemen & 34 & constant \\
\hline Managers and supervisors in manufacturing & 11 & - \\
\hline Machinery mechanics and instrument makers & 6 & rising strongly \\
\hline \multicolumn{3}{|l|}{ IVE Printing technology } \\
\hline Printing industry production workers & 42 & falling \\
\hline Managers and supervisors in manufacturing & 18 & \\
\hline Photographers and designers & 12 & falling \\
\hline \multicolumn{3}{|l|}{ IVE Food technology } \\
\hline Bakers and bakery personnel & 25 & - \\
\hline Food and beverage processors & 20 & rising \\
\hline Shopkeepers, retail and wholesale staff & 13 & rising strongly \\
\hline Managers and supervisors in manufacturing & 8 & falling strongly \\
\hline \multicolumn{3}{|l|}{ IVE Process technologies } \\
\hline Chemical process workers & 36 & - \\
\hline Managers and supervisors in manufacturing & 15 & - \\
\hline \multicolumn{3}{|l|}{ IVE Textile and leather technology } \\
\hline Sales assistants & 18 & - \\
\hline Clothing production workers and sailmakers & 10 & - \\
\hline Upholsterers, shoemakers and leatherworkers & 8 & - \\
\hline \multicolumn{3}{|l|}{ IVE Transport and harbour } \\
\hline Drivers and conductors & 23 & - \\
\hline Purchasing and sales clerks & 10 & - \\
\hline Managers and supervisors in manufacturing & 9 & falling \\
\hline Ship's officers and marine inspectors & 8 & rising strongly \\
\hline Book-keepers and bank employees & 6 & - \\
\hline \multicolumn{3}{|l|}{ IVE Nursing and paramedical services } \\
\hline Nursing staff & 35 & constant \\
\hline Student nurses and home nursing personnel & 29 & constant \\
\hline Doctors', dentists' and vetinary assistants & 6 & - \\
\hline \multicolumn{3}{|l|}{ IVE Medical laboratory } \\
\hline Pharmacy assistants and opticians & 51 & - \\
\hline Medical and biological laboratory analysts & 10 & rising strongly \\
\hline
\end{tabular}


Table 3.15 (continued)

Most important occupational classes per type of education, average 1993-1994

\begin{tabular}{lll}
\hline Type of education & trend \\
$1992-94$
\end{tabular}

IVE Retail

Shopkeepers, retail and wholesale staff

Sales assistants

Purchasing and sales clerks

Book-keepers and bank employees

Managers and supervisors in manufacturing

1992-'94

IVE Administration

Book-keepers and bank employees

Purchasing and sales clerks

Senior finance and sales managers

52

13
6

rising

constant

constant

rising strongly

IVE Tourism and recreation

Telephonists, receptionists and pollsters

Book-keepers and bank employees

IVE Commerce

Commercial representatives, buyers and branch managers 22

Purchasing and sales clerks

Book-keepers and bank employees

constant

falling

falling strongly

IVE Secretarial

Secretaries and typists

Purchasing and sales clerks

Book-keepers and bank employees

Telephonists, receptionists and pollsters

VE Legal and fiscal

Book-keepers and bank employees

Purchasing and sales clerks

IVE Social and cultural

Community workers and probation officers

Geriatric help and kindergarten staff

Student nurses and home nursing personnel

Purchasing and sales clerks

Library and archive assistants

IVE Community care

Geriatric help and kindergarten staff

Student nurses and home nursing personnel

Cooks, waiters and kitchen workers

Hairdressers and beauticians

Sales assistants

rising

IVE Hotel, catering and hairdressing

Hotel and catering owners and supervisors

Hairdressers and beauticians

Cooks, waiters and kitchen workers

Sales assistants

rising

rising strongly

falling

rising

rising

rising

rising

falling strongly

IVE Police, fire and defense

Police, fire and security officers

Military professionals

$\begin{aligned} 23 & \text { rising } \\ 13 & \text { rising } \\ 11 & - \\ 8 & \text { rising } \\ 5 & \text { falling strongly } \\ & \\ 21 & \text { rising } \\ 20 & \text { falling strongly } \\ 15 & \text { rising strongly } \\ 6 & -\end{aligned}$


Table 3.15 (continued)

Most important occupational classes per type of education, average 1993-1994

\begin{tabular}{|c|c|c|}
\hline Type of education & $\%$ & $\begin{array}{l}\text { trend } \\
1992-' 94\end{array}$ \\
\hline HVE & & \\
\hline $\begin{array}{l}\text { HVE Teacher training } \\
\text { Primary and special education teachers } \\
\text { Secondary and tertiary education teachers } \\
\text { School principals and other higher educational professions }\end{array}$ & $\begin{array}{r}34 \\
28 \\
9\end{array}$ & $\begin{array}{l}\text { constant } \\
\text { constant } \\
\text { rising }\end{array}$ \\
\hline $\begin{array}{l}\text { HVE Interpreter and translator } \\
-\end{array}$ & - & - \\
\hline $\begin{array}{l}\text { HVE Agriculture and environmental science } \\
\text { - }\end{array}$ & - & - \\
\hline $\begin{array}{l}\text { HVE Technical laboratory } \\
\text { Technical analysts and laboratory assistants } \\
\text { Medical and biological laboratory analysts } \\
\text { Scientific researchers, technicians and statisticians }\end{array}$ & $\begin{array}{l}31 \\
15 \\
10\end{array}$ & falling \\
\hline $\begin{array}{l}\text { HVE Construction and civil engineering } \\
\text { Architects and construction engineers } \\
\text { Managers and supervisors in manufacturing } \\
\text { Construction supervisors } \\
\text { Technical draughtsmen }\end{array}$ & $\begin{array}{r}29 \\
20 \\
13 \\
9\end{array}$ & $\begin{array}{l}- \\
\text { rising strongly }\end{array}$ \\
\hline $\begin{array}{l}\text { HVE Mechanical engineering } \\
\text { Managers and supervisors in manufacturing } \\
\text { Higher mechanical engineers }\end{array}$ & $\begin{array}{r}28 \\
9\end{array}$ & falling strongly \\
\hline $\begin{array}{l}\text { HVE Electronic and information technology } \\
\text { Programmers and system analysts } \\
\text { Higher electrical engineers } \\
\text { Managers and supervisors in manufacturing }\end{array}$ & $\begin{array}{l}31 \\
17 \\
13\end{array}$ & $\begin{array}{l}- \\
-\end{array}$ \\
\hline $\begin{array}{l}\text { HVE Transport and harbour } \\
\text { Managers and supervisors in manufacturing }\end{array}$ & 17 & falling strongly \\
\hline $\begin{array}{l}\text { Pilots and transport and freight supervisors } \\
\text { Ship's officers and marine inspectors }\end{array}$ & $\begin{array}{l}15 \\
10\end{array}$ & - \\
\hline $\begin{array}{l}\text { HVE Medical laboratory } \\
\text { Medical and biological laboratory analysts }\end{array}$ & 60 & constant \\
\hline $\begin{array}{l}\text { HVE Nursing and paramedical services } \\
\text { Nursing staff } \\
\text { Physiotherapists and occupational therapists } \\
\text { Paramedics and related functions }\end{array}$ & $\begin{array}{l}30 \\
28 \\
14\end{array}$ & $\begin{array}{l}\text { falling } \\
\text { rising strongly } \\
-\end{array}$ \\
\hline $\begin{array}{l}\text { HVE Business administration } \\
\text { Book-keepers and bank employees } \\
\text { Managers and supervisors in manufacturing }\end{array}$ & $\begin{array}{l}32 \\
13\end{array}$ & - \\
\hline $\begin{array}{l}\text { HVE Accounting } \\
\text { Accountants and economists } \\
\text { Book-keepers and bank employees } \\
\text { Senior finance and sales managers }\end{array}$ & $\begin{array}{l}32 \\
29 \\
15\end{array}$ & $\begin{array}{l}- \\
-\end{array}$ \\
\hline
\end{tabular}


Table 3.15 (continued)

Most important occupational classes per type of education, average 1993-1994

Type of education $\%$ trend

HVE Commercial information science Programmers and system analysts

falling

HVE Tourism and recreation

HVE Commerce

Commercial representatives, buyers and branch managers 20

HVE Business administration technology

Managers and supervisors in manufacturing

Secretaries and typists

HVE Legal and fiscal

Purchasing and sales clerks

Civil servants (public administration)

Accountants and economists

14

10

rising strongly

HVE Social and cultural

Community workers and probation officers

Personnel officers and vocational advisors

Librarians and archivists

Senior finance and sales managers

24

10

7

HVE Fine Arts

Visual and performing artists

Photographers and designers

Secondary and tertiary education teachers

35

20

HVE Police, fire and defense

Military professionals

UE

UE Arts

Secondary and tertiary education teachers Journalists and announcers

33

63

Pastoral vocations

UE Agriculture and environmental science

UE Mathematics and natural sciences

Scientific researchers, technicians and statisticians

Secondary and tertiary education teachers

Programmers and system analysts

Managers and supervisors in manufacturing

Architects and construction engineers falling strongly

constant

rising strongly

rising

falling

falling

constant

falling strongly

falling strongly

rising strongly

UE Mechanical engineering 
Table 3.15 (continued)

Most important occupational classes per type of education, average 1993-1994

\begin{tabular}{|c|c|c|}
\hline Type of education & $\%$ & $\begin{array}{l}\text { trend } \\
1992-' 94\end{array}$ \\
\hline \multicolumn{3}{|l|}{ UE Electrical engineering and information technology } \\
\hline Programmers and system analysts & 27 & - \\
\hline Higher electrical engineers & 21 & falling strongly \\
\hline \multicolumn{3}{|l|}{ UE Veterinary and medical sciences and dentistry } \\
\hline Physicians, medical specialists and pharmacists & 65 & - \\
\hline Dentists and dental specialists & 10 & falling \\
\hline Vetinary surgeons & 6 & falling \\
\hline \multicolumn{3}{|l|}{ UE Pharmacy } \\
\hline Physicians, medical specialists and pharmacists & 53 & falling strongly \\
\hline \multicolumn{3}{|l|}{ UE Economics, econometrics and business administration } \\
\hline Accountants and economists & 32 & - \\
\hline Managers and supervisors in manufacturing & 14 & falling \\
\hline Book-keepers and bank employees & 11 & - \\
\hline Secondary and tertiary education teachers & 8 & rising \\
\hline Senior finance and sales managers & 7 & falling strongly \\
\hline \multicolumn{3}{|l|}{ UE Management science } \\
\hline Managers and supervisors in manufacturing & 36 & falling \\
\hline \multicolumn{3}{|l|}{ UE Information science } \\
\hline- & - & - \\
\hline \multicolumn{3}{|l|}{ UE Law } \\
\hline Legal professionals & 47 & - \\
\hline Purchasing and sales clerks & 10 & rising strongly \\
\hline Managers and supervisors in manufacturing & 5 & falling strongly \\
\hline Civil servants (public administration) & 5 & - \\
\hline \multicolumn{3}{|l|}{ UE Public administration } \\
\hline Accountants and economists & 31 & - \\
\hline \multicolumn{3}{|l|}{ UE Social sciences } \\
\hline Social scientists & 14 & falling \\
\hline Secondary and tertiary education teachers & 13 & - \\
\hline Community workers and probation officers & 10 & falling strongly \\
\hline Managers and supervisors in manufacturing & 10 & - \\
\hline School principals and other higher educational professions & 8 & rising \\
\hline Purchasing and sales clerks & 7 & rising \\
\hline \multicolumn{3}{|l|}{ UE Fine Arts } \\
\hline Secondary and tertiary education teachers & 40 & constant \\
\hline
\end{tabular}

Source: CBS/ROA 
Table 3.16

Opportunities to switch to other occupational groups at a matching or higher function level per type of education, average 1993-1994

\begin{tabular}{lll}
\hline Type of education & $\begin{array}{l}\text { Gini-Hirschman } \\
\text { dispersion index }\end{array}$ & $\begin{array}{l}\text { qualitative } \\
\text { charact. }\end{array}$ \\
\hline
\end{tabular}

\section{Primary Education}

Primary Education

very high

LGSE, PVE

Lower General Secondary Education

PVE Agriculture

PVE Construction trades

PVE Utilities installation

PVE Mechanical trades

PVE Automobile trades

PVE Electrical trades

PVE Printing trades

PVE Food trades

PVE Textile and leather trades

PVE Transport and harbour

PVE Administration

PVE Commerce

PVE Community care, hotel and catering

PVE Security

$\begin{array}{ll}0.95 & \text { high } \\ 0.73 & \text { low } \\ 0.86 & \text { average } \\ 0.63 & \text { very low } \\ 0.97 & \text { very high } \\ 0.85 & \text { average } \\ 0.93 & \text { high } \\ 0.88 & \text { average } \\ 0.87 & \text { average } \\ 0.95 & \text { high } \\ 0.96 & \text { very high } \\ 0.88 & \text { average } \\ 0.95 & \text { high } \\ 0.94 & \text { high } \\ 0.91 & \text { average }\end{array}$

\section{HGSE, IVE}

Higher General Secondary Education

$\begin{array}{ll}0.95 & \text { high } \\ 0.75 & \text { low } \\ 0.65 & \text { low } \\ 0.89 & \text { average } \\ 0.89 & \text { average } \\ 0.93 & \text { high } \\ 0.93 & \text { high } \\ 0.95 & \text { high } \\ 0.80 & \text { low } \\ 0.93 & \text { high } \\ 0.92 & \text { high } \\ 0.90 & \text { average } \\ 0.84 & \text { average } \\ 0.95 & \text { high } \\ 0.93 & \text { high } \\ 0.74 & \text { low } \\ 0.73 & \text { low } \\ 0.96 & \text { very high } \\ 0.71 & \text { low } \\ 0.79 & \text { low } \\ 0.92 & \text { high } \\ 0.64 & \text { very low } \\ 0.84 & \text { average } \\ 0.89 & \text { average } \\ 0.86 & \text { average } \\ 0.86 & \text { average } \\ 0.85 & \text { average }\end{array}$

IVE Agriculture and the natural environment

IVE Technical Laboratory

IVE Construction technology

IVE Civil engineering

IVE Metalworking

IVE Precision engineering

IVE Mechanical engineering

IVE Automobile technology

IVE Electrical technology

IVE Printing technology

IVE Food technology

IVE Process technologies

IVE Textile and leather technology

IVE Transport and harbour

IVE Nursing and paramedical services

IVE Medical laboratory

IVE Retail

IVE Administration

IVE Tourism and recreation

IVE Commerce

IVE Secretarial

IVE Legal and fiscal

IVE Social and cultural

IVE Community care

IVE Hotel, catering and hairdressing

IVE Police, fire and defense 
Table 3.16 (continued)

Opportunities to switch to other occupational groups at a matching or higher function level per type of education, average 1993-1994

\begin{tabular}{lll}
\hline Type of education & $\begin{array}{l}\text { Gini-Hirschman } \\
\text { dispersion index }\end{array}$ & $\begin{array}{l}\text { qualitative } \\
\text { charact. }\end{array}$ \\
\hline
\end{tabular}

\section{HVE}

HVE Teacher training

HVE Interpreter and translator

HVE Agriculture and environmental science

HVE Technical laboratory

HVE Construction and civil engineering

HVE Mechanical engineering

HVE Electronic and information technology

HVE Transport and harbour

HVE Medical laboratory

HVE Nursing and

HVE Business administration

HVE Accounting

HVE Commercial information science

HVE Tourism and recreation

HVE Commerce

HVE Business administration technology

HVE Legal and fiscal

HVE Social and cultural

HVE Fine Arts

HVE Police, fire and defense

$\begin{array}{ll}0.80 & \text { low } \\ 0.86 & \text { average } \\ 0.94 & \text { high } \\ 0.82 & \text { average } \\ 0.88 & \text { average } \\ 0.95 & \text { high } \\ 0.87 & \text { average } \\ 0.93 & \text { high } \\ 0.72 & \text { low } \\ 0.77 & \text { low } \\ 0.93 & \text { high } \\ 0.74 & \text { low } \\ 0.59 & \text { very low } \\ 0.78 & \text { low } \\ 0.90 & \text { average } \\ 0.92 & \text { high } \\ 0.90 & \text { average } \\ 0.86 & \text { average } \\ 0.87 & \text { average } \\ 0.86 & \text { average }\end{array}$

UE

UE Arts

0.78 low

UE Theology

0.57

UE Agriculture and environmental science

UE Mathematics and natural sciences

0.95

UE Construction and civil engineering

0.91

UE Mechanical engineering

UE Electrical engineering and information technology

0.81

0.90

UE Veterinary and medical sciences and dentistry

UE Pharmacy

0.86

0.51

0.60

UE Economics, econometrics and business administration

0.87

UE Management science

0.88

UE Information science

0.64

UE Law

UE Public administration

0.81

0.82

UE Social sciences

0.91

UE Fine Arts

0.75

low
very low
high
average
low
average
average
very low
very low
average
average
very low
low
average
average
low

Source: ROA 
Table 3.17

Most important economic sectors per type of education, average 1993-1994

\begin{tabular}{llc}
\hline Type of education & $\%$ & trend \\
$1992-94$
\end{tabular}

\section{Primary Education}

\section{Primary Education}

\section{Commerce}

Metal and electrical industries

Other commercial services

Construction

Transport, storage and communication

Non-commercial services

Other industry

Agriculture and fisheries

Food and beverage industry

\section{LGSE, PVE}

\section{Lower General Secondary Education}

Commerce

Other commercial services

Non-commercial services

Civil service, police, defense and education

Transport, storage and communication

Metal and electrical industries

Financial services

$\begin{aligned} 15 & \text { constant } \\ 14 & \text { falling } \\ 13 & - \\ 11 & - \\ 10 & \text { rising } \\ 8 & \text { constant } \\ 7 & - \\ 5 & - \\ 5 & \text { falling }\end{aligned}$

PVE Agriculture

Agriculture and fisheries

Commerce

Transport, storage and communication

Civil service, police, defense and education

Metal and electrical industries

Construction

22
14
11
11
9
7

22
14
11
11
9
7
5

rising

-

falling

-

rising
rising
rising strongly
rising strongly

PVE Construction trades

Construction

Other industry

Commerce

Metal and electrical industries

Transport, storage and communication

Other commercial services

51
10
6
6
6
5

-

rising

rising strongly

falling

rising

falling

rising strongly

PVE Utilities installation

Construction

Metal and electrical industries

Commerce

rising

$-$

rising

falling

falling strongly

rising strongly

falling

constant 
Table 3.17 (continued)

Most important economic sectors per type of education, average 1993-1994

\begin{tabular}{|c|c|c|}
\hline Type of education & $\%$ & $\begin{array}{l}\text { trend } \\
1992-' 94\end{array}$ \\
\hline \multicolumn{3}{|l|}{ PVE Automobile trades } \\
\hline Other commercial services & 22 & rising \\
\hline Commerce & 16 & rising strongly \\
\hline Transport, storage and communication & 16 & - \\
\hline Metal and electrical industries & 10 & falling strongly \\
\hline Construction & 8 & - \\
\hline Civil service, police, defense and education & 7 & falling \\
\hline Other industry & 5 & - \\
\hline \multicolumn{3}{|l|}{ PVE Electrical trades } \\
\hline Metal and electrical industries & 20 & - \\
\hline Construction & 19 & - \\
\hline Commerce & 15 & rising strongly \\
\hline Transport, storage and communication & 11 & - \\
\hline Other commercial services & 8 & - \\
\hline Other industry & 5 & - \\
\hline \multicolumn{3}{|l|}{ PVE Printing trades } \\
\hline Other industry & 45 & falling \\
\hline \multicolumn{3}{|l|}{ PVE Food trades } \\
\hline Food and beverage industry & 26 & falling \\
\hline Commerce & 19 & falling \\
\hline Other commercial services & 15 & rising strongly \\
\hline Transport, storage and communication & 8 & rising \\
\hline Metal and electrical industries & 7 & - \\
\hline Construction & 6 & - \\
\hline \multicolumn{3}{|l|}{ PVE Textile and leather trades } \\
\hline Commerce & 30 & rising \\
\hline Non-commercial services & 13 & - \\
\hline Other industry & 12 & - \\
\hline Other commercial services & 10 & falling strongly \\
\hline Metal and electrical industries & 7 & falling \\
\hline Food and beverage industry & 6 & rising strongly \\
\hline Agriculture and fisheries & 5 & - \\
\hline \multicolumn{3}{|l|}{ PVE Transport and harbour } \\
\hline Transport, storage and communication & 55 & - \\
\hline Commerce & 12 & - \\
\hline Construction & 6 & rising strongly \\
\hline Other commercial services & 5 & rising strongly \\
\hline \multicolumn{3}{|l|}{ PVE Administration } \\
\hline Commerce & 24 & - \\
\hline Other commercial services & 13 & - \\
\hline Civil service, police, defense and education & 11 & rising \\
\hline Transport, storage and communication & 9 & rising strongly \\
\hline Non-commercial services & 9 & - \\
\hline Metal and electrical industries & 8 & - \\
\hline Financial services & 7 & falling strongly \\
\hline
\end{tabular}


Table 3.17 (continued)

Most important economic sectors per type of education, average 1993-1994

\begin{tabular}{|c|c|c|}
\hline Type of education & $\%$ & $\begin{array}{l}\text { trend } \\
1992-94\end{array}$ \\
\hline \multicolumn{3}{|l|}{ PVE Commerce } \\
\hline Commerce & 44 & falling strongly \\
\hline Other commercial services & 9 & - 50 \\
\hline Non-commercial services & 8 & falling strongly \\
\hline Food and beverage industry & 6 & rising strongly \\
\hline Transport, storage and communication & 6 & - \\
\hline Metal and electrical industries & 5 & rising strongly \\
\hline \multicolumn{3}{|l|}{ PVE Community care, hotel and catering } \\
\hline Commerce & 24 & - \\
\hline Non-commercial services & 21 & falling \\
\hline Other commercial services & 18 & constant \\
\hline Agriculture and fisheries & 8 & - \\
\hline Metal and electrical industries & 6 & rising \\
\hline Civil service, police, defense and education & 5 & constant \\
\hline \multicolumn{3}{|l|}{ PVE Security } \\
\hline Other commercial services & 36 & rising strongly \\
\hline Civil service, police, defense and education & 22 & falling strongly \\
\hline Transport, storage and communication & 13 & - \\
\hline \multicolumn{3}{|l|}{ HGSE, IVE } \\
\hline \multicolumn{3}{|l|}{ Higher General Secondary Education } \\
\hline Other commercial services & 20 & rising \\
\hline Commerce & 16 & - \\
\hline Civil service, police, defense and education & 13 & - \\
\hline Non-commercial services & 12 & constant \\
\hline Financial services & 9 & - \\
\hline Transport, storage and communication & 8 & - \\
\hline \multicolumn{3}{|l|}{ IVE Agriculture and the natural environment } \\
\hline Agriculture and fisheries & 56 & constant \\
\hline Commerce & 14 & rising \\
\hline Civil service, police, defense and education & 8 & - \\
\hline \multicolumn{3}{|l|}{ IVE Technical Laboratory } \\
\hline Chemicals & 17 & falling strongly \\
\hline Civil service, police, defense and education & 16 & - \\
\hline Other commercial services & 14 & falling strongly \\
\hline Non-commercial services & 13 & - \\
\hline Food and beverage industry & 8 & - \\
\hline Metal and electrical industries & 8 & rising strongly \\
\hline \multicolumn{3}{|l|}{ IVE Construction technology } \\
\hline Construction & 58 & constant \\
\hline Other industry & 7 & rising strongly \\
\hline Other commercial services & 7 & falling \\
\hline Commerce & 6 & - \\
\hline Metal and electrical industries & 5 & - \\
\hline Civil service, police, defense and education & 5 & falling \\
\hline
\end{tabular}


Table 3.17 (continued)

Most important economic sectors per type of education, average 1993-1994

\begin{tabular}{|c|c|c|}
\hline Type of education & $\%$ & $\begin{array}{l}\text { trend } \\
1992-' 94\end{array}$ \\
\hline \multicolumn{3}{|l|}{ IVE Civil engineering } \\
\hline Construction & 37 & rising \\
\hline Civil service, police, defense and education & 34 & rising \\
\hline Other commercial services & 10 & falling strongly \\
\hline Transport, storage and communication & 5 & - \\
\hline \multicolumn{3}{|l|}{ IVE Metalworking } \\
\hline Metal and electrical industries & 53 & falling \\
\hline Commerce & 9 & rising strongly \\
\hline Construction & 7 & falling \\
\hline Transport, storage and communication & 6 & rising strongly \\
\hline \multicolumn{3}{|l|}{ IVE Precision engineering } \\
\hline Metal and electrical industries & 34 & falling strongly \\
\hline Commerce & 22 & - \\
\hline Civil service, police, defense and education & 13 & - \\
\hline Non-commercial services & 8 & - \\
\hline Other commercial services & 7 & - \\
\hline \multicolumn{3}{|l|}{ IVE Mechanical engineering } \\
\hline Metal and electrical industries & 33 & constant \\
\hline Construction & 11 & - \\
\hline Commerce & 11 & rising strongly \\
\hline Other commercial services & 9 & - \\
\hline Transport, storage and communication & 7 & - \\
\hline Civil service, police, defense and education & 5 & - \\
\hline Other industry & 5 & - \\
\hline Energy & 5 & - \\
\hline Chemicals & 5 & falling strongly \\
\hline \multicolumn{3}{|l|}{ IVE Automobile technology } \\
\hline Other commercial services & 38 & falling \\
\hline Commerce & 21 & - \\
\hline Transport, storage and communication & 13 & - \\
\hline Metal and electrical industries & 10 & - \\
\hline \multicolumn{3}{|l|}{ IVE Electrical technology } \\
\hline Metal and electrical industries & 21 & falling \\
\hline Construction & 19 & - \\
\hline Commerce & 15 & constant \\
\hline Transport, storage and communication & 10 & - \\
\hline Other commercial services & 8 & rising \\
\hline Energy & 6 & - \\
\hline Civil service, police, defense and education & 6 & rising strongly \\
\hline \multicolumn{3}{|l|}{ IVE Printing technology } \\
\hline Other industry & 60 & - \\
\hline Other commercial services & 12 & - \\
\hline Commerce & 9 & rising \\
\hline Metal and electrical industries & 5 & falling \\
\hline \multicolumn{3}{|l|}{ IVE Food technology } \\
\hline Food and beverage industry & 41 & - \\
\hline Commerce & 37 & rising \\
\hline Other commercial services & 7 & rising strongly \\
\hline
\end{tabular}


Table 3.17 (continued)

Most important economic sectors per type of education, average 1993-1994

Type of education $\quad \% \quad$ trend

1992-'94

IVE Process technologies

Chemicals

Metal and electrical industries

Food and beverage industry

Civil service, police, defense and education

Energy

IVE Textile and leather technology

Commerce

Other industry

Other commercial services

Non-commercial services

Civil service, police, defense and education

Metal and electrical industries

7

\section{8}

14

12

6

5

IVE Transport and harbour

Transport, storage and communication

Commerce

Metal and electrical industries

Other commercial services

IVE Nursing and paramedical services

Non-commercial services

IVE Medical laboratory

Commerce

Non-commercial services

Metal and electrical industries

IVE Retail

Commerce

Other commercial services

Civil service, police, defense and education Non-commercial services

Transport, storage and communication

Metal and electrical industries

Construction

Financial services

\section{IVE Administration}

Other commercial services

Civil service, police, defense and education

Commerce

Financial services

Non-commercial services

Construction

Metal and electrical industries

Transport, storage and communication

IVE Tourism and recreation

Transport, storage and communication

Financial services

Other commercial services

Non-commercial services

Commerce

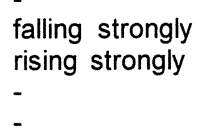

falling strongly rising strongly

-

falling

rising

rising strongly

falling

rising strongly

rising strongly

constant

constant

rising strongly

constant

rising

constant

falling

constant

falling

rising strongly

constant

falling strongly

rising

rising

rising strongly 
Table 3.17 (continued)

Most important economic sectors per type of education, average 1993-1994

\begin{tabular}{|c|c|c|}
\hline Type of education & $\%$ & $\begin{array}{l}\text { trend } \\
1992-' 94\end{array}$ \\
\hline \multicolumn{3}{|l|}{ IVE Commerce } \\
\hline Commerce & 22 & - \\
\hline Financial services & 17 & - \\
\hline Other commercial services & 11 & - \\
\hline Construction & 8 & - \\
\hline Metal and electrical industries & 7 & falling \\
\hline Transport, storage and communication & 7 & rising strongly \\
\hline Civil service, police, defense and education & 7 & - \\
\hline Other industry & 5 & rising strongly \\
\hline \multicolumn{3}{|l|}{ IVE Secretarial } \\
\hline Non-commercial services & 23 & - \\
\hline Other commercial services & 16 & rising \\
\hline Commerce & 14 & constant \\
\hline Civil service, police, defense and education & 14 & falling \\
\hline Financial services & 7 & falling strongly \\
\hline Metal and electrical industries & 6 & - \\
\hline \multicolumn{3}{|l|}{ IVE Legal and fiscal } \\
\hline Civil service, police, defense and education & 71 & constant \\
\hline Other commercial services & 10 & - \\
\hline \multicolumn{3}{|l|}{ IVE Social and cultural } \\
\hline Non-commercial services & 46 & - \\
\hline Civil service, police, defense and education & 26 & rising \\
\hline Other commercial services & 5 & - \\
\hline \multicolumn{3}{|l|}{ IVE Community care } \\
\hline Non-commercial services & 49 & - \\
\hline Other commercial services & 21 & rising \\
\hline Commerce & 10 & falling \\
\hline Civil service, police, defense and education & 5 & rising \\
\hline \multicolumn{3}{|l|}{ IVE Hotel, catering and hairdressing } \\
\hline Other commercial services & 57 & - \\
\hline Commerce & 11 & - \\
\hline Non-commercial services & 10 & rising strongly \\
\hline Civil service, police, defense and education & 5 & - \\
\hline \multicolumn{3}{|l|}{ IVE Police, fire and defense } \\
\hline Civil service, police, defense and education & 64 & falling \\
\hline Transport, storage and communication & 6 & rising strongly \\
\hline Other commercial services & 6 & rising strongly \\
\hline \multicolumn{3}{|l|}{ HVE } \\
\hline \multicolumn{3}{|l|}{ HVE Teacher training } \\
\hline Civil service, police, defense and education & 71 & constant \\
\hline Non-commercial services & 11 & - \\
\hline \multicolumn{3}{|l|}{ HVE Interpreter and translator } \\
\hline Civil service, police, defense and education & 25 & rising strongly \\
\hline $\begin{array}{l}\text { Non-commercial services } \\
\text { Other commercial services }\end{array}$ & $\begin{array}{l}16 \\
16\end{array}$ & falling strongly \\
\hline
\end{tabular}


Table 3.17 (continued)

Most important economic sectors per type of education, average 1993-1994

\begin{tabular}{lll}
\hline Type of education & $\%$ & trend \\
$1992-94$
\end{tabular}

HVE Agriculture and environmental science

Civil service, police, defense and education

Agriculture and fisheries

Other commercial services

Non-commercial services

Commerce

Food and beverage industry

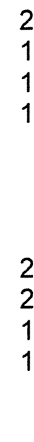

Civil service, police, defense and education Non-commercial services

Chemicals

Other commercial services

Commerce

Metal and electrical industries

HVE Construction and civil engineering

Other commercial services

Civil service, police, defense and education

Construction

HVE Mechanical engineering

Metal and electrical industries

Other commercial services

Commerce

Civil service, police, defense and education Energy

HVE Electronic and information technology

Metal and electrical industries

Other commercial services

Commerce

Civil service, police, defense and education

Transport, storage and communication

Energy

Non-commercial services

HVE Transport and harbour

Transport, storage and communication

Other commercial services

Metal and electrical industries

Civil service, police, defense and education

Energy

Commerce

HVE Medical laboratory

Non-commercial services

Civil service, police, defense and education

HVE Nursing and paramedical services

Non-commercial services

Civil service, police, defense and education
1992-'94

rising

rising strongly

rising strongly

constant

falling strongly

falling strongly

falling strongly

rising

rising strongly

rising strongly

rising strongly

rising strongly

rising strongly

falling strongly

rising

-

rising strongly

constant

rising strongly 
Table 3.17 (continued)

Most important economic sectors per type of education, average 1993-1994

\begin{tabular}{|c|c|c|}
\hline Type of education & $\%$ & $\begin{array}{l}\text { trend } \\
1992-' 94\end{array}$ \\
\hline \multicolumn{3}{|l|}{ HVE Business administration } \\
\hline Other commercial services & 27 & rising strongly \\
\hline Financial services & 13 & falling strongly \\
\hline Commerce & 13 & falling strongly \\
\hline Civil service, police, defense and education & 11 & falling strongly \\
\hline Metal and electrical industries & 8 & - \\
\hline Transport, storage and communication & 6 & - \\
\hline Non-commercial services & 5 & rising strongly \\
\hline \multicolumn{3}{|l|}{ HVE Accounting } \\
\hline Other commercial services & 36 & falling \\
\hline Civil service, police, defense and education & 13 & falling strongly \\
\hline Financial services & 10 & - \\
\hline Commerce & 9 & falling \\
\hline Non-commercial services & 7 & rising strongly \\
\hline Construction & 6 & rising strongly \\
\hline Metal and electrical industries & 5 & - \\
\hline \multicolumn{3}{|l|}{ HVE Commercial information science } \\
\hline Other commercial services & 29 & - \\
\hline Civil service, police, defense and education & 14 & rising \\
\hline Financial services & 12 & rising strongly \\
\hline Commerce & 10 & - \\
\hline Metal and electrical industries & 9 & falling strongly \\
\hline Transport, storage and communication & 6 & falling strongly \\
\hline Non-commercial services & 6 & - \\
\hline \multicolumn{3}{|l|}{ HVE Tourism and recreation } \\
\hline Transport, storage and communication & 29 & - \\
\hline Other commercial services & 19 & - \\
\hline Non-commercial services & 17 & - \\
\hline \multicolumn{3}{|l|}{ HVE Commerce } \\
\hline Commerce & 26 & - \\
\hline Financial services & 16 & - \\
\hline Metal and electrical industries & 12 & rising strongly \\
\hline Other commercial services & 10 & falling strongly \\
\hline Other industry & 6 & falling strongly \\
\hline Food and beverage industry & 5 & - \\
\hline \multicolumn{3}{|l|}{ HVE Business administration technology } \\
\hline Commerce & 20 & - \\
\hline Other commercial services & 19 & - \\
\hline Metal and electrical industries & 16 & falling strongly \\
\hline Financial services & 12 & - \\
\hline \multicolumn{3}{|l|}{ HVE Legal and fiscal } \\
\hline Civil service, police, defense and education & 56 & rising \\
\hline Other commercial services & 17 & - \\
\hline Financial services & 7 & falling strongly \\
\hline Commerce & 6 & - \\
\hline Non-commercial services & 5 & - \\
\hline \multicolumn{3}{|l|}{ HVE Social and cultural } \\
\hline Non-commercial services & 48 & constant \\
\hline Civil service, police, defense and education & 25 & rising \\
\hline Other commercial services & 8 & falling \\
\hline
\end{tabular}


Table 3.17 (continued)

Most important economic sectors per type of education, average 1993-1994

\begin{tabular}{lll}
\hline Type of education & $\%$ & trend \\
& $1992-94$
\end{tabular}

HVE Fine Arts

Non-commercial services

Other commercial services

45

20

Civil service, police, defense and education

Commerce

Other industry

HVE Police, fire and defense

Civil service, police, defense and education

UE

\section{UE Arts}

Civil service, police, defense and education Non-commercial services

Other commercial services

UE Theology

Non-commercial services

Civil service, police, defense and education

UE Agriculture and environmental science

Civil service, police, defense and education

Other commercial services

Non-commercial services

UE Mathematics and natural sciences

Civil service, police, defense and education Non-commercial services

Other commercial services

Chemicals

Mechanical and electrical engineering

UE Construction and civil engineering

Other commercial services

Civil service, police, defense and education Construction

Non-commercial services

UE Mechanical engineering

Metal and electrical industries

Civil service, police, defense and education

Other commercial services

\section{UE Pharmacy}

\section{Commerce}

Civil service, police, defense and education rising

rising strongly

rising

falling strongly

falling strongly

falling

falling

rising strongly

falling strongly

rising

rising strongly

falling strongly$$
-
$$$$
\text { rising }
$$

falling strongly rising strongly

constant

falling strongly

falling

rising strongly

UE Economics, econometrics and business administration Other commercial services

Civil service, police, defense and education 22

Financial services

Commerce

Non-commercial services

Metal and electrical industries

falling

$-$ 
Table 3.17 (continued)

Most important economic sectors per type of education, average 1993-1994

\begin{tabular}{|c|c|c|}
\hline Type of education & $\%$ & $\begin{array}{l}\text { trend } \\
1992-' 94\end{array}$ \\
\hline \multicolumn{3}{|l|}{ UE Management science } \\
\hline Other commercial services & 30 & - \\
\hline Transport, storage and communication & 14 & rising strongly \\
\hline Civil service, police, defense and education & 10 & - \\
\hline Metal and electrical industries & 9 & rising strongly \\
\hline \multicolumn{3}{|l|}{ UE Information science } \\
\hline Civil service, police, defense and education & 36 & rising strongly \\
\hline Other commercial services & 27 & - \\
\hline \multicolumn{3}{|l|}{ UE Law } \\
\hline Civil service, police, defense and education & 37 & rising strongly \\
\hline Other commercial services & 33 & - \\
\hline Financial services & 9 & rising strongly \\
\hline Non-commercial services & 7 & falling strongly \\
\hline \multicolumn{3}{|l|}{ UE Public administration } \\
\hline Other commercial services & 41 & rising strongly \\
\hline Civil service, police, defense and education & 40 & - \\
\hline \multicolumn{3}{|l|}{ UE Social sciences } \\
\hline Civil service, police, defense and education & 39 & rising \\
\hline Non-commercial services & 37 & falling \\
\hline Other commercial services & 9 & falling \\
\hline \multicolumn{3}{|l|}{ UE Fine Arts } \\
\hline Civil service, police, defense and education & 52 & - \\
\hline Non-commercial services & 26 & - \\
\hline
\end{tabular}

Source: CBS/ROA 
Table 3.18

Opportunities to switch to other economic sub-sectors per type of education, average 1993-1994

\begin{tabular}{lll}
\hline Type of education & $\begin{array}{l}\text { Gini-Hirschman } \\
\text { dispersion index }\end{array}$ & $\begin{array}{l}\text { qualitative } \\
\text { charact. }\end{array}$ \\
\hline
\end{tabular}

\section{Primary Education}

Primary Education

very high

\section{LGSE, PVE}

Lower General Secondary Education

PVE Agriculture

$\begin{array}{ll}0.98 & \text { very high } \\ 0.76 & \text { low } \\ 0.84 & \text { average } \\ 0.87 & \text { average } \\ 0.97 & \text { very high } \\ 0.95 & \text { high } \\ 0.96 & \text { high } \\ 0.81 & \text { average } \\ 0.92 & \text { average } \\ 0.95 & \text { high } \\ 0.82 & \text { average } \\ 0.97 & \text { very high } \\ 0.91 & \text { average } \\ 0.95 & \text { high } \\ 0.84 & \text { average }\end{array}$

inction trades

PVE Mechanical trades

PVE Automobile trades

PVE Electrical trades

PVE Printing trades

PVE Food trades

PVE Textile and leather trades

PVE Transport and harbour

PVE Administration

PVE Commerce

PVE Community care, hotel and catering

PVE Security

average

\section{HGSE, IVE}

Higher General Secondary Education

IVE Agriculture and the natural environment

IVE Technical Laboratory

IVE Construction technology

IVE Civil engineering

IVE Metalworking

IVE Precision engineering

IVE Mechanical engineering

IVE Automobile technology

IVE Electrical technology

IVE Printing technology

IVE Food technology

IVE Process technologies

IVE Textile and leather technology

IVE Transport and harbour

IVE Nursing and paramedical services

IVE Medical laboratory

IVE Retail

IVE Administration

IVE Tourism and recreation

IVE Commerce

IVE Secretarial

IVE Legal and fiscal

VOcial and cultura

IVE Community care

IVE Hotel, catering and hairdressing 
Table 3.18 (continued)

Opportunities to switch to other economic sub-sectors per type of education, average 1993-1994

\begin{tabular}{lll}
\hline Type of education & $\begin{array}{l}\text { Gini-Hirschman } \\
\text { dispersion index }\end{array}$ & $\begin{array}{l}\text { qualitative } \\
\text { charact. }\end{array}$ \\
\hline
\end{tabular}

HVE

HVE Teacher training

HVE Interpreter and translator

HVE Agriculture and environmental science

HVE Construction and civil engineering

HVE Mechanical engineering

HVE Electronic and information technology

HVE Transport and harbour

HVE Medical laboratory

HVE Nursing and paramedical services

0.95

0.52

0.45

HVE Business administration

HVE Accounting

HVE Commercial information science

HVE Tourism and recreation

HVE Commerce

HVE Business administration technology

HVE Legal and fiscal

HVE Social and cultural

HVE Fine Arts

HVE Police, fire and defense

UE

UE Arts

UE Theology

UE Agriculture and environmental science

0.65

UE Mathematics and natural sciences

UE Construction and civil engineering

UE Mechanical engineering

UE Electrical engineering and information technology

UE Veterinary and medical sciences and dentistry

UE Economics, econometrics and business administration

UE Management science

UE Information science

UE Law

0.79

UE Public administration

Source: ROA 
Table 3.19

Overview of types of education facing (strong) competition on the labour market

\begin{tabular}{lc}
\hline Type of education & index of com \\
\hline Primary Education & \\
& \\
PVE Community care, hotel and catering & 0.69 \\
PVE Textile and leather trades & 0.63 \\
Lower General Secondary Education & 0.61 \\
IVE Transport and harbour & 0.52 \\
PVE Transport and harbour & 0.51 \\
IVE Retail & 0.49 \\
PVE Mechanical trades & 0.48 \\
PVE Commerce & 0.44 \\
PVE Automobile trades & 0.41 \\
Higher General Secondary Education & 0.39 \\
PVE Construction trades & 0.38 \\
PVE Administration & 0.38 \\
IVE Textile and leather technology & 0.33 \\
PVE Agriculture & 0.32 \\
IVE Community care & 0.32 \\
PVE Electrical trades & 0.31
\end{tabular}

\section{Lower General Secondary Education}

Higher General Secondary Education 0.92

IVE Retail $\quad 0.91$

PVE Administration $\quad 0.89$

IVE Commerce $\quad 0.75$

PVE Community care, hotel and catering $\quad 0.75$

PVE Commerce $\quad 0.71$

IVE Administration $\quad 0.63$

IVE Textile and leather technology $\quad 0.62$

Primary Education $\quad 0.61$

IVE Legal and fiscal $\quad 0.60$

IVE Secretarial $\quad 0.58$

HVE Business administration $\quad 0.57$

PVE Textile and leather trades 0.56

HVE Legal and fiscal 0.48

HVE Commerce $\quad 0.48$

IVE Tourism and recreation $\quad 0.42$

IVE Community care $\quad 0.41$

IVE Social and cultural $\quad 0.39$

IVE Transport and harbour $\quad 0.37$

HVE Accounting $\quad 0.31$

\section{PVE Agriculture}

IVE Agriculture and the natural environment 0.97

HVE Agriculture and environmental science $\quad 0.42$

Primary Education $\quad 0.32$

\section{PVE Construction trades}

IVE Construction technology

Primary Education $\quad 0.38$

PVE Utilities installation 
Table 3.19 (continued)

Overview of types of education facing (strong) competition on the labour market

Type of education index of competition

PVE Mechanical trades

IVE Metalworking

IVE Mechanical engineering

Primary Education

0.48

PVE Transport and harbour

0.41

IVE Transport and harbour

0.35

PVE Automobile trades

0.35

PVE Electrical trades

\section{PVE Automobile trades}

IVE Automobile technology

IVE Transport and harbour $\quad 0.48$

Primary Education

PVE Mechanical trades

\section{PVE Electrical trades}

IVE Electrical technology

Primary Education

PVE Mechanical trades

\section{PVE Printing trades}

IVE Printing technology

PVE Food trades

IVE Food technology

PVE Textile and leather trades

PVE Community care, hotel and catering 0.81

0.81

IVE Textile and leather technology $\quad 0.69$

Primary Education $\quad 0.63$

IVE Retail $\quad 0.59$

Lower General Secondary Education $\quad 0.56$

PVE Administration $\quad 0.42$

IVE Community care $\quad 0.39$

IVE Precision engineering $\quad 0.33$

Higher General Secondary Education $\quad 0.30$

PVE Transport and harbour

IVE Transport and harbour $\quad 0.79$

PVE Automobile trades $\quad 0.59$

Primary Education $\quad 0.51$

PVE Mechanical trades $\quad 0.41$ 
Table 3.19 (continued)

Overview of types of education facing (strong) competition on the labour market

Type of education

index of competition

\section{PVE Administration}

Lower General Secondary Education $\quad 0.89$

Higher General Secondary Education $\quad 0.86$

IVE Administration $\quad 0.84$

IVE Retail $\quad 0.83$

HVE Business administration $\quad 0.79$

IVE Commerce $\quad 0.75$

PVE Commerce $\quad 0.66$

IVE Legal and fiscal $\quad 0.65$

PVE Community care, hotel and catering 0.58

IVE Textile and leather technology $\quad 0.57$

HVE Legal and fiscal $\quad 0.51$

IVE Secretarial $\quad 0.50$

HVE Accounting $\quad 0.45$

PVE Textile and leather trades $\quad 0.42$

HVE Commerce $\quad 0.42$

IVE Tourism and recreation $\quad 0.41$

Primary Education $\quad 0.38$

\section{PVE Commerce}

IVE Textile and leather technology $\quad 0.87$

PVE Textile and leather trades $\quad 0.81$

IVE Retail $\quad 0.79$

PVE Community care, hotel and catering $\quad 0.76$

Lower General Secondary Education $\quad 0.71$

Higher General Secondary Education $\quad 0.52$

IVE Commerce $\quad 0.46$

Primary Education $\quad 0.44$

IVE Precision engineering $\quad 0.39$

HVE Commerce $\quad 0.32$

IVE Administration $\quad 0.31$

PVE Community care, hotel and catering

PVE Textile and leather trades

Lower General Secondary Education $\quad 0.75$

Primary Education $\quad 0.69$

$\begin{array}{ll}\text { IVE Retail } & 0.67\end{array}$

IVE Textile and leather technology $\quad 0.63$

PVE Administration $\quad 0.58$

IVE Community care $\quad 0.58$

Higher General Secondary Education $\quad 0.56$

IVE Commerce $\quad 0.40$

IVE Hotel, catering and hairdressing $\quad 0.37$

IVE Social and cultural $\quad 0.33$

IVE Administration $\quad 0.30$

\section{PVE Security}


Table 3.19 (continued)

Overview of types of education facing (strong) competition on the labour market

\begin{tabular}{lc}
\hline Type of education & index of com \\
\hline & \\
\hline Higher General Secondary Education & \\
Lower General Secondary Education & \\
PVE Administration & 0.92 \\
IVE Retail & 0.86 \\
IVE Commerce & 0.82 \\
IVE Legal and fiscal & 0.80 \\
IVE Administration & 0.70 \\
IVE Secretarial & 0.70 \\
HVE Business administration & 0.67 \\
HVE Legal and fiscal & 0.64 \\
PVE Commerce & 0.59 \\
HVE Commerce & 0.52 \\
IVE Tourism and recreation & 0.51 \\
IVE Textile and leather technology & 0.47 \\
IVE Social and cultural & 0.47 \\
Primary Education & 0.41 \\
HVE Accounting & 0.39 \\
UE Economics, econometrics and business administration & 0.38 \\
IVE Community care & 0.34 \\
IVE Transport and harbour & 0.34 \\
PVE Textile and leather trades & 0.31 \\
\end{tabular}

PVE Textile and leather trades $\quad 0.30$

IVE Agriculture and the natural environment

PVE Agriculture $\quad 0.97$

HVE Agriculture and environmental science $\quad 0.44$

IVE Technical Laboratory

HVE Technical laboratory 0.98

HVE Medical laboratory $\quad 0.36$

\section{IVE Construction technology}

PVE Construction trades 0.83

IVE Civil engineering $\quad 0.33$

IVE Civil engineering

HVE Construction and civil engineering 0.43

IVE Construction technology 0.33

IVE Metalworking

PVE Mechanical trades

IVE Mechanical engineering $\quad 0.60$

IVE Precision engineering

PVE Commerce

IVE Textile and leather technology

PVE Textile and leather trades 0.33 
Table 3.19 (continued)

Overview of types of education facing (strong) competition on the labour market

Type of education

index of competition

\section{IVE Mechanical engineering}

IVE Metalworking

PVE Mechanical trades

HVE Mechanical engineering

IVE Electrical technology

IVE Automobile technology

\section{IVE Automobile technology}

PVE Automobile trades

IVE Mechanical engineering

\section{IVE Electrical technology}

PVE Electrical trades

IVE Mechanical engineering

\section{IVE Printing technology}

PVE Printing trades

\section{IVE Food technology}

PVE Food trades

IVE Process technologies

\section{IVE Textile and leather technology}

PVE Commerce $\quad 0.87$

IVE Retail

PVE Textile and leather trades 0.69

PVE Community care, hotel and catering 0.63

Lower General Secondary Education $\quad 0.62$

PVE Administration $\quad 0.57$

Higher General Secondary Education $\quad 0.47$

IVE Commerce 0.44

IVE Precision engineering $\quad 0.36$

HVE Commerce 0.34

Primary Education $\quad 0.33$

\section{IVE Transport and harbour}

PVE Transport and harbour $\quad 0.79$

Primary Education $\quad 0.52$

0.48

Lower General Secondary Education $\quad 0.37$

PVE Mechanical trades 0.35

Higher General Secondary Education $\quad 0.31$

IVE Nursing and paramedical services

HVE Nursing and paramedical services

IVE Social and cultural $\quad 0.36$

IVE Community care 0.33 
Table 3.19 (continued)

Overview of types of education facing (strong) competition on the labour market

Type of education index of competition

IVE Medical laboratory

\section{IVE Retail}

Lower General Secondary Education

PVE Administration

Higher General Secondary Education

PVE Commerce

IVE Commerce

0.72

IVE Textile and leather technology

PVE Community care, hotel and catering $\quad 0.67$

PVE Textile and leather trades $\quad 0.59$

IVE Administration $\quad 0.55$

HVE Business administration $\quad 0.49$

Primary Education $\quad 0.49$

IVE Legal and fiscal $\quad 0.48$

IVE Secretarial $\quad 0.48$

HVE Commerce $\quad 0.48$

HVE Legal and fiscal $\quad 0.41$

IVE Tourism and recreation $\quad 0.34$

\section{IVE Administration}

$\begin{array}{ll}\text { HVE Business administration } & 0.99\end{array}$

PVE Administration $\quad 0.84$

HVE Accounting $\quad 0.70$

Higher General Secondary Education $\quad 0.70$

Lower General Secondary Education $\quad 0.63$

IVE Commerce $\quad 0.60$

IVE Legal and fiscal $\quad 0.56$

IVE Retail $\quad 0.55$

HVE Legal and fiscal $\quad 0.44$

IVE Tourism and recreation $\quad 0.41$

UE Economics, econometrics and business administration 0.38

IVE Secretarial $\quad 0.35$

PVE Commerce $\quad 0.31$

PVE Community care, hotel and catering $\quad 0.30$

\section{IVE Tourism and recreation}

HVE Tourism and recreation $\quad 0.86$

IVE Secretarial $\quad 0.50$

Higher General Secondary Education $\quad 0.47$

Lower General Secondary Education $\quad 0.42$

IVE Administration $\quad 0.41$

PVE Administration $\quad 0.41$

HVE Business administration $\quad 0.39$

IVE Retail $\quad 0.34$

$\begin{array}{lr}\text { IVE Commerce } & 0.32\end{array}$ 
Table 3.19 (continued)

Overview of types of education facing (strong) competition on the labour market

Type of education

index of competition

\section{IVE Commerce}

Higher General Secondary Education $\quad 0.80$

Lower General Secondary Education $\quad 0.75$

PVE Administration $\quad 0.75$

IVE Retail $\quad 0.72$

IVE Legal and fiscal $\quad 0.71$

HVE Commerce $\quad 0.65$

IVE Administration $\quad 0.60$

HVE Legal and fiscal $\quad 0.57$

HVE Business administration $\quad 0.56$

IVE Secretarial $\quad 0.52$

0.46

IVE Textile and leather technology $\quad 0.44$

PVE Community care, hotel and catering $\quad 0.40$

IVE Tourism and recreation $\quad 0.32$

HVE Accounting $\quad 0.30$

\section{IVE Secretarial}

Higher General Secondary Education $\quad 0.67$

Lower General Secondary Education $\quad 0.58$

IVE Commerce $\quad 0.52$

IVE Tourism and recreation $\quad 0.50$

PVE Administration $\quad 0.50$

IVE Legal and fiscal $\quad 0.41$

HVE Legal and fiscal $\quad 0.36$

IVE Administration $\quad 0.35$

\section{IVE Legal and fiscal}

$\begin{array}{ll}\text { HVE Legal and fiscal } & 0.77\end{array}$

IVE Commerce $\quad 0.71$

Higher General Secondary Education $\quad 0.70$

PVE Administration $\quad 0.65$

Lower General Secondary Education $\quad 0.60$

HVE Commerce $\quad 0.59$

HVE Business administration $\quad 0.53$

IVE Retail $\quad 0.48$

IVE Secretarial $\quad 0.41$

UE Economics, econometrics and business administration $\quad 0.37$

UE Law $\quad 0.34$

IVE Social and cultural

$\begin{array}{ll}\text { HVE Social and cultural } & 0.75\end{array}$

IVE Community care $\quad 0.67$

Higher General Secondary Education $\quad 0.41$

Lower General Secondary Education $\quad 0.39$

IVE Nursing and paramedical services $\quad 0.36$

UE Social sciences $\quad 0.34$

PVE Community care, hotel and catering $\quad 0.33$ 
Table 3.19 (continued)

Overview of types of education facing (strong) competition on the labour market

Type of education index of competition

IVE Community care

IVE Social and cultural

PVE Community care, hotel and catering

Lower General Secondary Education

PVE Textile and leather trades

0.39

IVE Hotel, catering and hairdressing

0.38

Higher General Secondary Education

0.34

IVE Nursing and paramedical services

0.33

Primary Education

IVE Hotel, catering and hairdressing

IVE Community care

PVE Community care, hotel and catering

IVE Police, fire and defense

HVE Police, fire and defense

HVE Teacher training

HVE Interpreter and translator

HVE Agriculture and environmental science

IVE Agriculture and the natural environment

PVE Agriculture

UE Agriculture and environmental science

HVE Technical laboratory

IVE Technical Laboratory

HVE Medical laboratory

HVE Construction and civil engineering

IVE Civil engineering

UE Construction and civil engineering

HVE Mechanical engineering

UE Mechanical engineering

HVE Electronic and information technology

UE Electrical engineering and information technology 0.93

HVE Commercial information science $\quad 0.81$

$\begin{array}{ll}\text { UE Information science } & 0.77\end{array}$

HVE Business administration technology $\quad 0.44$ 
Table 3.19 (continued)

Overview of types of education facing (strong) competition on the labour market

Type of education

index of competition

\section{HVE Transport and harbour}

\section{HVE Medical laboratory}

HVE Technical laboratory $\quad 0.47$

IVE Technical Laboratory 0.36

HVE Nursing and paramedical services

IVE Nursing and paramedical services

HVE Business administration

IVE Administration $\quad 0.99$

PVE Administration $\quad 0.79$

HVE Accounting 0.78

Higher General Secondary Education $\quad 0.64$

Lower General Secondary Education $\quad 0.57$

IVE Commerce 0.56

IVE Legal and fiscal $\quad 0.53$

IVE Retail 0.49

HVE Legal and fiscal $\quad 0.45$

UE Economics, econometrics and business administration 0.44

IVE Tourism and recreation $\quad 0.39$

\section{HVE Accounting}

HVE Business administration $\quad 0.78$

UE Economics, econometrics and business administration 0.70

IVE Administration $\quad 0.70$

UE Public administration $\quad 0.67$

PVE Administration $\quad 0.45$

HVE Legal and fiscal $\quad 0.42$

Higher General Secondary Education 0.38

Lower General Secondary Education $\quad 0.31$

IVE Commerce $\quad 0.30$

HVE Commercial information science

UE Information science 0.94

UE Electrical engineering and information technology 0.63

HVE Business administration technology 0.54

HVE Tourism and recreation

IVE Tourism and recreation 
Table 3.19 (continued)

Overview of types of education facing (strong) competition on the labour market

Type of education

index of competition

\section{HVE Commerce}

$\begin{array}{lc}\text { IVE Commerce } & 0.65 \\ \text { IVE Legal and fiscal } & 0.59 \\ \text { Higher General Secondary Education } & 0.51 \\ \text { Lower General Secondary Education } & 0.48 \\ \text { IVE Retail } & 0.48 \\ \text { HVE Legal and fiscal } & 0.47 \\ \text { PVE Administration } & 0.42 \\ \text { UE Economics, econometrics and business administration } & 0.40 \\ \text { IVE Textile and leather technology } & 0.34 \\ \text { PVE Commerce } & 0.32\end{array}$

\section{HVE Business administration technology}

UE Management science $\quad 0.66$

UE Information science $\quad 0.57$

HVE Commercial information science $\quad 0.54$

HVE Electronic and information technology 0.44

UE Electrical engineering and information technology 0.38

\section{HVE Legal and fiscal}

IVE Legal and fiscal

Higher General Secondary Education $\quad 0.59$

IVE Commerce $\quad 0.57$

PVE Administration $\quad 0.51$

UE Law 0.48

Lower General Secondary Education

UE Economics, econometrics and business administration 0.47

HVE Commerce $\quad 0.47$

HVE Business administration $\quad 0.45$

IVE Administration $\quad 0.44$

HVE Accounting $\quad 0.42$

0.41

IVE Secretarial 0.36

UE Public administration $\quad 0.32$

HVE Social and cultural

IVE Social and cultural $\quad 0.75$

UE Social sciences $\quad 0.55$

HVE Fine Arts

HVE Police, fire and defense

$\begin{array}{ll}\text { IVE Police, fire and defense } & 0.47\end{array}$

UE Arts

UE Theology 
Table 3.19 (continued)

Overview of types of education facing (strong) competition on the labour market

Type of education index of competition

UE Agriculture and environmental science

HVE Agriculture and environmental science

UE Mathematics and natural sciences

UE Information science

UE Construction and civil engineering

HVE Construction and civil engineering

UE Mechanical engineering

HVE Mechanical engineering

UE Electrical engineering and information technology

HVE Electronic and information technology 0.93

UE Information science $\quad 0.67$

HVE Commercial information science 0.63

HVE Business administration technology 0.38

UE Veterinary and medical sciences and dentistry

\section{UE Pharmacy}

UE Economics, econometrics and business administration

UE Public administration $\quad 0.71$

HVE Accounting $\quad 0.70$

HVE Legal and fiscal $\quad 0.47$

HVE Business administration $\quad 0.44$

0.40

IVE Administration $\quad 0.38$

IVE Legal and fiscal 0.37

Higher General Secondary Education $\quad 0.34$

UE Management science

HVE Business administration technology 0.66

UE Information science

HVE Commercial information science

0.94

HVE Electronic and information technology 0.77

UE Electrical engineering and information technology 0.67

HVE Business administration technology 0.57

UE Mathematics and natural sciences 
Table 3.19 (continued)

Overview of types of education facing (strong) competition on the labour market

Type of education index of competition

\section{UE Law}

HVE Legal and fiscal

IVE Legal and fiscal

UE Public administration

UE Economics, econometrics and business administration

HVE Accounting

HVE Legal and fiscal

\section{UE Social sciences}

HVE Social and cultural

IVE Social and cultural

\section{UE Fine Arts}

Source: ROA 
Table 3.20

Sensitivity to the state of the business cycle per type of education

Type of education sensitivity to business cycle qualitative

charact.

\section{Primary Education}

Primary Education

LGSE, PVE

Lower General Secondary Education

PVE Agriculture

PVE Construction trades

0.65

PVE Utilities installation

PVE Mechanical trades

1.64

PVE Automobile trades

1.13

1.05

PVE Electrical trades

1.01

PVE Printing trades

PVE Food trades

PVE Textile and leather trades

0.90

0.74

0.69
1.42

PVE Transport and harbour

PVE Administration

0.70

PVE Commerce

PVE Community care, hotel and catering

PVE Security

average

average

very high

very high

high

high

high

average

average

average

very high

average

average

low

very low

HGSE, IVE

Higher General Secondary Education

IVE Agriculture and the natural environment

0.53

IVE Technical Laboratory

0.76

IVE Construction technology

1.27

0.97

IVE Civil engineering

IVE Metalworking

IVE Precision engineering

IVE Mechanical engineering

1.14

0.97

1.02

IVE Automobile technology

IVE Electrical technology

IVE Printing technology

0.92

0.97

0.86

IVE Food technology

IVE Process technologies

0.68

1.05

VE Textile and leather technology

IVE Transport and harbour

IVE Nursing and paramedical services

0.70

0.89

0.43

0.50

IVE Medical laboratory

0.69

IVE Retail

IVE Administration

IVE Tourism and recreation

0.70

0.63

IVE Commerce

IVE Secretarial

IVE Legal and fiscal

0.62

0.61

0.63

0.51

0.51

IVE Community care

IVE Hotel, catering and hairdressing

IVE Police, fire and defense

0.45

0.53

average

low

average

very high

high

high

high

high

average

high

average

average

high

average

average

low

low

average

average

low

low

low

low

low

low

low

low 
Table 3.20 (continued)

Sensitivity to the state of the business cycle per type of education

Type of education sensitivity to business cycle qualitative

charact.

HVE

HVE Teacher training

0.50

HVE Interpreter and translator

HVE Agriculture and environmental science

0.56

0.78

HVE Technical laboratory

HVE Construction and civil engineering

0.88

HVE Mechanical engineering

0.86

HVE Electronic and information technology

HVE Transport and harbour

1.31

0.62

HVE Medical laboratory

HVE Nursing and paramedical services

0.53

0.45

HVE Business administration

0.77

HVE Accounting

HVE Commercial information science

HVE Tourism and recreation $\quad 0.63$

0.69

HVE Business administration technology 0.96

HVE Legal and fiscal $\quad 0.60$

HVE Social and cultural $\quad 0.49$

HVE Police, fire and defense $\quad 0.51$

low

low

average

average

average

average

very high

low

low

low

average

average

very high

low

average

high

low

low

average

low

UE

UE Arts

UE Theology

UE Agriculture and environmental science

UE Mathematics and natural sciences

0.14

0.94

0.94

UE Construction and civil engineering

0.93

UE Mechanical engineering

1.01

UE Electrical engineering and information technology

1.47

UE Veterinary and medical sciences and dentistry

UE Pharmacy

UE Economics, econometrics and business administration

0.48

0.91

UE Management science

UE Information science

0.89

UE Law

1.26

UE Public administration

0.39

UE Social sciences

0.73

UE Fine Arts

low

very low

high

high

average

high

very high

low

low

average

average

very high

very low

average

low

low

Source: ROA 
Table 3.21

Percentage of school-leavers unemployed for 4 months or longer on entering the labour market per field of study, 1994

\begin{tabular}{lll}
\hline Type of education and field of study & $\%$ & qualitative charact. \\
\hline
\end{tabular}

LGSE, PVE

Lower General Secondary Education

PVE Agriculture

PVE Technical

PVE Construction trades

PVE Utilities installation

PVE Mechanical trades

PVE Automobile trades

PVE Electrical trades

PVE Printing trades

PVE Food trades

PVE Textile and leather trades

PVE Commerce and administration

PVE Office administration

PVE Retailing

\section{PVE Personal services}

PVE Community care, hotel and catering

PVE Beauticians and hairdressing

\section{HGSE, IVE}

Higher General Secondary Education Senior General Secondary Education Pre-university Education

IVE Agriculture and the natural environment SIVE Agricultural

IVE Agriculture-A

IVE Agriculture-B

IVE Technical Laboratory

SIVE Laboratory

IVE Chemical laboratory

7

3

4

9

12

8

7

7
13

19

9

5
15

20

5

20

20

IVE Technical

SIVE Metalworking

SIVE Automobile technology

SIVE Electrical technology

SIVE Food technology

IVE Construction technology

IVE Civil engineering

IVE Metalworking

IVE Mechanical engineering

IVE Automobile technology

IVE Electrical technology

IVE Process technologies

IVE Textile and leather technology

IVE Transport and harbour

IVE Nursing and paramedical services

IVE Nursing and home care

IVE Medical assistant very low

very low

7

very low

very low

low

low

low

low

very low

very low

average

average

low

very low average

very low very low

high

low

very low

high

high

low

average

average

average

low

low

high

low

low

average

average

low

average

average

low 
Table 3.21 (continued)

Percentage of school-leavers unemployed for 4 months or longer on entering the labour market per field of study, 1994

\begin{tabular}{|c|c|c|}
\hline Type of education and field of study & $\%$ & qualitative charact. \\
\hline IVE Medical laboratory & 18 & average \\
\hline $\begin{array}{l}\text { IVE Commerce and administration } \\
\text { SIVE Retail } \\
\text { SIVE Administration } \\
\text { IVE Retail } \\
\text { IVE Administration } \\
\text { IVE Commerce } \\
\text { IVE Secretarial }\end{array}$ & $\begin{array}{l}17 \\
26 \\
10 \\
12 \\
16 \\
19\end{array}$ & $\begin{array}{l}\text { average } \\
\text { high } \\
\text { low } \\
\text { low } \\
\text { average } \\
\text { average }\end{array}$ \\
\hline IVE Legal and fiscal & 16 & average \\
\hline IVE Social and cultural & 21 & high \\
\hline $\begin{array}{l}\text { IVE Personal services } \\
\text { SIVE Community care } \\
\text { IVE Social services } \\
\text { IVE Community care } \\
\text { IVE Fashion and clothing } \\
\text { IVE Activities supervision }\end{array}$ & $\begin{array}{l}28 \\
21 \\
11 \\
23 \\
14\end{array}$ & $\begin{array}{l}\text { very high } \\
\text { high } \\
\text { low } \\
\text { high } \\
\text { average }\end{array}$ \\
\hline $\begin{array}{l}\text { IVE Hotel, catering and hairdressing } \\
\text { IVE Hotel and catering } \\
\text { IVE Building and food services maintenance } \\
\text { IVE Beauticians and hairdressing }\end{array}$ & $\begin{array}{l}12 \\
14 \\
19\end{array}$ & $\begin{array}{l}\text { low } \\
\text { average } \\
\text { average }\end{array}$ \\
\hline HVE & & \\
\hline $\begin{array}{l}\text { HVE Teacher training } \\
\text { HVE Primary school teacher } \\
\text { HVE Agricultural teacher } \\
\text { HVE Art and self-expression teacher } \\
\text { HVE Secondary school teacher }\end{array}$ & $\begin{array}{l}14 \\
11 \\
25 \\
26\end{array}$ & $\begin{array}{l}\text { average } \\
\text { low } \\
\text { high } \\
\text { high }\end{array}$ \\
\hline HVE Interpreter and translator & 23 & high \\
\hline HVE Agriculture & 23 & high \\
\hline HVE Technical laboratory & 26 & high \\
\hline $\begin{array}{l}\text { HVE Technical } \\
\text { HVE Construction and civil engineering } \\
\text { HVE Mechanical engineering } \\
\text { HVE Electronic technology }\end{array}$ & $\begin{array}{l}10 \\
27 \\
27\end{array}$ & $\begin{array}{l}\text { low } \\
\text { very high } \\
\text { very high }\end{array}$ \\
\hline HVE Transport and harbour & . & very low \\
\hline HVE Medical analysis & 25 & high \\
\hline $\begin{array}{l}\text { HVE Nursing and paramedical services } \\
\text { HVE Nursing } \\
\text { HVE Occupational and physiotherapy }\end{array}$ & $\begin{array}{l}12 \\
20\end{array}$ & $\begin{array}{l}\text { low } \\
\text { high }\end{array}$ \\
\hline
\end{tabular}


Table 3.21 (continued)

Percentage of school-leavers unemployed for 4 months or longer on entering the labour market per field of study, 1994

\begin{tabular}{|c|c|c|}
\hline Type of education and field of study & $\%$ & qualitative charact. \\
\hline $\begin{array}{l}\text { HVE Commerce and administration } \\
\text { HVE Business administration } \\
\text { HVE Accounting } \\
\text { HVE Commercial information science } \\
\text { HVE Tourism } \\
\text { HVE Commerce }\end{array}$ & $\begin{array}{r}14 \\
7 \\
24 \\
20 \\
18\end{array}$ & $\begin{array}{l}\text { average } \\
\text { very low } \\
\text { high } \\
\text { high } \\
\text { average }\end{array}$ \\
\hline HVE Business administration technology & 31 & very high \\
\hline HVE Legal and fiscal & 18 & average \\
\hline $\begin{array}{l}\text { HVE Social and cultural } \\
\text { HVE Welfare and social work } \\
\text { HVE Personnel management } \\
\text { HVE Journalism }\end{array}$ & $\begin{array}{l}18 \\
18 \\
20\end{array}$ & $\begin{array}{l}\text { average } \\
\text { average } \\
\text { high }\end{array}$ \\
\hline HVE Fine Arts & 36 & very high \\
\hline
\end{tabular}

Source: RUBS/HBO Monitor/ROA

- As a percentage of the school-leavers who are defined as in the labour force. 
Table 3.22

Percentage of school-leavers ${ }^{*}$ registered as unemployed per field of study, 1994

\begin{tabular}{|c|c|c|}
\hline Type of education and field of study & $\%$ & qualitative charact. \\
\hline LGSE, PVE & & \\
\hline Lower General Secondary Education & 14 & high \\
\hline PVE Agriculture & 8 & average \\
\hline $\begin{array}{l}\text { PVE Technical } \\
\text { PVE Construction trades } \\
\text { PVE Utilities installation } \\
\text { PVE Mechanical trades } \\
\text { PVE Automobile trades } \\
\text { PVE Electrical trades } \\
\text { PVE Printing trades } \\
\text { PVE Food trades } \\
\text { PVE Textile and leather trades }\end{array}$ & $\begin{array}{r}6 \\
5 \\
5 \\
5 \\
10 \\
4 \\
10 \\
11\end{array}$ & $\begin{array}{l}\text { low } \\
\text { low } \\
\text { low } \\
\text { low } \\
\text { average } \\
\text { very low } \\
\text { average } \\
\text { high }\end{array}$ \\
\hline $\begin{array}{l}\text { PVE Commerce and administration } \\
\text { PVE Office administration } \\
\text { PVE Retailing }\end{array}$ & $\begin{array}{l}10 \\
11\end{array}$ & $\begin{array}{l}\text { average } \\
\text { high }\end{array}$ \\
\hline $\begin{array}{l}\text { PVE Personal services } \\
\text { PVE Community care, hotel and catering } \\
\text { PVE Beauticians and hairdressing }\end{array}$ & $\begin{array}{l}9 \\
7\end{array}$ & $\begin{array}{l}\text { average } \\
\text { average }\end{array}$ \\
\hline HGSE, IVE & & \\
\hline $\begin{array}{l}\text { Higher General Secondary Education } \\
\text { Senior General Secondary Education } \\
\text { Pre-university Education }\end{array}$ & $\begin{array}{r}6 \\
13\end{array}$ & $\begin{array}{l}\text { low } \\
\text { high }\end{array}$ \\
\hline $\begin{array}{l}\text { IVE Agriculture and the natural environment } \\
\text { SIVE Agricultural } \\
\text { IVE Agriculture-A } \\
\text { IVE Agriculture-B }\end{array}$ & $\begin{array}{l}8 \\
2\end{array}$ & $\begin{array}{l}\text { average } \\
\text { very low } \\
\text { very low }\end{array}$ \\
\hline $\begin{array}{l}\text { IVE Technical Laboratory } \\
\text { SIVE Laboratory } \\
\text { IVE Chemical laboratory }\end{array}$ & $\begin{array}{r}14 \\
9\end{array}$ & $\begin{array}{l}\text { high } \\
\text { average }\end{array}$ \\
\hline $\begin{array}{l}\text { IVE Technical } \\
\text { SIVE Metalworking } \\
\text { SIVE Automobile technology } \\
\text { SIVE Electrical technology } \\
\text { SIVE Food technology } \\
\text { IVE Construction technology } \\
\text { IVE Civil engineering } \\
\text { IVE Metalworking } \\
\text { IVE Mechanical engineering } \\
\text { IVE Automobile technology } \\
\text { IVE Electrical technology } \\
\text { IVE Process technologies } \\
\text { IVE Textile and leather technology }\end{array}$ & $\begin{array}{r}8 \\
9 \\
16 \\
7 \\
5 \\
4 \\
8 \\
8 \\
5 \\
9 \\
15 \\
2\end{array}$ & $\begin{array}{l}\text { average } \\
\text { average } \\
\text { very high } \\
\text { average } \\
\text { low } \\
\text { very low } \\
\text { average } \\
\text { average } \\
\text { low } \\
\text { average } \\
\text { high } \\
\text { very low }\end{array}$ \\
\hline IVE Transport and harbour & 4 & very low \\
\hline $\begin{array}{l}\text { IVE Nursing and paramedical services } \\
\text { IVE Nursing and home care } \\
\text { IVE Medical assistant }\end{array}$ & $\begin{array}{l}5 \\
5\end{array}$ & $\begin{array}{l}\text { low } \\
\text { low }\end{array}$ \\
\hline
\end{tabular}


Table 3.22 (continued)

Percentage of school-leavers registered as unemployed per field of study, 1994

\begin{tabular}{|c|c|c|}
\hline Type of education and field of study & $\%$ & qualitative charact. \\
\hline IVE Medical laboratory & 7 & average \\
\hline $\begin{array}{l}\text { IVE Commerce and administration } \\
\text { SIVE Retail } \\
\text { SIVE Administration } \\
\text { IVE Retail } \\
\text { IVE Administration } \\
\text { IVE Commerce } \\
\text { IVE Secretarial }\end{array}$ & $\begin{array}{r}9 \\
10 \\
6 \\
7 \\
9 \\
5\end{array}$ & $\begin{array}{l}\text { average } \\
\text { average } \\
\text { low } \\
\text { average } \\
\text { average } \\
\text { low }\end{array}$ \\
\hline IVE Legal and fiscal & 7 & average \\
\hline IVE Social and cultural & 19 & very high \\
\hline $\begin{array}{l}\text { IVE Personal services } \\
\text { SIVE Community care } \\
\text { IVE Social services } \\
\text { IVE Community care } \\
\text { IVE Fashion and clothing } \\
\text { IVE Activities supervision }\end{array}$ & $\begin{array}{r}14 \\
8 \\
5 \\
9 \\
7\end{array}$ & $\begin{array}{l}\text { high } \\
\text { average } \\
\text { low } \\
\text { average } \\
\text { average }\end{array}$ \\
\hline $\begin{array}{l}\text { IVE Hotel, catering and hairdressing } \\
\text { IVE Hotel and catering } \\
\text { IVE Building and food services maintenance } \\
\text { IVE Beauticians and hairdressing }\end{array}$ & $\begin{array}{r}8 \\
13 \\
9\end{array}$ & $\begin{array}{l}\text { average } \\
\text { high } \\
\text { average }\end{array}$ \\
\hline HVE & & \\
\hline $\begin{array}{l}\text { HVE Teacher training } \\
\text { HVE Primary school teacher } \\
\text { HVE Agricultural teacher } \\
\text { HVE Art and self-expression teacher } \\
\text { HVE Secondary school teacher }\end{array}$ & $\begin{array}{r}6 \\
14 \\
10\end{array}$ & $\begin{array}{l}\text { low } \\
\text { very low } \\
\text { high } \\
\text { average }\end{array}$ \\
\hline HVE Interpreter and translator & 10 & average \\
\hline HVE Agriculture & 9 & average \\
\hline HVE Technical laboratory & 17 & very high \\
\hline $\begin{array}{l}\text { HVE Technical } \\
\text { HVE Construction and civil engineering } \\
\text { HVE Mechanical engineering } \\
\text { HVE Electronic technology }\end{array}$ & $\begin{array}{r}4 \\
13 \\
15\end{array}$ & $\begin{array}{l}\text { very low } \\
\text { high } \\
\text { high }\end{array}$ \\
\hline HVE Transport and harbour & 8 & average \\
\hline HVE Medical analysis & 9 & average \\
\hline $\begin{array}{l}\text { HVE Nursing and paramedical services } \\
\text { HVE Nursing } \\
\text { HVE Occupational and physiotherapy }\end{array}$ & $\begin{array}{r}4 \\
12\end{array}$ & $\begin{array}{l}\text { very low } \\
\text { high }\end{array}$ \\
\hline
\end{tabular}


Table 3.22 (continued)

Percentage of school-leavers registered as unemployed per field of study, 1994

\begin{tabular}{|c|c|c|}
\hline Type of education and field of study & $\%$ & qualitative charact. \\
\hline $\begin{array}{l}\text { HVE Commerce and administration } \\
\text { HVE Business administration } \\
\text { HVE Accounting } \\
\text { HVE Commercial information science } \\
\text { HVE Tourism } \\
\text { HVE Commerce }\end{array}$ & $\begin{array}{r}6 \\
2 \\
7 \\
15 \\
8\end{array}$ & $\begin{array}{l}\text { low } \\
\text { very low } \\
\text { average } \\
\text { high } \\
\text { average }\end{array}$ \\
\hline HVE Business administration technology & 17 & very high \\
\hline HVE Legal and fiscal & 9 & average \\
\hline $\begin{array}{l}\text { HVE Social and cultural } \\
\text { HVE Welfare and social work } \\
\text { HVE Personnel management } \\
\text { HVE Journalism }\end{array}$ & $\begin{array}{r}9 \\
10 \\
15\end{array}$ & $\begin{array}{l}\text { average } \\
\text { average } \\
\text { high }\end{array}$ \\
\hline HVE Fine Arts & 18 & very high \\
\hline
\end{tabular}

Source: RUBS/HBO Monitor/ROA

- As a percentage of the school-leavers who are defined as in the labour force. 
Table 3.23

Percentage of under-utilization per type of education, 1994

Type of education $\%$ qualitative charact.

Primary Education

Primary Education

LGSE, PVE

Lower General Secondary Education

PVE Agriculture

PVE Construction trades

PVE Utilities installation

PVE Mechanical trades

PVE Automobile trades

PVE Electrical trades

PVE Printing trades

PVE Food trades

PVE Textile and leather trades

PVE Transport and harbour

PVE Administration

PVE Commerce

PVE Community care, hotel and catering

PVE Security

HGSE, IVE

Higher General Secondary Education

IVE Agriculture and the natural environment

IVE Technical Laboratory

IVE Construction technology

IVE Civil engineering

IVE Metalworking

IVE Precision engineering

IVE Mechanical engineering

IVE Automobile technology

IVE Electrical technology

IVE Printing technology

IVE Food technology

IVE Process technologies

IVE Textile and leather technology

IVE Transport and harbour

IVE Nursing and paramedical services

IVE Medical laboratory

IVE Retail

IVE Administration

IVE Tourism and recreation

IVE Commerce

IVE Secretarial

IVE Legal and fiscal

IVE Social and cultura

IVE Community care

IVE Hotel, catering and hairdressing

IVE Police, fire and defense
average
average
average
average
average
average
average
high
high
very high
average
high
high
very high

average

average

average

average

high

average

average

average

low

high

high

very high

very high

high

low

very low

average

low

high

average

average

average

average

high

average

high 
Table 3.23 (continued)

Percentage of under-utilization per type of education, 1994

Type of education $\%$ qualitative charact.

HVE

HVE Teacher training

HVE Interpreter and translator

HVE Agriculture and environmental science

HVE Technical laboratory

HVE Construction and civil engineering

HVE Mechanical engineering

HVE Electronic and information technology

HVE Transport and harbour

HVE Medical laboratory

HVE Nursing and paramedical services

HVE Business administration

HVE Accounting

HVE Commercial information science

HVE Tourism and recreation

HVE Commerce

HVE Business administration technology

HVE Legal and fiscal

HVE Social and cultural

HVE Fine Arts

HVE Police, fire and defense

UE

UE Arts

UE Theology

UE Agriculture and environmental science

UE Mathematics and natural sciences

UE Construction and civil engineering

UE Mechanical engineering

UE Electrical engineering and information technology

UE Veterinary and medical sciences and dentistry

UE Pharmacy

UE Economics, econometrics and business administration

UE Management science

UE Information science

UE Law

UE Public administration

UE Social sciences

UE Fine Arts

low

average

average

low

very low

low

low

average

low

low

average

average

very low

very high

average

average

low

low

average

average

low

low

-

very low

-

low

low

average

Source: ROA

Determined on the basis of the function level of the occupational group. 
Table 3.24

Under-utilization ${ }^{*}$ of working school-leavers per field of study, 1994

\begin{tabular}{|c|c|c|}
\hline Type of education and field of study & $\%$ & qualitative charact. \\
\hline LGSE, PVE & & \\
\hline Lower General Secondary Education & 15 & low \\
\hline PVE Agriculture & 14 & low \\
\hline $\begin{array}{l}\text { PVE Technical } \\
\text { PVE Construction trades } \\
\text { PVE Utilities installation } \\
\text { PVE Mechanical trades } \\
\text { PVE Automobile trades } \\
\text { PVE Electrical trades } \\
\text { PVE Printing trades } \\
\text { PVE Food trades } \\
\text { PVE Textile and leather trades }\end{array}$ & $\begin{array}{r}9 \\
14 \\
10 \\
9 \\
. \\
4 \\
19\end{array}$ & $\begin{array}{l}\text { very low } \\
\text { average } \\
\text { low } \\
\text { low } \\
\text { very low } \\
\text { average } \\
\text { very low } \\
\text { average }\end{array}$ \\
\hline $\begin{array}{l}\text { PVE Commerce and administration } \\
\text { PVE Office administration } \\
\text { PVE Retailing }\end{array}$ & $\begin{array}{l}15 \\
16\end{array}$ & $\begin{array}{l}\text { low } \\
\text { low }\end{array}$ \\
\hline $\begin{array}{l}\text { PVE Personal services } \\
\text { PVE Community care, hotel and catering } \\
\text { PVE Beauticians and hairdressing }\end{array}$ & $\begin{array}{l}13 \\
15\end{array}$ & $\begin{array}{l}\text { low } \\
\text { low }\end{array}$ \\
\hline HGSE, IVE & & \\
\hline $\begin{array}{l}\text { Higher General Secondary Education } \\
\text { Senior General Secondary Education } \\
\text { Pre-university Education }\end{array}$ & . & $\begin{array}{l}\text { very high } \\
\text { very high }\end{array}$ \\
\hline $\begin{array}{l}\text { IVE Agriculture and the natural environment } \\
\text { SIVE Agricultural } \\
\text { IVE Agriculture-A } \\
\text { IVE Agriculture-B }\end{array}$ & 63 & $\begin{array}{l}\text { high } \\
\text { high } \\
\text { very high }\end{array}$ \\
\hline $\begin{array}{l}\text { IVE Technical Laboratory } \\
\text { SIVE Laboratory } \\
\text { IVE Chemical laboratory }\end{array}$ & $\begin{array}{l}61 \\
16\end{array}$ & $\begin{array}{l}\text { very high } \\
\text { low }\end{array}$ \\
\hline $\begin{array}{l}\text { IVE Technical } \\
\text { SIVE Metalworking } \\
\text { SIVE Automobile technology } \\
\text { SIVE Electrical technology } \\
\text { SIVE Food technology } \\
\text { IVE Construction technology } \\
\text { IVE Civil engineering } \\
\text { IVE Metalworking } \\
\text { IVE Mechanical engineering } \\
\text { IVE Automobile technology } \\
\text { IVE Electrical technology } \\
\text { IVE Process technologies } \\
\text { IVE Textile and leather technology }\end{array}$ & $\begin{array}{r}60 \\
45 \\
41 \\
20 \\
25 \\
8 \\
42 \\
38 \\
34 \\
34\end{array}$ & $\begin{array}{l}\text { very high } \\
\text { high } \\
\text { high } \\
\text { average } \\
\text { average } \\
\text { very low } \\
\text { high } \\
\text { high } \\
\text { high } \\
\text { average } \\
\text { high } \\
\text { average }\end{array}$ \\
\hline IVE Transport and harbour & 20 & average \\
\hline $\begin{array}{l}\text { IVE Nursing and paramedical services } \\
\text { IVE Nursing and home care } \\
\text { IVE Medical assistant }\end{array}$ & $\begin{array}{l}53 \\
49\end{array}$ & $\begin{array}{l}\text { high } \\
\text { high }\end{array}$ \\
\hline
\end{tabular}


Table 3.24 (continued)

Under-utilization of working school-leavers per field of study, 1994

\begin{tabular}{|c|c|c|}
\hline Type of education and field of study & $\%$ & qualitative charact. \\
\hline IVE Medical laboratory & 15 & low \\
\hline \multicolumn{3}{|l|}{ IVE Commerce and administration } \\
\hline SIVE Retail & 66 & very high \\
\hline SIVE Administration & 57 & very high \\
\hline IVE Retail & 42 & high \\
\hline IVE Administration & 22 & average \\
\hline IVE Commerce & 21 & average \\
\hline IVE Secretarial & 10 & low \\
\hline IVE Legal and fiscal & 21 & average \\
\hline IVE Social and cultural & 22 & average \\
\hline \multicolumn{3}{|l|}{ IVE Personal services } \\
\hline SIVE Community care & 68 & very high \\
\hline IVE Social services & 42 & high \\
\hline IVE Community care & 54 & high \\
\hline IVE Fashion and clothing & 63 & very high \\
\hline IVE Activities supervision & 32 & average \\
\hline \multicolumn{3}{|l|}{ IVE Hotel, catering and hairdressing } \\
\hline IVE Hotel and catering & 31 & average \\
\hline IVE Building and food services maintenance & 66 & very high \\
\hline IVE Beauticians and hairdressing & 61 & very high \\
\hline \multicolumn{3}{|l|}{ HVE } \\
\hline \multicolumn{3}{|l|}{ HVE Teacher training } \\
\hline HVE Primary school teacher & 5 & very low \\
\hline HVE Agricultural teacher & 20 & average \\
\hline HVE Art and self-expression teacher & 29 & average \\
\hline HVE Secondary school teacher & 27 & average \\
\hline HVE Interpreter and translator & 35 & high \\
\hline HVE Agriculture & 35 & high \\
\hline HVE Technical laboratory & 20 & average \\
\hline \multicolumn{3}{|l|}{ HVE Technical } \\
\hline HVE Construction and civil engineering & 9 & very low \\
\hline HVE Mechanical engineering & 23 & average \\
\hline HVE Electronic technology & 20 & average \\
\hline HVE Transport and harbour & 11 & low \\
\hline HVE Medical analysis & 21 & average \\
\hline \multicolumn{3}{|l|}{ HVE Nursing and paramedical services } \\
\hline HVE Nursing & 27 & average \\
\hline HVE Occupational and physiotherapy & 9 & very low \\
\hline
\end{tabular}


Table 3.24 (continued)

Under-utilization of working school-leavers per field of study, 1994

\begin{tabular}{lcl}
\hline Type of education and field of study & $\%$ & qualitative charact. \\
\hline HVE Commerce and administration & & \\
HVE Business administration & 21 & $\begin{array}{l}\text { average } \\
\text { very low }\end{array}$ \\
HVE Accounting & 4 & low \\
HVE Commercial information science & 12 & high \\
HVE Tourism & 56 & average \\
HVE Commerce & 28 & average \\
HVE Business administration technology & 21 & average \\
HVE Legal and fiscal & 22 & \\
HVE Social and cultural & & high \\
HVE Welfare and social work & & average \\
HVE Personnel management & 49 & average \\
HVE Journalism & 18 & average \\
HVE Fine Arts & 17 &
\end{tabular}

Source: RUBS/HBO Monitor/ROA

Determined on the basis of the educational level which, according to the school-leaver concerned, is required for the job which he or she has. 
Table 3.25

Percentage of working school-leavers with a job in the field in which they trained per field of study, 1994

Type of education and field of study $\%$ qualitative charact.

\section{LGSE, PVE}

Lower General Secondary Education

PVE Agriculture

PVE Technical

PVE Construction trades

PVE Utilities installation

PVE Mechanical trades

PVE Automobile trades

PVE Electrical trades

PVE Printing trades

PVE Food trades

PVE Textile and leather trades

PVE Commerce and administration

PVE Office administration

PVE Retailing

PVE Personal services

PVE Community care, hotel and catering

PVE Beauticians and hairdressing

HGSE, IVE

Higher General Secondary Education

Higher General Secondary Education

Pre-university Education

IVE Agriculture and the natural environment

SIVE Agricultural

IVE Agriculture-A

IVE Agriculture-B

IVE Technical Laboratory

SIVE Laboratory

IVE Chemical laboratory

IVE Technical

SIVE Metalworking

SIVE Automobile technology

SIVE Electrical technology

SIVE Food technology

IVE Construction technology

IVE Civil engineering

IVE Metalworking

IVE Mechanical engineering

IVE Automobile technology

IVE Electrical technology

IVE Process technologies

IVE Textile and leather technology

IVE Transport and harbour

IVE Nursing and paramedical services

IVE Nursing and home care

IVE Medical assistant very low

low

19

66

56

14

18

ery low average

very low

average

61

81

average

high

average

average

low

average

high

high

low

average

average

average

low

average

46

average

78

70 high

average 
Table 3.25 (continued)

Percentage of working school-leavers with a job in the field in which they trained per field of study, 1994

\begin{tabular}{|c|c|c|}
\hline Type of education and field of study & $\%$ & qualitative charact. \\
\hline IVE Medical laboratory & 77 & high \\
\hline $\begin{array}{l}\text { IVE Commerce and administration } \\
\text { SIVE Retail } \\
\text { SIVE Administration } \\
\text { IVE Retail } \\
\text { IVE Administration } \\
\text { IVE Commerce } \\
\text { IVE Secretarial }\end{array}$ & $\begin{array}{l}11 \\
39 \\
31 \\
44 \\
32 \\
52\end{array}$ & $\begin{array}{l}\text { very low } \\
\text { low } \\
\text { low } \\
\text { low } \\
\text { low } \\
\text { average }\end{array}$ \\
\hline IVE Legal and fiscal & 15 & very low \\
\hline IVE Social and cultural & 46 & average \\
\hline $\begin{array}{l}\text { IVE Personal services } \\
\text { SIVE Community care } \\
\text { IVE Social services } \\
\text { IVE Community care } \\
\text { IVE Fashion and clothing } \\
\text { IVE Activities supervision }\end{array}$ & $\begin{array}{l}27 \\
58 \\
67 \\
25 \\
73\end{array}$ & $\begin{array}{l}\text { low } \\
\text { average } \\
\text { average } \\
\text { very low } \\
\text { high }\end{array}$ \\
\hline $\begin{array}{l}\text { IVE Hotel, catering and hairdressing } \\
\text { IVE Hotel and catering } \\
\text { IVE Building and food services maintenance } \\
\text { IVE Beauticians and hairdressing }\end{array}$ & $\begin{array}{l}52 \\
32 \\
59\end{array}$ & $\begin{array}{l}\text { average } \\
\text { low } \\
\text { average }\end{array}$ \\
\hline HVE & & \\
\hline $\begin{array}{l}\text { HVE Teacher training } \\
\text { HVE Primary school teacher } \\
\text { HVE Agricultural teacher } \\
\text { HVE Art and self-expression teacher } \\
\text { HVE Secondary school teacher }\end{array}$ & $\begin{array}{l}91 \\
92 \\
71 \\
74\end{array}$ & $\begin{array}{l}\text { very high } \\
\text { very high } \\
\text { average } \\
\text { high }\end{array}$ \\
\hline HVE Interpreter and translator & 63 & average \\
\hline HVE Agriculture & 75 & high \\
\hline HVE Technical laboratory & 86 & high \\
\hline $\begin{array}{l}\text { HVE Technical } \\
\text { HVE Construction and civil engineering } \\
\text { HVE Mechanical engineering } \\
\text { HVE Electronic technology }\end{array}$ & $\begin{array}{l}93 \\
80 \\
83\end{array}$ & $\begin{array}{l}\text { very high } \\
\text { high } \\
\text { high }\end{array}$ \\
\hline HVE Transport and harbour & 91 & very high \\
\hline HVE Medical analysis & 85 & high \\
\hline $\begin{array}{l}\text { HVE Nursing and paramedical services } \\
\text { HVE Nursing } \\
\text { HVE Occupational and physiotherapy }\end{array}$ & $\begin{array}{l}94 \\
94\end{array}$ & $\begin{array}{l}\text { very high } \\
\text { very high }\end{array}$ \\
\hline
\end{tabular}


Table 3.25 (continued)

Percentage of working school-leavers with a job in the field in which they trained per field of study, 1994

\begin{tabular}{lll}
\hline Type of education and field of study & $\%$ & qualitative charact. \\
\hline HVE Commerce and administration & & \\
HVE Business administration & 79 & high \\
HVE Accounting & 96 & very high \\
HVE Commercial information science & 84 & high \\
HVE Tourism & 51 & average \\
HVE Commerce & 59 & average \\
HVE Business administration technology & 70 & average \\
HVE Legal and fiscal & & average \\
HVE Social and cultural & 66 & \\
HVE Welfare and social work & & high \\
HVE Personnel management & 85 & high \\
HVE Journalism & 78 & high \\
HVE Fine Arts & 80 & average \\
\hline
\end{tabular}

Source: RUBS/HBO Monitor/ROA 
Table 3.26

Expected flow of school-leavers entering the labour market per type of education, 1995-2000

\begin{tabular}{|c|c|c|c|c|}
\hline Type of education & number & $\begin{array}{r}\text { total } \\
\%\end{array}$ & $\begin{array}{l}\text { average } \\
\text { annual } \%\end{array}$ & $\begin{array}{l}\text { qualitative } \\
\text { charact. }\end{array}$ \\
\hline
\end{tabular}

\section{Primary Education}

Primary Education

$\begin{array}{llll}46,900 & 9 & 1.8 \quad \text { low }\end{array}$

\section{LGSE, PVE}

Lower General Secondary Education

PVE Agriculture

PVE Construction trades

6,600

PVE Utilities installation

1.8

low

PVE Mechanical trades

PVE Automobile trades

PVE Electrical trades

PVE Printing trades

PVE Food trades

PVE Textile and leather trades

PVE Transport and harbour

PVE Administration

PVE Commerce

PVE Community care, hotel and catering

PVE Security

24,500
6,600
14,200
1,500
14,800
7,100
1,300
1,100
5,400
5,500
2,200
9,000
5,000
13,900
6,000

$\begin{array}{rll}6 & 1.2 & \text { low } \\ 9 & 1.7 & \text { low } \\ 10 & 2.0 & \text { low } \\ 16 & 3.1 & \text { average } \\ 11 & 2.1 & \text { low } \\ 14 & 2.7 & \text { low } \\ 2 & 0.4 & \text { very low } \\ 15 & 2.8 & \text { average } \\ 26 & 4.8 & \text { average } \\ 23 & 4.3 & \text { average } \\ 6 & 1.2 & \text { low } \\ 15 & 2.7 & \text { average } \\ 16 & 3.1 & \text { average } \\ 7 & 1.3 & \text { low } \\ 58 & 9.6 & \text { very high }\end{array}$

\section{HGSE, IVE}

Higher General Secondary Education

IVE Technical Laboratory

IVE Construction technology

27,600

IVE Civil engineering

5,000

IVE Metalworking

12,000

1,700

IVE Precision engineering

IVE Mechanical engineering

18,400

IVE Automobile technology

20,600

IVE Electrical technology

IVE Printing technology

IVE Food technology

29,000

5,900

7,900

1,900

IVE Process technologies

6,400

VE Textile and leather technology

IVE Transport and harbour

IVE Nursing and paramedical services

IVE Medical laboratory

3,700

IVE Retail

IVE Administration

89,500

26,800

IVE Tourism and recreation

4,900

8,500

20,800

VE Secretaria

IVE Legal and fiscal

IVE Social and cultural

IVE Community care

1,800
18,900

18,900

8,500

IVE Hotel, catering and hairdressing

8,500
17,300

$\begin{array}{rll}28 & 5.1 & \text { average } \\ 17 & 3.1 & \text { average } \\ 27 & 4.9 & \text { average } \\ 17 & 3.1 & \text { average } \\ 23 & 4.3 & \text { average } \\ 21 & 3.8 & \text { average } \\ 11 & 2.1 & \text { low } \\ 20 & 3.8 & \text { average } \\ 34 & 6.1 & \text { high } \\ 20 & 3.7 & \text { average } \\ 16 & 3.0 & \text { average } \\ 19 & 3.5 & \text { average } \\ 11 & 2.2 & \text { low } \\ 18 & 3.3 & \text { average } \\ 18 & 3.4 & \text { average } \\ 25 & 4.5 & \text { average } \\ 13 & 2.4 & \text { low } \\ 28 & 5.0 & \text { average } \\ 29 & 5.2 & \text { high } \\ 32 & 5.7 & \text { high } \\ 24 & 4.4 & \text { average } \\ 22 & 4.0 & \text { average } \\ 4 & 0.7 & \text { very low } \\ 34 & 6.0 & \text { high } \\ 29 & 5.2 & \text { high } \\ 14 & 2.6 & \text { low } \\ 22 & 4.0 & \text { average }\end{array}$


Table 3.26 (continued)

Expected flow of school-leavers entering the labour market per type of education, 1995-2000

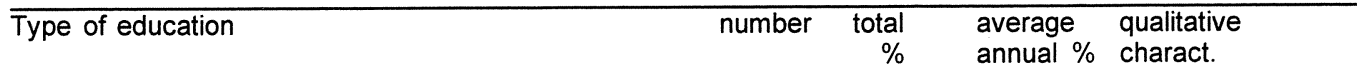

HVE

HVE Teacher training

HVE Interpreter and translator

HVE Agriculture and environmental science

HVE Technical laboratory

HVE Construction and civil engineering

HVE Mechanical engineering

HVE Electronic and information technology

HVE Transport and harbour

HVE Medical laboratory

HVE Nursing and paramedical services

HVE Business administration

HVE Accounting

HVE Commercial information science

HVE Tourism and recreation

HVE Commerce

HVE Business administration technology

HVE Legal and fiscal

HVE Social and cultural

HVE Fine Arts

HVE Police, fire and defense

$\begin{array}{rrr}39,900 & 15 & 2.9 \\ 1,400 & 16 & 3.0 \\ 6,900 & 35 & 6.2 \\ 4,700 & 17 & 3.2 \\ 4,300 & 12 & 2.2 \\ 9,800 & 32 & 5.8 \\ 13,700 & 32 & 5.8 \\ 1,300 & 5 & 0.9 \\ 2,600 & 12 & 2.3 \\ 20,100 & 24 & 4.4 \\ 9,200 & 41 & 7.2 \\ 2,500 & 9 & 1.7 \\ 4,900 & 17 & 3.2 \\ 1,700 & 22 & 4.0 \\ 12,300 & 60 & 9.8 \\ 6,500 & 51 & 8.6 \\ 4,300 & 17 & 3.1 \\ 31,400 & 27 & 4.9 \\ 7,200 & 15 & 2.9 \\ 2,200 & 23 & 4.3\end{array}$

average

average

high

average

low

high

high

low

low

average

very high

low

average

average

very high

very high

average

average

average

average

UE

UE Arts

UE Theology

36

$600 \quad 12$

3,600

8,700

2,400

UE Mathematics and natural sciences

4,100

UE Mechanical engineering

4,800

UE Electrical engineering and information technology

7,700

UE Veterinary and medical sciences and dentistry

7,700

UE Pharmacy

$\begin{array}{lr}\text { UE Economics, econometrics and business admin. } & 17,200 \\ \text { UE Management science } & 5,700\end{array}$

UE Management science

5,700

1,800

UE Law

2,600

UE Public administration

UE Social sciences

2,600

4,200

$\begin{array}{ll}6.3 & \text { high } \\ 2.3 & \text { low } \\ 5.2 & \text { high } \\ 3.8 & \text { average } \\ 2.5 & \text { low } \\ 8.1 & \text { very high } \\ 6.2 & \text { high } \\ 2.7 & \text { average } \\ 5.3 & \text { high } \\ 6.9 & \text { very high } \\ 9.4 & \text { very high } \\ 7.5 & \text { very high } \\ 6.9 & \text { very high } \\ 4.6 & \text { average } \\ 5.8 & \text { high } \\ 8.1 & \text { very high }\end{array}$

Source: ROA 
Table 3.27

Expected expansion demand per type of education, 1995-2000

\begin{tabular}{|c|c|c|c|c|}
\hline Type of education & number & $\begin{array}{r}\text { total } \\
\%\end{array}$ & $\begin{array}{l}\text { average } \\
\text { annual } \%\end{array}$ & $\begin{array}{l}\text { qualitative } \\
\text { charact. }\end{array}$ \\
\hline
\end{tabular}

Primary Education

Primary Education

$\begin{array}{llll}-66,300 & -13 & -2.8 & \text { very low }\end{array}$

LGSE, PVE

Lower General Secondary Education

$\begin{array}{rrrl}-18,400 & -5 & -0.9 & \text { low } \\ -7,100 & -9 & -1.9 & \text { very low } \\ -8,300 & -6 & -1.2 & \text { low } \\ -500 & -6 & -1.1 & \text { low } \\ -7,800 & -6 & -1.2 & \text { low } \\ -2,700 & -5 & -1.1 & \text { low } \\ -2,900 & -5 & -1.0 & \text { low } \\ -200 & -4 & -0.7 & \text { low } \\ -700 & -4 & -0.7 & \text { low } \\ -1,100 & -5 & -0.9 & \text { low } \\ -900 & -3 & -0.5 & \text { low } \\ -3,800 & -6 & -1.3 & \text { low } \\ -500 & -2 & -0.3 & \text { low } \\ -6,400 & -3 & -0.6 & \text { low } \\ 3,200 & 31 & 5.5 & \text { very high }\end{array}$

PVE Agriculture

PVE Construction trades

PVE Utilities installation

PVE Mechanical trades

PVE Automobile trades

$-66,300$

$-13$

very low

PVE Electrical trades

PVE Printing trades

PVE Food trades

PVE Textile and leather trades

PVE Transport and harbour

PVE Administration

PVE Commerce

PVE Community care, hotel and catering

PVE Security

very high

HGSE, IVE

Higher General Secondary Education

20,700

IVE Agriculture and the natural environment

$-2,100$

IVE Technical Laboratory

1,200

IVE Construction technology

5,200

IVE Civil engineering

1,200

IVE Metalworking

2,300

IVE Precision engineering

IVE Mechanical engineering

900

5,000

IVE Automobile technology

2,100

IVE Electrical technology

IVE Printing technology

8,700

2,200

IVE Food technology

IVE Process technologies

IVE Textile and leather technology

IVE Transport and harbour

IVE Nursing and paramedical services

2,000

900

1,600

2,600

16,400

IVE Medical laboratory

2,900

IVE Retail

IVE Administration

IVE Tourism and recreation

2,100

2,900

300

2,100

700

$-400$

IVE Secretarial

IVE Legal and fiscal

800

IVE Social and cultural

IVE Community care

9,100

IVE Hotel, catering and hairdressing

1,800

IVE Police, fire and defense

13,500

$\begin{array}{rr}7 & 1.3 \\ -2 & -0.3 \\ 9 & 1.7 \\ 3 & 0.6 \\ 6 & 1.1 \\ 4 & 0.8 \\ 6 & 1.2 \\ 6 & 1.1 \\ 3 & 0.7 \\ 6 & 1.2 \\ 6 & 1.2 \\ 5 & 1.0 \\ 5 & 1.0 \\ 4 & 0.9 \\ 6 & 1.1 \\ 9 & 1.7 \\ 10 & 2.0 \\ 7 & 1.3 \\ 3 & 0.6 \\ 2 & 0.4 \\ 6 & 1.2 \\ 1 & 0.1 \\ -1 & -0.2 \\ 2 & 0.3 \\ 4 & 0.8 \\ 3 & 0.6 \\ 17 & 3.1\end{array}$

average
low
average
low
average
average
average
average
low
average
average
average
average
average
average
average
average
average
low
low
average
low
low
low
average
low
high 
Table 3.27 (continued)

Expected expansion demand per type of education, 1995-2000

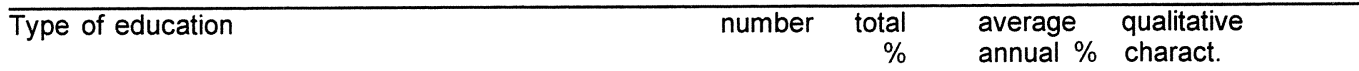

HVE

HVE Teacher training

HVE Interpreter and translator

HVE Agriculture and environmental science

HVE Technical laboratory

HVE Construction and civil engineering

HVE Mechanical engineering

HVE Electronic and information technology

HVE Transport and harbour

HVE Medical laboratory

HVE Nursing and paramedical services

HVE Business administration

HVE Accounting

HVE Commercial information science

HVE Tourism and recreation

HVE Commerce

HVE Business administration technology

HVE Legal and fiscal

HVE Social and cultural

HVE Fine Arts

HVE Police, fire and defense

$\begin{array}{rrrl}18,500 & 7 & 1.4 & \text { average } \\ 700 & 9 & 1.7 & \text { average } \\ 2,700 & 14 & 2.7 & \text { high } \\ 6,000 & 22 & 4.0 & \text { high } \\ 5,300 & 15 & 2.7 & \text { high } \\ 5,100 & 17 & 3.2 & \text { high } \\ 11,200 & 27 & 4.8 & \text { very high } \\ 4,300 & 15 & 2.9 & \text { high } \\ 3,400 & 16 & 2.9 & \text { high } \\ 14,400 & 17 & 3.2 & \text { high } \\ 3,900 & 18 & 3.3 & \text { high } \\ 7,000 & 25 & 4.5 & \text { very high } \\ 10,400 & 36 & 6.3 & \text { very high } \\ 500 & 7 & 1.4 & \text { average } \\ 3,800 & 19 & 3.5 & \text { high } \\ 2,800 & 22 & 4.0 & \text { high } \\ 1,900 & 7 & 1.4 & \text { average } \\ 14,100 & 12 & 2.3 & \text { average } \\ 7,300 & 15 & 2.9 & \text { high } \\ 200 & 2 & 0.5 & \text { low }\end{array}$

UE

UE Arts

UE Theology

$\begin{array}{ll}17 & 3.1\end{array}$

700

2,100

9,400

UE Mathematics and natural sciences

3,700

UE Construction and civil engineering

UE Mechanical engineering

$\begin{array}{ll}\text { UE Electrical engineering and information technology } & 4,200 \\ \text { UE Veterinary and medical sciences and dentistry } & 8,800\end{array}$

UE Veterinary and medical sciences and dentistry

8,800

UE Pharmacy

14,900

UE Management science $\quad 3,200$

UE Information science

3,200
1,500

4,000

UE Law

2,400

UE Public administration

UE Social sciences

2,400
14,800

UE Fine Arts

$\begin{array}{rll}13 & 2.5 & \text { average } \\ 17 & 3.2 & \text { high } \\ 22 & 4.1 & \text { high } \\ 20 & 3.7 & \text { high } \\ 22 & 4.0 & \text { high } \\ 31 & 5.5 & \text { very high } \\ 16 & 3.1 & \text { high } \\ 15 & 2.8 & \text { high } \\ 34 & 6.0 & \text { very high } \\ 32 & 5.7 & \text { very high } \\ 34 & 6.1 & \text { very high } \\ 8 & 1.6 & \text { average } \\ 24 & 4.4 & \text { very high } \\ 18 & 3.4 & \text { high } \\ 10 & 2.0 & \text { average }\end{array}$

Source: ROA 
Table 3.28

Expected replacement demand per type of education, 1995-2000

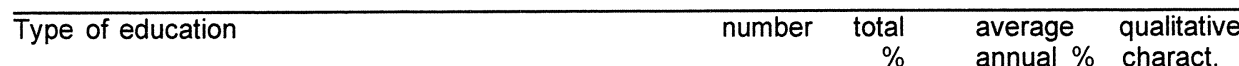

\section{Primary Education}

Primary Education

68,900

14

2.6

average

LGSE, PVE

Lower General Secondary Education

$\begin{array}{rrrl}55,800 & 14 & 2.6 & \text { average } \\ 11,000 & 14 & 2.7 & \text { average } \\ 17,300 & 13 & 2.4 & \text { average } \\ 1,200 & 13 & 2.4 & \text { average } \\ 21,100 & 15 & 2.9 & \text { average } \\ 5,300 & 11 & 2.1 & \text { low } \\ 7,000 & 12 & 2.2 & \text { low } \\ 800 & 11 & 2.1 & \text { low } \\ 1,700 & 9 & 1.7 & \text { very low } \\ 6,900 & 29 & 5.2 & \text { very high } \\ 6,200 & 17 & 3.2 & \text { high } \\ 5,800 & 9 & 1.8 & \text { very low } \\ 1,500 & 5 & 0.9 & \text { very low } \\ 39,100 & 19 & 3.6 & \text { high } \\ 1,100 & 11 & 2.1 & \text { low }\end{array}$

PVE Construction trades

$\begin{array}{lr}\text { Education } & 55,800 \\ & 11,000 \\ & 17,300 \\ & 1,200 \\ & 21,100 \\ & 5,300 \\ & 7,000 \\ 800 \\ \text { ades } & 1,700 \\ & 6,900 \\ & 6,200 \\ \text { ratering } & 5,800 \\ \text { and catering } & 1,500 \\ & 39,100 \\ & 1,100\end{array}$

33,000

19,100

1,900

26,800

IVE Agriculture and the natural environment

2,600

IVE Construction technology

9,400

IVE Metalworking

3,100

IVE Precision engineering

IVE Mechanical engineering

12,300

IVE Automobile technology

6,700

IVE Electrical technology

IVE Printing technology

18,300

6,100

IVE Food technology

IVE Process technologies

5,900

2,000

7,300

VE Textile and leather technology

IVE Transport and harbour

IVE Nursing and paramedical services

8,900

34,300

IVE Medical laboratory

4,400

IVE Retail

IVE Administration

64,000

13,500

700

3,500

11,400

IVE Commerce

8,300

IVE Legal and fiscal

6,700

IVE Social and cultural

IVE Community care

IVE Hotel, catering and hairdressing

31,500

7,800

IVE Police, fire and defense

12,000

$\begin{array}{rll}11 & 2.0 & \text { low } \\ 14 & 2.6 & \text { average } \\ 14 & 2.6 & \text { average } \\ 16 & 3.0 & \text { average } \\ 12 & 2.3 & \text { low } \\ 16 & 3.0 & \text { average } \\ 20 & 3.7 & \text { very high } \\ 14 & 2.6 & \text { average } \\ 11 & 2.1 & \text { low } \\ 13 & 2.4 & \text { average } \\ 16 & 3.0 & \text { average } \\ 14 & 2.7 & \text { average } \\ 12 & 2.3 & \text { low } \\ 20 & 3.7 & \text { very high } \\ 19 & 3.6 & \text { high } \\ 19 & 3.5 & \text { high } \\ 15 & 2.9 & \text { average } \\ 20 & 3.7 & \text { very high } \\ 15 & 2.8 & \text { average } \\ 4 & 0.9 & \text { very low } \\ 10 & 1.9 & \text { low } \\ 12 & 2.3 & \text { low } \\ 17 & 3.2 & \text { high } \\ 12 & 2.3 & \text { low } \\ 14 & 2.7 & \text { average } \\ 13 & 2.4 & \text { average } \\ 15 & 2.8 & \text { average }\end{array}$


Table 3.28 (continued)

Expected replacement demand per type of education, 1995-2000

Type of education $\quad$ number total $\begin{gathered}\text { average qualitative } \\ \text { annual } \%\end{gathered}$

HVE

HVE Teacher training

$\begin{array}{llll}50,900 & 20 & 3.7 & \text { very high }\end{array}$

HVE Interpreter and translator

$\begin{array}{lll}1,300 & 15 & 2.9\end{array}$

HVE Agriculture and environmental science

1,300

2,300

2.3

HVE Technical laboratory

$4,600 \quad 17$

$5,700 \quad 16$

HVE Construction and civil engineering

5,100

4,600

HVE Electronic and information technology

5,400

HVE Transport and harbour

$2,300 \quad 11$

HVE Medical laboratory

13,300

HVE Nursing and paramedical services

2,300

$5,500 \quad 20$

$2,900 \quad 10$

HVE Accounting

400
1,900

HVE Commercial information science

HVE Tourism and recreation

1,200

HVE Business administration technology

5,000

HVE Legal and fiscal

HVE Social and cultural

18,300

7,200

HVE Police, fire and defense

1,600

average

low

high

average

high

low

low

average

low

very high

low

very low

very low

very low

very high

average

average

high

\section{UE}

$\begin{array}{lrrrl}\text { UE Arts } & 5,900 & 14 & 2.6 & \text { average } \\ \text { UE Theology } & 1,700 & 31 & 5.6 & \text { very high } \\ \text { UE Agriculture and environmental science } & 1,200 & 10 & 1.9 & \text { low } \\ \text { UE Mathematics and natural sciences } & 8,200 & 19 & 3.6 & \text { high } \\ \text { UE Construction and civil engineering } & 3,500 & 19 & 3.5 & \text { high } \\ \text { UE Mechanical engineering } & 1,600 & 18 & 3.4 & \text { high } \\ \text { UE Electrical engineering and information technology } & 2,400 & 17 & 3.2 & \text { high } \\ \text { UE Veterinary and medical sciences and dentistry } & 11,900 & 22 & 4.1 & \text { very high } \\ \text { UE Pharmacy } & 700 & 15 & 2.7 & \text { average } \\ \text { UE Economics, econometrics and business admin. } & 7,700 & 18 & 3.3 & \text { high } \\ \text { UE Management science } & 1,500 & 15 & 2.8 & \text { average } \\ \text { UE Information science } & 500 & 11 & 2.2 & \text { low } \\ \text { UE Law } & 7,300 & 15 & 2.9 & \text { average } \\ \text { UE Public administration } & 1,300 & 13 & 2.4 & \text { average } \\ \text { UE Social sciences } & 14,300 & 18 & 3.3 & \text { high } \\ \text { UE Fine Arts } & 1,600 & 18 & 3.3 & \text { high }\end{array}$

Source: ROA 


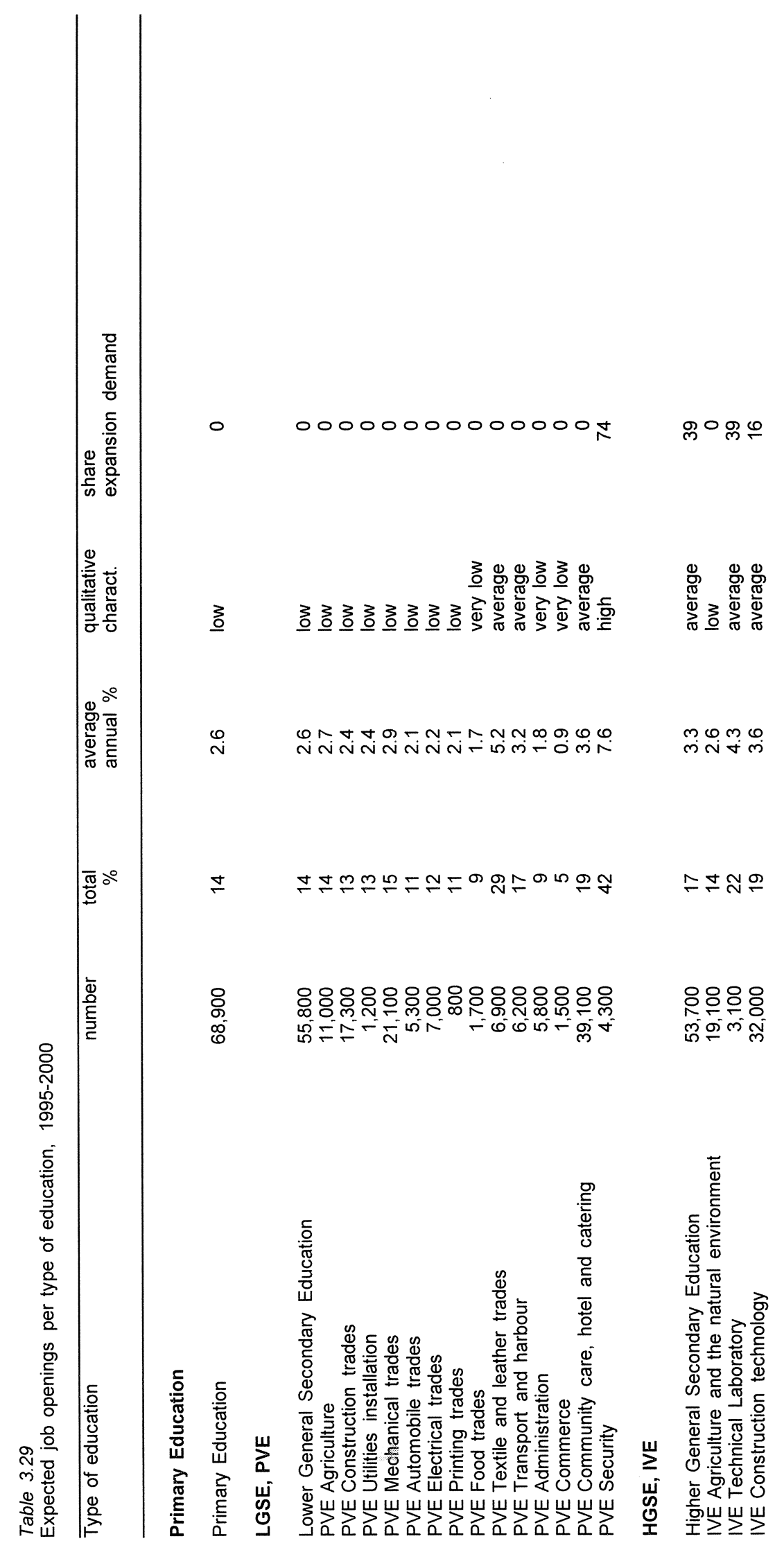




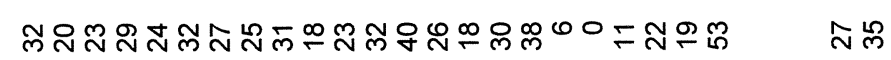

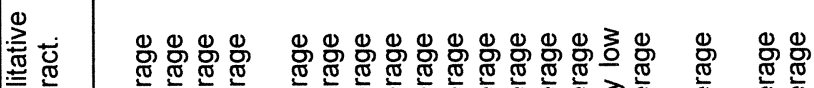

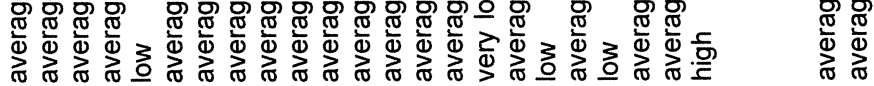

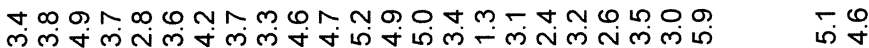




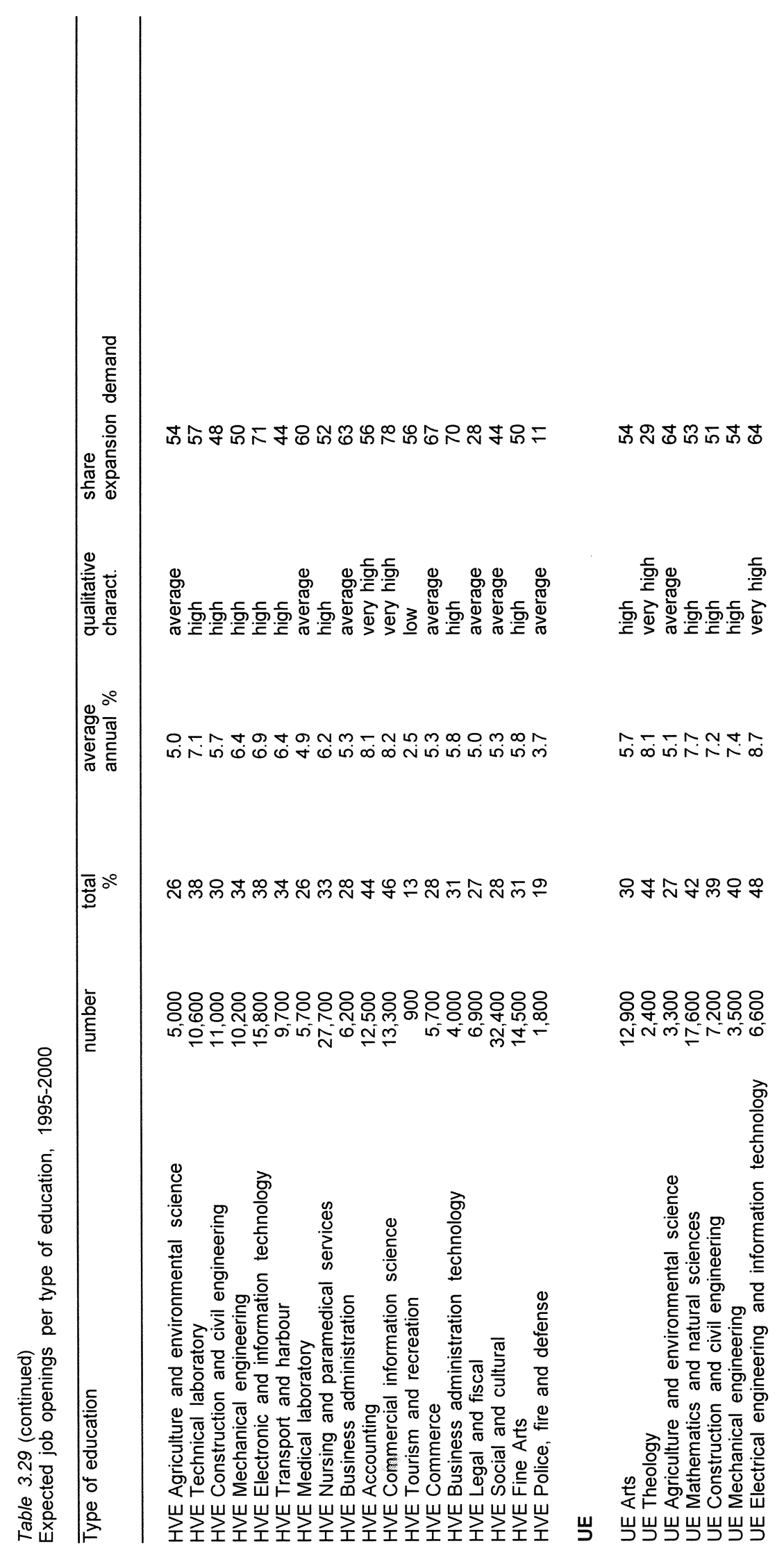




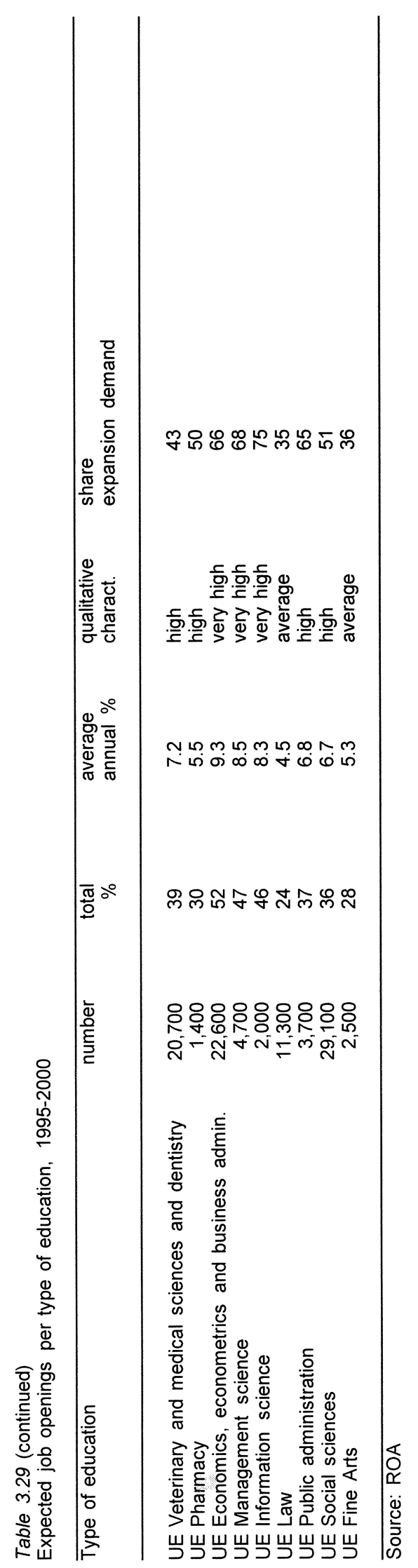


Table 3.30

Indicator of the future labour market situation (IFL) and Indicator of future risks of labour recruitment problems (IFRL) by type of education, in 2000

\begin{tabular}{|c|c|c|c|}
\hline Type of education & IFL & $\begin{array}{l}\text { qualitative charact. } \text { IFRL } \\
\text { labour market } \\
\text { situation }\end{array}$ & $\begin{array}{l}\text { qualitative charact. } \\
\text { recruitment } \\
\text { problems }\end{array}$ \\
\hline
\end{tabular}

\section{Primary Education}

Primary Education

LGSE, PVE

Lower General Secondary Education

PVE Agriculture

PVE Construction trades

PVE Utilities installation

PVE Mechanical trades

PVE Automobile trades

PVE Electrical trades

PVE Printing trades

PVE Food trades

PVE Textile and leather trades

PVE Transport and harbour

PVE Administration

PVE Commerce

PVE Community care, hotel and catering

PVE Security

HGSE, IVE

Higher General Secondary Education

IVE Agriculture and the natural environment

IVE Technical Laboratory

IVE Construction technology

IVE Civil engineering

IVE Metalworking

IVE Precision engineering

IVE Mechanical engineering

IVE Automobile technology

IVE Electrical technology

IVE Printing technology

IVE Food technology

IVE Process technologies

moderate

$\begin{array}{llll}1.01 & \text { reasonable } & 1.05 & \text { very low } \\ 1.07 & \text { moderate } & 1.17 & \text { very low } \\ 1.07 & \text { moderate } & 1.13 & \text { very low } \\ 1.13 & \text { moderate } & 1.20 & \text { very low } \\ 1.04 & \text { reasonable } & 1.09 & \text { very low } \\ 1.11 & \text { moderate } & 1.17 & \text { very low } \\ 1.01 & \text { reasonable } & 1.05 & \text { very low } \\ 1.07 & \text { moderate } & 1.11 & \text { very low } \\ 1.29 & \text { bad } & 1.34 & \text { very low } \\ 1.07 & \text { moderate } & 1.11 & \text { very low } \\ 0.97 & \text { good } & 0.99 & \text { fairly high } \\ 1.14 & \text { moderate } & 1.21 & \text { very low } \\ 1.22 & \text { bad } & 1.20 & \text { very low } \\ 0.99 & \text { good } & 1.02 & \text { low } \\ 1.06 & \text { moderate } & 1.06 & \text { very low }\end{array}$

VE Textile and leather technology

IVE Transport and harbour

IVE Nursing and paramedical services

IVE Medical laboratory

IVE Retail

IVE Administration

IVE Tourism and recreation

IVE Commerce

IVE Secretarial

IVE Legal and fiscal

IVE Social and cultural

IVE Community care

IVE Hotel, catering and hairdressing

IVE Police, fire and defense

1.13

1.11

1.06

1.03

1.07

1.07

0.93

1.06

1.22

1.06

0.99

1.06

1.03

1.00

0.98

1.00

0.94

1.05

1.12

1.26

1.10

1.11

0.91

1.20

1.14

1.07

0.95 moderate

moderate

moderate

reasonable

moderate

moderate

good

moderate

moderate

good

moderate

reasonable

good

good

good

good

reasonable

moderate

moderate

moderate

good

bad

moderate

moderate

good
1.13 very low

1.12 very low

1.06 very low

1.03 low

1.07 very low

1.07 very low

0.93 high

1.06 very low

1.22 very low

1.06 very low

0.99 fairly high

1.06 very low

1.03 low

1.00 fairly high

0.98 fairly high

1.00 fairly high

0.94 high

1.05 very low

1.12 very low

1.26 very low

1.10 very low

1.11 very low

0.91 high

1.20 very low

1.14 very low

1.07 very low

0.95 high 
Table 3.30 (continued)

Indicator of the future labour market situation (IFL) and Indicator of future risks of labour recruitment problems (IFRL) by type of education, in 2000

\begin{tabular}{llll}
\hline Type of education & IFL & $\begin{array}{l}\text { qualitative charact. } \\
\text { labour market } \\
\text { situation }\end{array}$ & IFRL qualitative charact. \\
& & $\begin{array}{l}\text { recruitment } \\
\text { problems }\end{array}$
\end{tabular}

HVE

HVE Teacher training

HVE Interpreter and translator

HVE Agriculture and environmental science

HVE Technical laboratory

HVE Construction and civil engineering

HVE Mechanical engineering

HVE Electronic and information technology

HVE Transport and harbour

HVE Medical laboratory

HVE Nursing and paramedical services $\quad 0.94$

HVE Business administration

HVE Accounting

HVE Commercial information science $\quad 0.77$

HVE Tourism and recreation

HVE Commerce

HVE Business administration technology

HVE Legal and fiscal

HVE Social and cultural

HVE Fine Arts

HVE Police, fire and defense

$\begin{array}{llll}0.93 & \text { good } & 0.93 & \text { high } \\ 0.95 & \text { good } & 0.95 & \text { high } \\ 1.07 & \text { moderate } & 1.07 & \text { very low } \\ 0.85 & \text { good } & 0.85 & \text { high } \\ 0.83 & \text { good } & 0.83 & \text { high } \\ 0.98 & \text { good } & 0.98 & \text { fairly high } \\ 0.94 & \text { good } & 0.94 & \text { high } \\ 0.79 & \text { good } & 0.79 & \text { high } \\ 0.91 & \text { good } & 0.91 & \text { high } \\ 0.94 & \text { good } & 0.94 & \text { high } \\ 1.08 & \text { moderate } & 1.08 & \text { very low } \\ 0.73 & \text { good } & 0.73 & \text { high } \\ 0.77 & \text { good } & 0.77 & \text { high } \\ 1.10 & \text { moderate } & 1.10 & \text { very low } \\ 1.22 & \text { bad } & 1.22 & \text { very low } \\ 1.13 & \text { moderate } & 1.13 & \text { very low } \\ 0.92 & \text { good } & 0.92 & \text { high } \\ 0.99 & \text { good } & 0.99 & \text { fairly high } \\ 0.91 & \text { good } & 0.91 & \text { high } \\ 0.99 & \text { good } & 0.99 & \text { fairly high }\end{array}$

UE

UE Arts

$\begin{array}{ll}1.07 & \text { moderate } \\ 0.79 & \text { good } \\ 1.00 & \text { good } \\ 0.83 & \text { good } \\ 0.76 & \text { good } \\ 1.00 & \text { good } \\ 0.86 & \text { good } \\ 0.83 & \text { good } \\ 0.98 & \text { good } \\ 0.88 & \text { good } \\ 1.03 & \text { reasonable } \\ 0.93 & \text { good } \\ 1.10 & \text { moderate } \\ 0.88 & \text { good } \\ 0.97 & \text { good } \\ 1.19 & \text { bad }\end{array}$

$\begin{array}{ll}1.07 & \text { very low } \\ 0.79 & \text { high } \\ 1.00 & \text { fairly high } \\ 0.83 & \text { high } \\ 0.76 & \text { high } \\ 1.00 & \text { fairly high } \\ 0.86 & \text { high } \\ 0.83 & \text { high } \\ 0.98 & \text { fairly high } \\ 0.88 & \text { high } \\ 1.03 & \text { low } \\ 0.93 & \text { high } \\ 1.10 & \text { very low } \\ 0.88 & \text { high } \\ 0.97 & \text { fairly high } \\ 1.19 & \text { very low }\end{array}$

UE Theology

UE Agriculture and environmental science

UE Mathematics and natural sciences

UE Construction and civil engineering

UE Mechanical engineering

UE Electrical engineering and inform. tech

UE Veterinary and medical sci. \& dentistry

UE Pharmacy

UE Economics, econom. and business adm.

UE Management science

UE Information science

UE Law

UE Public administration

UE Social sciences

bad

1.19

Source: ROA 
Appendix A 


\section{Appendix A Classification of economic sectors, occupational classes and types of education}

Table A.1

Economic sectors

Economic sector

SBI codes

Agriculture and fisheries

01-03

Food and beverage industry

20,21

Other industry

Chemicals

$22-27,32$

Metal and electrical industries

29-31

Energy

$33-39$

Construction

$11-19,28,40$

Commerce

$51,52,83$

Commerce

$61-66$

Other commercial services

$67,68,84,85,98,99$

Financial services

Non-commercial services

81,82

Civil service, police, defense and education

$91,93-97$

90,92

- The SBI classification allows for comparability with the classifications used in the ISIC (International Standard Industrial Classification of all economic activities) and NACE (Nomenclatura statistique des activités économiques dans la communauté européene) systems. 
Table A.2

Occupational classes

Occupational class

ROA code occupational groups

Educational occupations

Primary and special education teachers

Secondary and tertiary education teachers

School principals and other higher educational professions

Trainers, sports officials and sports professionals

\section{Cultural occupations}

Translators and other literary professions

Pastoral vocations

Photographers and designers

Visual and performing artists

Agricultural occupations

Agricultural workers

Farmers

Agricultural and environmental engineers

Technical and industrial occupations

Forklift drivers

Construction machine operators

Managers and supervisors in manufacturing

Technical and medical representatives

Technical draughtsmen

Technical analysts and laboratory assistants

Scientific researchers, technicians and statisticians

Food and beverage processors

Bakers and bakery personnel

Textile production workers

Upholsterers, shoemakers and leatherworkers

Clothing production workers and sailmakers

Wood, paper and cardboard product workers

Carpenters and woodworkers

Printing industry production workers

Chemical process workers

Smelter workers and drilling hands

Metal-processing machine operators

Welders and engineering workers

Lathe operators and metal workers

Machinery mechanics and instrument makers

Automobile mechanics

Intermediate mechanical engineers

Higher mechanical engineers

Elect. product assembly workers and quality controllers

Electricity and gas supply workers

Electricians and telecommunication servicemen

Intermediate electrical engineers

Higher electrical engineers

Ceramic and glass industry production workers

Bricklayers and plasterers

Glaziers and concreting hands

Painters
0131

0132

133

0221

$133,134,135$

131,132

139

180

$1131 \quad 195$

$1231 \quad 141,149$

$1321 \quad 162,163$

$1331 \quad 161,171-175,591$

2011

2012

2031

$621-624,629,632$

$601,602,609,611-613$,

631,680

053

3011

3012

979

$961,969,972-974$

$3021 \quad 024,028,211-214,701$,

$3022 \quad 461$

$3023 \quad 032$

$3024 \quad 014,036$

$3031 \quad 011-013,026,027,029$,

$051,052,081,082,085$

771-775, 777, 779,

$781-783$

776

$751-756,759,760$

$796,801-803$

$791-795,799$

$731-734,910$

$811,812,818,819,941$

$942,954,958$

$921-927,929$

$741-745,749$

$711-713,721-729$

$834-836,839,846,849$

$872,874,879,880$

$820,831-833,841,873$

$842,844,845$

843

$035,037,039,043$

025

$853,944,949$

857

$851,852,854-856,859,860$

034

023

891-894, 899, 901-902, 939, 943

951,955

$952,953,956,957$

931 
Table A.2 (continued)

Occupational classes

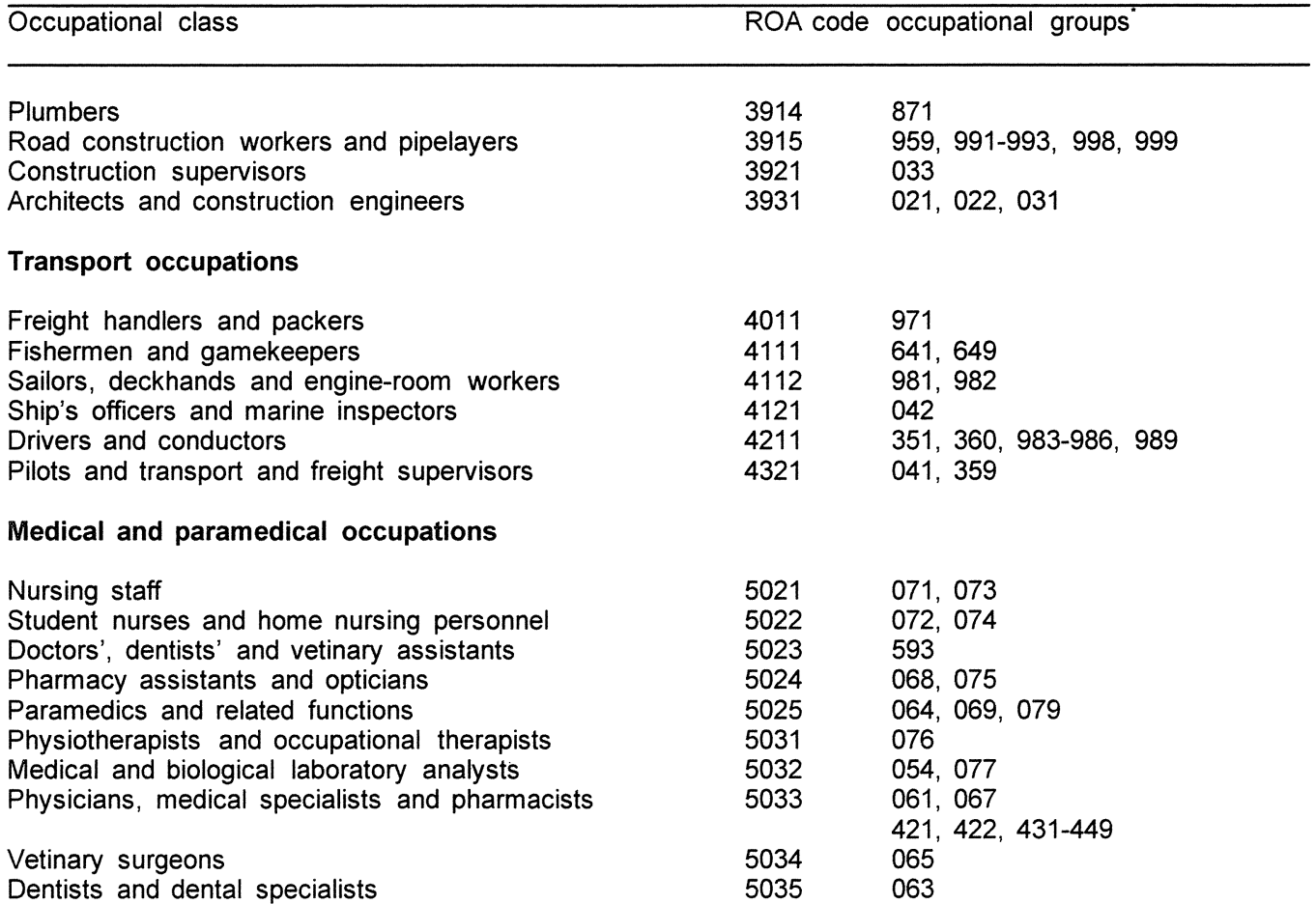

Commercial and administrative occupations

Senior finance and sales managers 6031

Mail clerks and postal workers 6111

Datatypists and computer operators 6112

Administrative supervisors $\quad 6121$

Secretaries and typists $\quad 6122$

Library and archive assistants 6123

Book-keepers and bank employees 6124

Purchasing and sales clerks $\quad 6125$

Telephonists, receptionists and pollsters 6126

Programmers and system analysts 6131

Accountants and economists $\quad 6132$

Sales assistants $\quad 6211$

Shopkeepers, retail and wholesale staff $\quad 6221$

Commercial representatives, buyers and branch managers 6222

Civil servants (public administration) 6331

Legal professionals 6332

\section{Socio-cultural occupations}

Journalists and announcers

Librarians and archivists

Personnel officers and vocational advisors

Community workers and probation officers

Social scientists

Public relations specialists

083, 084

090,110

$481,482,490$

$352,401,402,411,412$

$451,452,462,471-473$

201, 202, 310

$121,122,129$

Hotel, catering and service occupations

Cooks, waiters and kitchen workers 
Table A.2 (continued)

Occupational classes

Occupational class

ROA code occupational groups

Porters, cleaners and domestics

Geriatric help and kindergarten staff

8211

8212

$541,551,552,560,592,599$

Hairdressers and beauticians

8221

Public security and safety occupations

Police, fire and security officers

$9121 \quad 581,582,589$

Military professionals

9221

660

Comparable to the ISCO'88 classification. 
Table A.3

Types of education

\begin{tabular}{ll}
\hline Type of education & SOl codes
\end{tabular}

\section{Primary Education}

Primary Education

00000-20199

LGSE, PVE

Lower General Secondary Education

30100-30199

PVE Agriculture

PVE Construction trades

PVE Utilities installation

PVE Mechanical trades

PVE Automobile trades

PVE Electrical trades

32100-32999

$33610-33615, \quad 33617-33629$,

$33810-33815, \quad 33817-33829$

33616.33816

33630-33639

33641

33650-33659

33660-33669

33676,33677

$33673,33685,33873,33885$

PVE Textile and leather trades

PVE Transport and harbour

34100-34999

$36130-36139$

E Administration

36150-36159

38100-38999

PVE Community care, hotel and catering

39100-39499

\section{HGSE, IVE}

Higher General Secondary Education

$40100-40199$

IVE Agriculture and the natural environment

$42100-42999$

$43100-43199$

IVE Construction technolog

IVE Civil engineering

IVE Metalworking

IVE Precision engineering

IVE Mechanical engineering

IVE Automobile technology

IVE Electrical technology

IVE Printing technology

IVE Food technology

IVE Process technologies

IVE Textile and leather technology

IVE Transport and harbour

IVE Nursing and paramedical services

IVE Medical laboratory

IVE Retail

IVE Administration

IVE Tourism and recreation

43610-43619, 43810-43819

$43620-43629,43820-43829$

43630-43634, 43636-43639,

43830-43834, 43836-43839

43635,43835

$43640,43642-43649,43840$

$43842-43849$

43641,43841

$43650-43659, \quad 43850-43859$

43663-43668, 43863-43868

43676-43677, 43876-43877

43678, 43878

$43673,43685,43873,43885$

$44100-44999$

45100-45199, 45400-45499

48600-48699

$45200-45299$

$46138,46150-46180$

46133

46142

46148

46131, 45300-45399

IVE Secretarial

IVE Legal and fiscal

IVE Social and cultural

IVE Community care

IVE Hotel, catering and hairdressing

$46600-46699$

47100-47199

48100-48199, 48400-48499

IVE Police, fire and defense

48300-48399

49100-49499 
Table A.3 (continued)

Types of education

Type of education

SOI codes

\section{HVE}

HVE Teacher training

HVE Interpreter and translator

HVE Agriculture and environmental science

HVE Technical laboratory

HVE Construction and civil engineering

HVE Mechanical engineering

HVE Electronic and information technology

HVE Transport and harbour

HVE Medical laboratory

HVE Nursing and paramedical services

HVE Business administration

HVE Accounting

HVE Commercial information science

HVE Tourism and recreation

HVE Commerce

HVE Business administration technology

HVE Legal and fiscal

HVE Social and cultural

HVE Fine Arts

HVE Police, fire and defense

UE

UE Arts

UE Theology

UE Agriculture and environmental science

UE Mathematics and natural sciences

UE Construction and civil engineering

UE Mechanical engineering

UE Electrical engineering and information technology

UE Veterinary and medical sciences and dentistry

UE Pharmacy

UE Economics, econometrics and business admin.

UE Management science

UE Information science

UE Law

UE Public administration

UE Social sciences

UE Fine Arts
50600-50699, 60600-60699

$51100-51199$

$52100-52999$

$53100-53199$

$53610-53629,53810-53829$

53640-53649, 53840-53849

53650-53659

$54100-54999$

$55200-55299$

55100-55199, 55400-55499

56110

56133

56135

56142

56148

56200-56299

56600-56699

57100-57199

58600-58699

59100-59499

61100-61199, 70621-70623,

$70628,70666,71181$

$61600-61699,70627$

$62100-62999,72175,72220$

63100-63199, 70631-70639,

73100-73199

63610-63629, 63810-63829,

73618,73623

63640-63649, 63840-63849

63650-63659, 73651-73655

65100-65199, 70671, 75100-75199

65200-65299, 75200-75299

$66110,66133,66140-66148,66210$,

$66240,70661,76110,76120,76133$

$66120,66220,76220$

66135,76135

$66611-66619,76618$

66620-66699, 76620-76699

$67100-67199,70663$

68600-68699, 60680-60689,

70685-70688

An educational classification designed for the Dutch situation, but based on the ISCED system established by UNESCO. 